\title{
In Situ Physical/Chemical \\ Treatment Technologies for \\ Remediation of Contaminated Sites: \\ Applicability, Development Status, and Research Needs
}
R. L. Siegrist ${ }^{1}$
D. D. Gates ${ }^{1}$
O. R. West ${ }^{1}$

T. L. Donaldson ${ }^{2}$

L. Liang1

O. F. Webb ${ }^{2}$

S. L. Corder ${ }^{2}$

K. S. Dickerson ${ }^{3}$

Environmental Sciences Division

Publication No. 4238

Date Published: June 1994

Prepared for

U.S. DEPARTMENT OF ENERGY

Office of Technology Development

In Situ Remediation Integrated Program

Washington, D.C. 20585

Prepared By

OAK RIDGE NATIONAL LABORATORY

P.O. Box 2008

Oak Ridge, Tennessee 37830-6285

Managed by

MARTIN MARIETTA ENERGY SYSTEMS, INC. for the

U.S. DEPARTMENT OF ENERGY

Under Contract \#DE-AC05-84OR21400

1 Environmental Sciences Division, ORNL

2 Chemical Technology Division, ORNL

${ }^{3}$ Health Sciences Research Division, ORNL

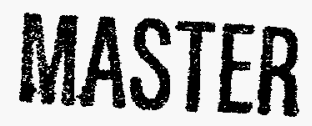




\section{DISCLAIMER}

This report was prepared as an account of work sponsored by an agency of the United States Government. Neither the United States Government nor any agency thereof, nor any of their employees, make any warranty, express or implied, or assumes any legal liability or responsibility for the accuracy, completeness, or usefulness of any information, apparatus, product, or process disclosed, or represents that its use would not infringe privately owned rights. Reference herein to any specific commercial product, process, or service by trade name, trademark, manufacturer, or otherwise does not necessarily constitute or imply its endorsement, recommendation, or favoring by the United States Government or any agency thereof. The views and opinions of authors expressed herein do not necessarily state or reflect those of the United States Government or any agency thereof. 


\section{DISCLAIMER}

Portions of this document may be illegible in electronic image products. Images are produced from the best available original document. 


\section{CONTENTS}

LIST OF FIGURES $\mathrm{v}$

LIST OF TABLES vi

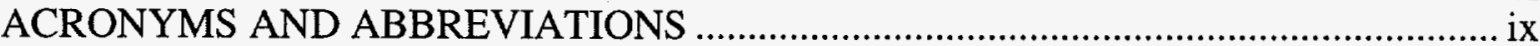

PREFACE $\mathrm{xi}$

ACKNOWLEDGMENTS xiii

EXECUTIVE SUMMARY

1.0 INTRODUCTION

1.1 PURPOSE AND SCOPE 1

1.2 APPROACH

2.0 ASSESSMENT OF DOE NEEDS 5

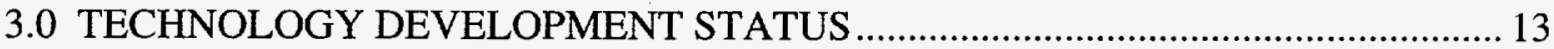

3.1 FEATURES OF ISPCT TECHNOLOGIES ............................................. 13

3.1.1 In Situ Contaminant-Transfer Processes.......................................... 13

3.1.2 In Situ Contaminant-Destruction Processes...................................... 15

3.1.3 In Situ Contaminant-Immobilization Processes................................ 15

3.2 STAGE OF DEVELOPMENT AND COMMERCIALIZATION ................... 16

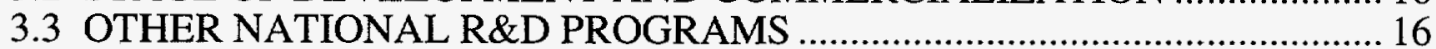

4.0 R\&D PROGRAM FOR ISPCT TECHNOLOGIES ….......................................... 23

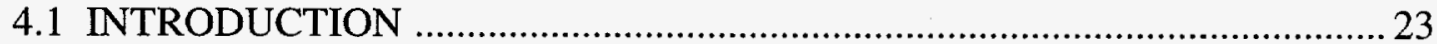

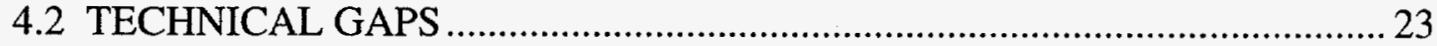

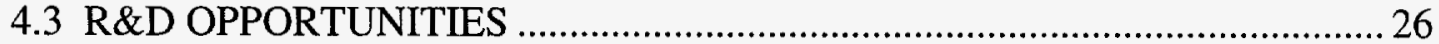

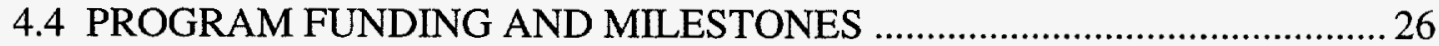

4.5 IMPACT OF UNRESOLVED ISSUES …............................................. 30

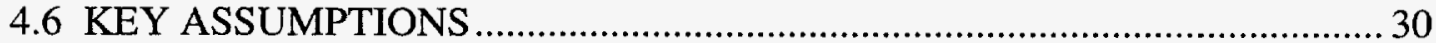

4.7 REGULATIONS AND REQUIREMENTS ........................................ 30

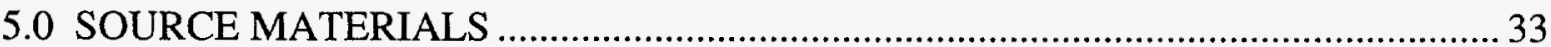

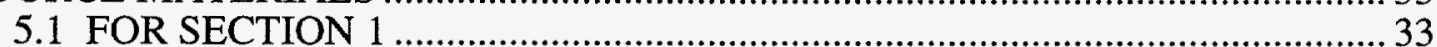

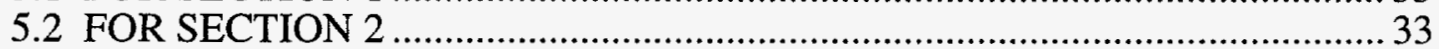

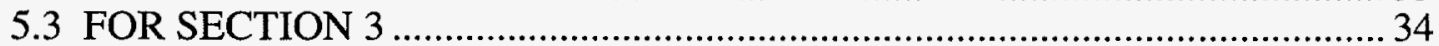

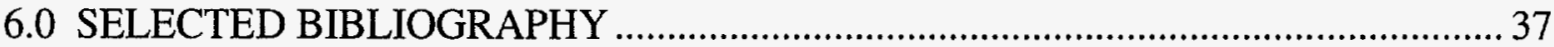

6.1 MISCELLANEOUS TECHNICAL PUBLICATIONS AND REPORTS ......... 37

6.2 PUBLICATIONS FROM RELEVANT FEDERALLY FUNDED

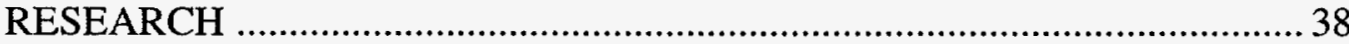

6.2.1 U. S. Department of Energy Published Reports.............................. 38

6.2.2 U. S. Environmental Protection Agency Published Reports................ 41

6.2.3 U. S. Air Force Published Reports .................................................. 42

6.2.4 U. S. Army Published Reports ................................................... 42

APPENDIX A: TECHNOLOGY DEVELOPMENT AND COMMERCIALIZATION .... 45

APPENDIX B: OTHER RELEVANT RESEARCH AND DEVELOPMENT

PROGRAMS. 



\section{LIST OF FIGURES}

$\underline{\text { Page }}$

4.1. Technology development stages and scope of ISPCT subarea........................... 24 


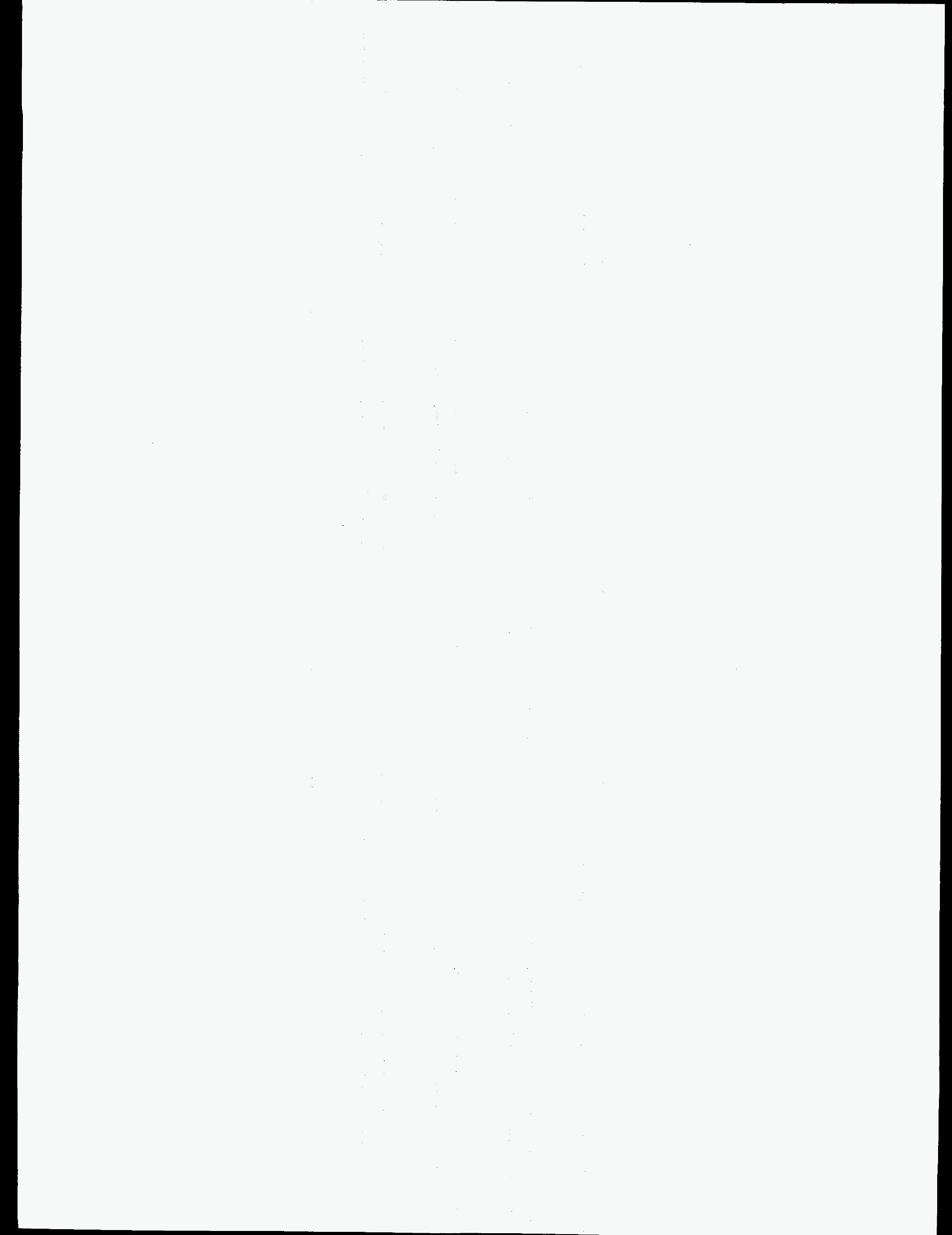




\section{LIST OF TABLES}

2.1. Physical and contamination conditions at selected DOE facilities 6

2.2. Prevalence of contaminants encountered at selected DOE facilities 9

2.3. ISPCT technology development framework of needs 11

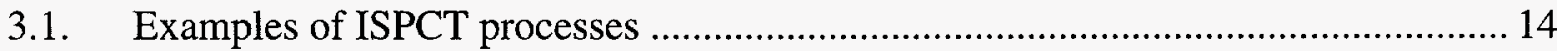

3.2. Assessed stage of the development and applicability of in situ contaminanttransfer processes for remediation of DOE sites

3.3. Assessed stage of the development and applicability of in situ contaminantdestruction processes for remediation of DOE sites

3.4. Assessed stage of the development and applicability of in situ contaminantimmobilization processes for remediation of DOE sites

3.5. Highlights of national R\&D programs with activities relevant to ISPCT technologies

4.1. Current and near-term gaps in technology development for ISPCT technologies ...25

4.2. Currently funded projects within the DOE ISR program that focus on ISPCT technologies

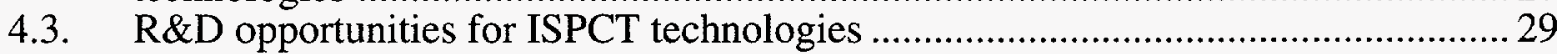

4.4. Program milestones for ISPCT technology R\&D ................................................. 31

A.1. Reported stage-of-development information for ISPCT technologies that rely on contaminant transfer processes

A.2. Reported stage-of-development information for ISPCT technologies that rely on destruction processes

A.3. Reported stage-of-development information for ISPCT technologies that rely on immobilization processes

B.1. U.S. Department of Energy physical/chemical funded research for in situ use (or applicable for in situ)

B.2. U.S. EPA Office Of Exploratory Research for 1991 and $1992 \ldots \ldots \ldots \ldots \ldots \ldots \ldots \ldots \ldots \ldots . . .59$

B.3. Superfund Innovative Technology Evaluation Program Demonstrations for 1991 and 1992

B.4. Emerging Technology Research and Development for 1991 and 1992 



\section{ACRONYMS AND ABBREVIATIONS}

\begin{tabular}{|c|c|}
\hline AFESC & - $\quad$ Air Force Engineering and Services Center \\
\hline ANL & - Argonne National Laboratory \\
\hline BNL & - Brookhaven National Laboratory \\
\hline CERCLA & $\begin{array}{l}\text { - Comprehensive Environmental Response Compensation } \\
\text { and Liability Act }\end{array}$ \\
\hline CRADA & - Cooperative Research and Development \\
\hline CROW & - Contaminated Recovery of Oily Wastes (CROW $\left.{ }^{\mathrm{TM}}\right)$ \\
\hline CT & - carbon tetrachloride \\
\hline DCA & - dichloroethane \\
\hline DCE & - dichloroethene \\
\hline DNAPLs & - dense, non-aqueous-phase liquids \\
\hline DOD & - U. S. Department of Defense \\
\hline DOE & - U. S. Department of Energy \\
\hline $\mathrm{EM}$ & $\begin{array}{l}\text { Office of Environmental Restoration and Waste } \\
\text { Management }\end{array}$ \\
\hline $\mathrm{EM}-40$ & - Office of Environmental Restoration within EM \\
\hline EM-50 & - Office of Technology Development within EM \\
\hline EPA & - U. S. Environmental Protection Agency \\
\hline EPRI & - Electric Power Research Institute \\
\hline ER & - Office of Environmental Restoration \\
\hline FEMP & - Fernald Environmental Management Project \\
\hline FMPC & - Feed Materials Production Center \\
\hline FY & - fiscal year \\
\hline GRI & - Gas Research Institute \\
\hline $\mathrm{HS}$ & - Hanford Site \\
\hline INEL & - Idaho National Engineering Laboratory \\
\hline IP & - Integrated Program (Office of Technology Development) \\
\hline ISPCT & - in situ physical/chemical treatment \\
\hline ISR & - in situ remediation \\
\hline $\mathrm{KCP}$ & - Kansas City Plant \\
\hline LLNL & - Lawrence Livermore National Laboratory \\
\hline LUST & - leaking underground storage tank \\
\hline MWLID & - $\quad$ Mixed Waste Landfill Integrated Demonstration \\
\hline NATO/CCMS & $\begin{array}{l}\text { North Atlantic Treaty Organization/Committee on } \\
\text { Challenges to Modern Society }\end{array}$ \\
\hline NSF & - National Science Foundation \\
\hline NTS & Nevada Test Site \\
\hline OER & Office of Energy Research \\
\hline ORNL & - Oak Ridge National Laboratory \\
\hline ORR & - Oak Ridge Reservation \\
\hline OTD & - Office of Technology Development \\
\hline PAD & - Paducah Gaseous Diffusion Plant \\
\hline $\mathrm{PAH}$ & - polycyclic aromatic hydrocarbon \\
\hline PCBs & - polychlorinated biphenyls \\
\hline PCE & - perchloroethylene (tetrachloroethene) \\
\hline PIN & - Pinellas Plant \\
\hline PNL & - Pacific Northwest Laboratory \\
\hline
\end{tabular}




\section{ACRONYMS AND ABBREVIATIONS (cont.)}

PORTS

PTX

R\&D

RCRA

RD\&D

RFP

RREL

SBIR

SITE

SNL

SRL

SVOC

TCA

TCE

TTP

USAEC

USAF

USATHAMA

UV

VISITT

VOC

WHC

WSRC
- Portsmouth Gaseous Diffusion Plant

- Pantex Plant

- research and development

- Resource Conservation and Recovery Act

- research, development and demonstration

- Rocky Flats Plant

- Risk Reduction Engineering Laboratory

- small business innovative research

- Superfund Innovative Technology Program

- Sandia National Laboratories

- Savannah River Laboratory

- semivolatile organic compound

- trichloroethane

- trichloroethene

- technical task plan

- U.S. Army Environmental Center

- U.S. Air Force

- U.S. Army Toxic and Hazardous Materials Agency (now the USAEC)

- ultraviolet

- Vendor Information System for Innovative Treatment Technologies

- volatile organic compound

- Westinghouse Hanford Corporation

- Westinghouse Savannah River Company 


\section{PREFACE}

The In Situ Remediation Integrated Program (ISR IP), instituted by the U. S. Department of Energy's Office of Technology Development, focuses research and development on the in-place treatment of contaminated environmental media, such as soil and groundwater, and the containment of contaminants to prevent the contaminants' spread through the environment. Using in situ technologies to clean up DOE sites minimizes adverse health effects to workers and the public by reducing contact exposure. The technologies also significantly reduce the costs for cleanup by eliminating the need for waste excavation, transport, and disposal; and enable the remediation of relatively inaccessible areas, such as the deep subsurface and areas beneath structures.

This document was prepared under the ISR IP and describes technologies in one of four program areas within the ISR IP. The four program areas are in situ physical/chemical treatment technologies, bioremediation, containment technologies, and in situ manipulation/enabling technologies. In situ physical/chemical treatment technologies address processes that will remove or extract, destroy, and immobilize contaminants. The bioremediation area includes biological processes to destroy organic contaminants and mobilize or immobilize heavy metals and radionuclides. Containment technologies encompass both surface and subsurface barriers, as well as sorbent or permeable barriers and drainage systems. The in situ manipulation/enabling technologies include those technologies that will enable the addition, mixing, and transfer of reagents or energy into the subsurface, and those that can be used to monitor and measure the performance of in situ technologies. These documents summarize the current state-of-the-art for each program area and the research and development requirements to advance the technologies to the point of demonstration and deployment. These documents will be used by the ISR IP as planning guides and will be revised and updated annually.

Information on the ISR IP can be obtained from:

Jeffrey S. Walker

Program Manager

U. S. Department of Energy (EM-53)

12800 Middlebrook Road

Germantown, MD 20874

(301) $903-7966$

or

Mary E. Peterson

Integrated Program Coordinator

Pacific Northwest Laboratory

Battelle

P.O. Box 999/MSIN K2-47

Richland, WA 99352

(509) 372-4655 



\section{ACKNOWLEDGMENTS}

This document was prepared as a planning guide for identifying in situ physical/chemical treatment processes applicable to various U. S. Department of Energy (DOE) needs, to summarize their development status, to identify ongoing research, and outline research needs. It is anticipated that this document will be revised and updated on an annual basis.

This document was prepared through the combined efforts of scientific and engineering staff at Oak Ridge National Laboratory (ORNL), with sponsorship provided by the In Situ Remediation Integrateed Program of the DOE Office of Technology Development. Mr. Jeffrey Walker, Program Manager, and Ms. Mary Peterson, Program Coordinator, are acknowledged for their guidance and oversight. Both internal and external peer reviewers are also acknowledged for their contributions.

\section{Contributors:}

R. L. Siegrist, Ph.D., P.E.

D. D. Gates, Ph.D.

O. R. West, Ph.D.

T. L. Donaldson, Ph.D., P.E.

L. Liang, Ph.D.

O. F. Webb, Ph.D.

S. L. Corder, B.Sc.

K. S. Dickerson, M.S.
Environmental Sciences Division, ORNL Environmental Sciences Division, ORNL Environmental Sciences Division, ORNL Chemical Technology Division, ORNL Environmental Sciences Division, ORNL Environmental Sciences Division, ORNL Chemical Technology Division, ORNL Health Sciences Research Division, ORNL

\section{Reviewers:}

R. E. Adams, M.S.

C. H. Brown, M.S

N. H. Cutshall, Ph.D.

C. W. Francis, Ph.D.

S. E. Herbes, Ph.D.

N. E. Korte, M. S.

J. J. Perona, Ph.D.

J. S. Watson, Ph.D.

J. Yow, Ph.D.
Hazardous Waste Remedial Actions Program, Martin Marietta Energy Systems, Inc.

Chemical Technology Division, ORNL

Office of Environmental Technology Development, Martin Marietta Energy Systems, Inc.

Environmental Sciences Division, ORNL Environmental Sciences Division, ORNL Environmental Sciences Division, ORNL Chemical Technology Division, ORNL Environmental Restoration Division, Martin Marietta Energy Systems, Inc.

Lawrence Livermore National Laboratory 


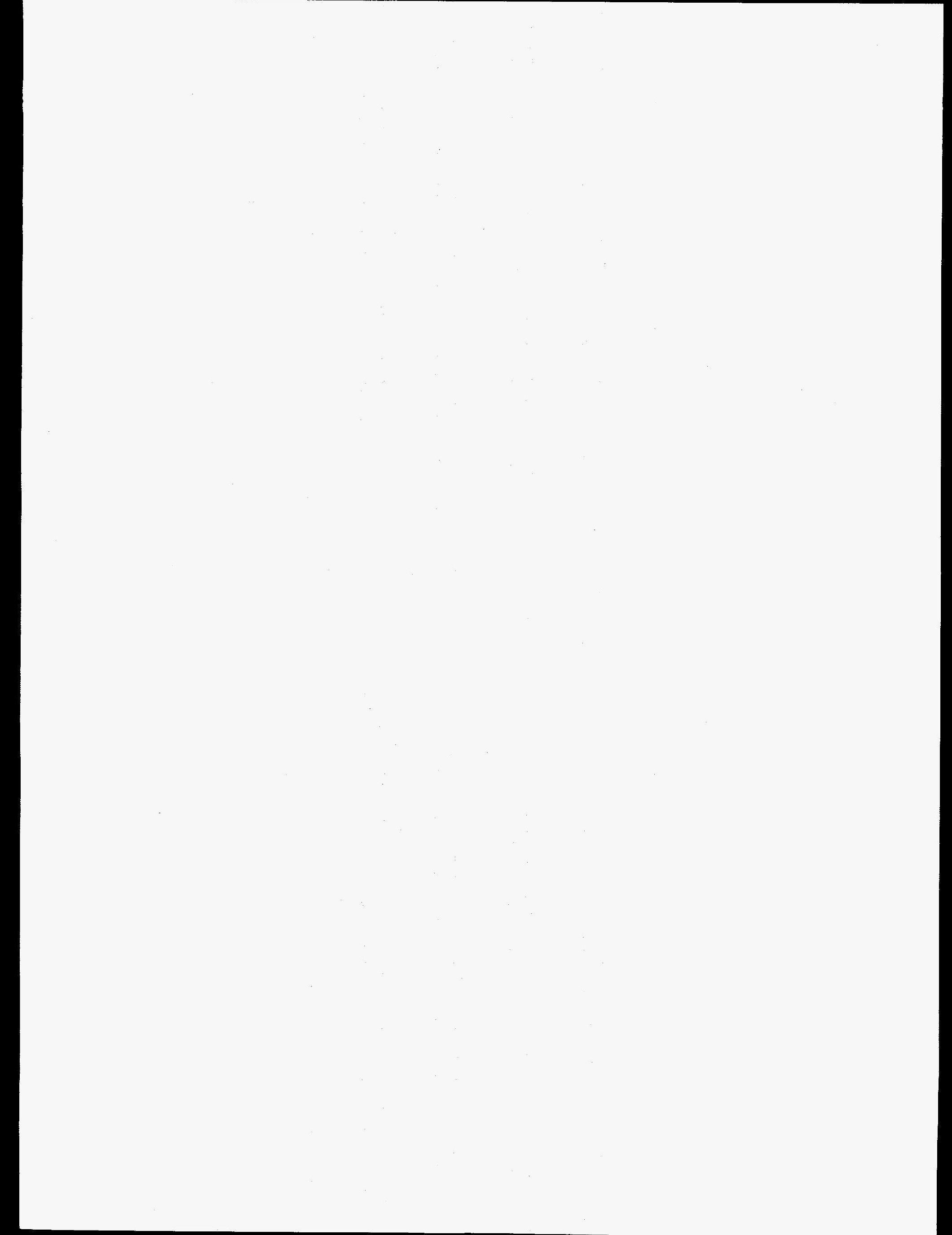




\section{EXECUTIVE SUMMARY}

The U. S. Department of Energy (DOE) In Situ Remediation Integrated Program (ISR IP) was established in June 1991 to facilitate the development and implementation of in situ remediation technologies for environmental restoration within the DOE complex. Within the ISR IP, four subareas of research have been identified: (1) in situ containment, (2) in situ physical/chemical treatment (ISPCT), (3) in situ bioremediation, and (4) subsurface manipulation/electrokinetics. Although set out as individual focus areas, these four are interrelated, and successful developments in one will often necessitate successful developments in another.

In situ remediation technologies are increasingly being sought for environmental restoration due to the potential advantages that in situ technologies can offer as opposed to more traditional ex situ technologies. These advantages include limited site disruption, lower cost, reduced worker exposure, and treatment at depth under structures. While in situ remediation technologies can offer great advantages, many technology gaps exist in their application. These include inadequate information, particularly at field scale, in the areas of performance potential, implementation constraints, limitations to applicability, and verification of performance. This document presents an overview of ISPCT technologies and describes their applicability to DOE-complex needs, their development status, and relevant ongoing research. It also highlights research needs that the ISR IP should consider when making funding decisions. Preparation of this document was accomplished through acquisition, review, and synthesis of a variety of information associated with DOE-complex needs and the stage of development of ISPCT technologies. This effort included an assessment of the physical conditions and site characteristics of specific DOE sites. The technology developmental status of ISPCT processes potentially applicable to DOE-complex needs was assessed through review of technical literature and personal inquiries, review of information sources regarding technology research and development (R\&D) activities, review of national $R \& D$ programs, and review of recent and ongoing $R \& D$ projects. The needs information was synthesized with the technology development status to enable identification of technical gaps and definition of the research needs for ISPCT within the ISR IP. It is envisioned that this report will be updated periodically to reflect $R \& D$ advances and necessary and appropriate changes in program objectives, scope, and schedule.

ISPCT processes can remediate subsurface contaminants without excavation of the contaminated soils or pumping of the groundwater. ISPCT involves additions to or alterations of the subsurface that change the physical and/or chemical properties of the subsurface environment. The contaminants of interest can either be treated in place or transferred to the surface via a secondary carrier phase for subsequent treatment. ISPCT processes can either be applied as an alternative to in situ biological processes or as preor post-treatment to facilitate bioremediation. ISPCT can be used in environments where microorganisms fail to thrive, can treat recalcitrant organic and inorganic compounds, and can accomplish treatment more rapidly and extensively than in situ bioremediation. 


\section{INTRODUCTION}

\subsection{PURPOSE AND SCOPE}

Contamination of soil and groundwater media by a wide variety of organic and inorganic substances is prevalent at commercial and industrial sites throughout the United States and abroad. At facilities within the U.S. Department of Energy (DOE) complex, contaminated land presents serious challenges to science and engineering due to the nature of the contamination and the complexity of the sites involved. In situ remediation (ISR) technologies are increasingly being sought for environmental restoration due to the potential advantages that ISR technologies can offer compared to more traditional ex situ technologies. These advantages include limited site disruption, lower cost, reduced worker exposure, lower secondary-waste generation, and treatment potential at depth or under obstructed sites.

The DOE In Situ Remediation Integrated Program (ISR IP) was established in June 1991 to facilitate the development and implementation of ISR technologies for environmental restoration within the DOE complex. According to the ISR IP strategic program plan, "ISR technologies shall contain, destroy, immobilize, recover, or neutralize contaminated soil, groundwater, or related environmental media" (DOE 1993). The ISR IP program includes research and development $(R \& D)$ from proof of concept through field demonstration.

In situ treatment processes can remediate subsurface contaminants without excavation of the contaminated soils or extraction of the groundwater. The contaminants of interest can be either treated in place or transferred to the surface via a secondary carrier phase for subsequent treatment. In this context, aboveground treatment of contaminated groundwater (a.k.a. pump and treat) is not considered an in situ treatment; however aboveground treatment of soil-sorbed contaminants (e.g., soil flushing) is considered part of an in situ treatment process.

Within the ISR IP, four subareas of research have been identified: (1) in situ containment, (2) in situ physical/chemical treatment (ISPCT), (3) in situ bioremediation, and (4) subsurface manipulation/electrokinetics (DOE 1993). While set out as individual focus areas, these four are obviously interrelated, and successful developments in one will often necessitate successful developments in another. Of the four focus areas, two are predominately contaminant treatment processes (i.e., in situ bioremediation and ISPCT), whereas the other two areas include techniques that can be used to minimize the impact of existing contamination or facilitate the application of in situ treatment processes. Biological treatment is most often used to degrade organic contaminants, although in situ biological processes to immobilize non-organic contaminants (metals, radionuclides, nitrates) are currently being developed. ISPCT can overcome many of the shortcomings encountered with in situ bioremediation. For example, ISPCT can be used in environments where microorganisms fail to thrive, can treat recalcitrant organic and inorganic compounds, and accomplish treatment more rapidly and extensively than in situ bioremediation. ISPCT processes can be applied either as an alternative to in situ biological treatment or as a pre- or post-treatment in conjunction with biological treatment. 
The overall goal of ISPCT research within the ISR IP should be to develop a portfolio of ISR technologies employing physical/chemical processes for treatment of contaminants in situations that are common at DOEE sites. These processes may be categorized as in situ contaminant transfer (e.g., extraction), destruction (e.g., chemical oxidation), or immobilization (e.g., microencapsulation) and may be employed individually or in combination with other processes to form an ISR technology. An example is the in situ treatment of dense, non-aqueous-phase liquids (DNAPLs), which may require temporary. containment during treatment followed by effective subsurface manipulation to deliver and disperse appropriate chemical and biological treatment agents.

The purpose of this document is to provide a foundation for establishing R\&D priorities for ISPCT of contaminated soil and groundwater within the ISR IP. No attempt was made to differentiate between soil treatment and groundwater treatment; rather, the needs of the DOE complex were evaluated as a whole. This report includes several elements: (1) an assessment of DOE needs for which ISPCT may be applicable, (2) a discussion of the stage of development of selected ISPCT processes and technologies, (3) a discussion of ongoing R\&D related to ISPCT, (4) identification of technical gaps that exist and for which ongoing R\&D will likely not provide solutions, and (5) recommendations for current priorities. This document is intended to be used as a source of information during DOE's planning process.

\subsection{APPROACH}

Preparation of this document was accomplished through acquisition, review, and synthesis of a variety of information associated with DOE-complex needs and the stage of development of ISPCT technologies. Complex-wide needs assessments and sitespecific technology logic diagrams were reviewed to gain a broad perspective of DOEcomplex needs and the perceived priority of in situ remediation technologies as stated by those actually responsible for implementing environmental restoration techrologies. This effort also included an assessment of the physical conditions and site characteristics of specific DOE sites. This type of site-specific review was deemed necessary to better define the contamination and physical conditions as related to the applicability of ISPCT technologies. The main sources for this information were the environmental reports issued annually by each facility in compliance with DOE orders. A synopsis of DOE contamination characteristics and an assessment of technology needs and constraints associated with application of ISPCT are given in Section 2.0.

The technology developmental status of ISPCT processes potentially applicable to DOEcomplex needs was assessed through the following means: (1) review of technical literature and personal inquiries, (2) review of information sources regarding technology R\&D activities in the United States and abroad, (3) review of national R\&D programs, and (4) review of recent and ongoing projects. The information from these sources was assimilated to yield an understanding of the development status of ISPCT technologies. A comprehensive technical discussion of each technology is beyond the scope of this document and may be found elsewhere in the literature. A synopsis of this effort is presented in Section 3.0. The needs information was synthesized with the technology development status to enable identification of technical gaps and definition of research needs for ISPCT within the ISR IP. Section 4.0 presents a description of the proposed research needs. 
This document represents the first edition covering ISPCT technologies within the ISR IP. It is intended that it will be updated periodically to reflect necessary and appropriate changes. R\&D needs with regard to in situ physical/chemical processes will change as projects are completed and progress is made. Priority needs will undoubtedly change as technologies become available for solving some environmental restoration problems. R\&D is currently being funded within the ISR IP. Additional R\&D will be funded in the years ahead. This existing and future work should be integrated to accomplish the objectives outlined in this report. 



\section{ASSESSMENT OF DOE NEEDS}

To enable examination of needs within the DOE complex for which ISPCT technologies may be applicable, it was necessary to define both the common contaminants and soil and groundwater conditions (Table 2.1). The most predominant sources of contamination at selected DOE sites appear to be the various liquid and solid-waste management units such as liquid-waste disposal facilities (e.g., land treatment units, surface impoundments, retention ponds, burning pits, and french drains) and buried waste deposits (e.g., pits, trenches, and landfills). A number of these waste management units have been "closed" under the Resource Conservation and Recovery Act (RCRA), with a closure strategy that included surface capping. However, since these were not clean closures, the facilities are required to monitor the groundwater surrounding the sites to ensure effectiveness of the cap in isolating the waste disposal unit. Other sources of contamination include leaking liquid-waste pipelines, high-use areas (areas surrounding waste treatment facilities, test firing sites) and leaking underground storage tanks (LUSTs). The latter do not seem to be causing wide-spread groundwater contamination in most facilities, only affecting soils surrounding tanks. Leachates from the land treatment units and burial sites have in many cases resulted in contamination of subsurface media, including soil and groundwater (Table 2.1). In addition, there are situations where contamination of surface-water sediments has occurred due to off-site releases.

Simple characterization of these contaminated media is precluded by the diversity of conditions encountered. In considering the priority of the problem, the potential environmental impact of contamination must be considered. In Table 2.1, wherever possible, the perceived environmental impact is provided. The prevalence of contaminants and mixtures are highlighted in Table 2.2. As shown, the most prevalent classes of contaminants are: (1) radionuclides, (2) chlorinated hydrocarbons [including volatile organic compounds (VOCs)], and (3) anions (specifically non-routine anions). Mixtures of contaminants are also very common (see Tables 2.1 and 2.2).

The problems and needs of the DOE complex are diverse and challenging for any remediation technology, including in situ technologies. Even though these challenges confront all remediation technologies, it is important to recognize that to be feasible and effective and to contribute to ER progress within the DOE complex, ISPCT must be developed and implemented within the framework of needs outlined in Table 2.3. As will be discussed in subsequent sections of this report, the above framework is applicable to ISPCT alone or in combination with other forms of in situ remediation. In fact, for many of the needs, ISPCT technologies represent the only viable form of remediation based on treatment. 
Table 2.1. Physical and contamination conditions at selected DOE facilities.

\begin{tabular}{|c|c|c|c|c|c|}
\hline $\begin{array}{l}\text { DOE } \\
\text { Facility }\end{array}$ & $\begin{array}{l}\text { Hydraulic } \\
\text { conductivity (K) of } \\
\text { subsurface materials } a\end{array}$ & $\begin{array}{l}\text { Site complexity } \\
\text { and heterogeneity }\end{array}$ & $\begin{array}{l}\text { Depth of } \\
\text { contamination }\end{array}$ & $\begin{array}{l}\text { Extensive areal } \\
\text { groundwater } \\
\text { contamination }^{b}\end{array}$ & $\begin{array}{l}\text { Environmental } \\
\text { impact }\end{array}$ \\
\hline ANL & $\begin{array}{l}\text { Low K layer (silty- } \\
\text { clay glacial till) } \\
\text { overlying high } \mathrm{K} \\
\text { zone (dolomite) }\end{array}$ & & $<30 \mathrm{~m}^{c}$ & & $\begin{array}{l}\text { Underlying } \\
\text { aquifer } \\
\text { (dolomite) is a } \\
\text { domestic water- } \\
\text { supply source. }\end{array}$ \\
\hline BNL & $\begin{array}{l}\text { High K zone } \\
\text { (sands) }\end{array}$ & & $<60 \mathrm{~m}^{c}$ & & $\begin{array}{l}\text { BNL is a } \\
\text { recharge area } \\
\text { for a "sole- } \\
\text { source aquifer." }\end{array}$ \\
\hline $\begin{array}{l}\text { FMPC/ } \\
\text { FEMP }\end{array}$ & $\begin{array}{l}\text { Low K layer (silty- } \\
\text { clay glacial till) } \\
\text { overlying high K } \\
\text { layer (sand and } \\
\text { gravel). Pockets of } \\
\text { clay exist in the high } \\
\text { K zone. }\end{array}$ & & $\sim 45 \mathrm{~m}^{d}$ & $\begin{array}{l}\text { U plume in Great } \\
\text { Miami aquifer }\end{array}$ & $\begin{array}{l}\text { Underlying } \\
\text { Great Miami } \\
\text { aquifer is a } \\
\text { water source for } \\
\text { local farms, } \\
\text { homes, and } \\
\text { businesses. }\end{array}$ \\
\hline HS & $\begin{array}{l}\text { High K layers }(600 \text { to } \\
3000 \mathrm{~m} / \mathrm{d} \text { ) separated } \\
\text { by low } \mathrm{K} \text { layers }(0.1 \\
\mathrm{m} / \mathrm{d})\end{array}$ & heterogeneous & $\sim 106 \mathrm{~m}^{e}$ & $\begin{array}{l}\mathrm{H}-3, \mathrm{Tc}-99, \mathrm{CCl}_{4}, \\
\text { DNAPL, } \\
\text { chloroform, } \\
\text { cyanide, nitrate } \\
\text { plumes }\end{array}$ & $\begin{array}{l}\text { Groundwater } \\
\text { seeps to } \\
\text { Columbia River. }\end{array}$ \\
\hline INEL & $\begin{array}{l}\text { Interbedded high } \mathrm{K} \\
\text { layers (sedimentary } \\
\text { deposits) and low } \mathrm{K} \\
\text { zones (basaltic rocks) }\end{array}$ & $\begin{array}{l}\text { complex fracture } \\
\text { flow in Snake } \\
\text { River Plain } \\
\text { aquifer }\end{array}$ & $\sim 270 \mathrm{~m}^{e}$ & $\begin{array}{l}\mathrm{H}-3, \mathrm{Sr}-90, \mathrm{Na} \text {, } \\
\text { nitrate plumes in } \\
\text { Snake River Plain } \\
\text { aquifer }\end{array}$ & $\begin{array}{l}\text { Snake River } \\
\text { Plain aquifer is } \\
\text { an important } \\
\text { water source in } \\
\text { southeastern } \\
\text { Idaho. }\end{array}$ \\
\hline $\mathrm{KCP}$ & $\begin{array}{l}\text { Low K zone }(0.3 \mathrm{~m} / \mathrm{d} ; \\
\text { sand-clay-silt) } \\
\text { overlying high K } \\
\text { layer (basal gravel) }\end{array}$ & & $<12 \mathrm{~m}^{c}$ & $\begin{array}{l}\text { TCE plume, } \\
\text { PCBs in soils }\end{array}$ & \\
\hline LLNL & $\begin{array}{l}\text { High } \mathrm{K} \text { zone } \\
(1 \text { to } 6 \mathrm{~m} / \mathrm{d})\end{array}$ & $\begin{array}{l}\text { heterogeneous, } \\
\text { interbedded } \\
\text { layers of clay, } \\
\text { silt, sand, and } \\
\text { gravel }\end{array}$ & $<119 \mathrm{~m}^{c}$ & VOC plume & \\
\hline $\begin{array}{l}\text { LLNL, } \\
\text { Site } \\
300\end{array}$ & $\begin{array}{l}\text { High K zones } \\
\text { (aquifers) in deep } \\
\text { underlying formation }\end{array}$ & $\begin{array}{l}\text { complex and very } \\
\text { heterogeneous }\end{array}$ & shallow & $\begin{array}{l}\text { TCE (DNAPL) } \\
\text { plume }\end{array}$ & $\begin{array}{l}\text { Drinking and } \\
\text { process water } \\
\text { obtained from } \\
\text { underlying } \\
\text { Neroly Lower } \\
\text { Blue Sandstone } \\
\text { aquifer. } \\
\end{array}$ \\
\hline
\end{tabular}


Table 2.1. Physical and contamination conditions at selected DOE facilities (continued).

\begin{tabular}{|c|c|c|c|c|c|}
\hline $\begin{array}{l}\text { DOE } \\
\text { Facility }\end{array}$ & $\begin{array}{l}\text { Hydraulic } \\
\text { conductivity (K) of } \\
\text { subsurface materials } a\end{array}$ & $\begin{array}{l}\text { Site complexity } \\
\text { and heterogeneity }\end{array}$ & $\begin{array}{l}\text { Depth of } \\
\text { contamination }\end{array}$ & $\begin{array}{l}\text { Extensive areal } \\
\text { groundwater } \\
\text { contamination } b\end{array}$ & $\begin{array}{l}\text { Environmental } \\
\text { impact }\end{array}$ \\
\hline NTS & $\begin{array}{l}\text { Low to high K zone } \\
\text { ( } 0.02 \text { to } 1 \mathrm{~m} / \mathrm{d} \\
\text { estimated from } \\
\text { transmissivity and } \\
\text { thickness of the } \\
\text { Valley Fill aquifer) } \\
\text { overlying high } \mathrm{K} \\
\text { zone (carbonate) }\end{array}$ & & & $\begin{array}{l}\text { Areally extensive } \\
\mathrm{H}-3, \mathrm{Pu} \text { in soil }\end{array}$ & $\begin{array}{l}\text { Potential for } \\
\text { migration of } \mathrm{Pu}- \\
\text { contaminated } \\
\text { soils. }\end{array}$ \\
\hline ORR & $\begin{array}{l}\text { Low K zones }(<0.1 \\
\mathrm{m} / \mathrm{d})\end{array}$ & $\begin{array}{l}\text { heterogeneous } \\
\text { fracture flow with } \\
\text { matrix diffusion }\end{array}$ & $150 \mathrm{~m}^{d}$ & $\begin{array}{l}\text { Nitrate and } \\
\text { VOC (DNAPL) } \\
\text { plumes }\end{array}$ & $\begin{array}{l}\text { Potential } \\
\text { migration of } \\
\text { radioactive } \\
\text { contaminants } \\
\text { through shallow } \\
\text { subsurface } \\
\text { storm flow to } \\
\text { the Clinch } \\
\text { River. }\end{array}$ \\
\hline PAD & $\begin{array}{l}\text { High } \mathrm{K} \text { zones }(4 \mathrm{~m} / \mathrm{d}) \\
\text { interbedded in low } \mathrm{K} \\
\text { zones }\left(10^{-6} \mathrm{~m} / \mathrm{d}\right) ; \\
\text { underlying high } \mathrm{K} \\
\text { zone (regional gravel } \\
\text { aquifer) }\end{array}$ & heterogeneous & $<60 \mathrm{~m}^{e}$ & $\begin{array}{l}\text { TCE (DNAPL), } \\
\text { Tc-99 plumes in } \\
\text { regional gravel } \\
\text { aquifer }\end{array}$ & $\begin{array}{l}\text { A number of } \\
\text { residences use } \\
\text { water from the } \\
\text { regional gravel } \\
\text { aquifer for } \\
\text { domestic and } \\
\text { agricultural } \\
\text { purposes. } \\
\end{array}$ \\
\hline PTX & $\begin{array}{l}\text { High K } \\
\text { zones(aquifers) in } \\
\text { deep underlying } \\
\text { formations }\end{array}$ & heterogeneous & $\sim 100 \mathrm{~m}^{d}$ & & $\begin{array}{l}\text { Overlies the } \\
\text { Ogallala aquifer, } \\
\text { which is a } \\
\text { principal water } \\
\text { supply on the } \\
\text { high plains. }\end{array}$ \\
\hline PIN & $\begin{array}{l}\text { High K zone (shelly } \\
\text { sands) }\end{array}$ & & $<27 \mathrm{~m}^{c}$ & & $\begin{array}{l}\text { Overlies the } \\
\text { Floridan aquifer } \\
\text { which is a water } \\
\text { source for } \\
\text { Pinellas County. }\end{array}$ \\
\hline PORTS & $\begin{array}{l}\text { Low } \mathrm{K} \text { zones }\left(10^{-4} \text { to }\right. \\
\left.10^{-3} \mathrm{~m} / \mathrm{d}\right) \text { separating } \\
\text { high } \mathrm{K} \text { zones }(1 \mathrm{~m} / \mathrm{d})\end{array}$ & & $<30 \mathrm{~m}^{d}$ & $\begin{array}{l}\text { TCE plume in the } \\
\text { Gallia Sand }\end{array}$ & \\
\hline RFP & $\begin{array}{l}\text { Low K zone }\left(10^{-2}\right. \\
\mathrm{m} / \mathrm{d})\end{array}$ & & $<30 \mathrm{~m}^{d}$ & $\begin{array}{l}\text { TCE and } \\
\text { radionuclide (U) } \\
\text { plume }\end{array}$ & \\
\hline
\end{tabular}


Table 2.1. Physical and contamination conditions at selected DOE facilities (continued).

\begin{tabular}{|c|c|c|c|c|c|}
\hline $\begin{array}{l}\text { DOE } \\
\text { Facility }\end{array}$ & $\begin{array}{l}\text { Hydraulic } \\
\text { conductivity (K) of } \\
\text { subsurface materials } a\end{array}$ & $\begin{array}{l}\text { Site complexity } \\
\text { and heterogeneity }\end{array}$ & $\begin{array}{l}\text { Depth of } \\
\text { contamination }\end{array}$ & $\begin{array}{l}\text { Extensive areal } \\
\text { groundwater } \\
\text { contamination } b\end{array}$ & $\begin{array}{l}\text { Environmental } \\
\text { impact }\end{array}$ \\
\hline SNL & $\begin{array}{l}\text { Low to high } K \text { zone } \\
(0.001 \text { to } 1 \mathrm{~m} / \mathrm{d})\end{array}$ & $\begin{array}{l}\text { complicated by } \\
\text { fault blocks }\end{array}$ & $>150 \mathrm{~m}^{e}$ & TCE plume & \\
\hline SRL & $\begin{array}{l}\text { Low } \mathrm{K} \text { zones }\left(10^{-5} \text { to }\right. \\
10^{-2} \mathrm{~m} / \text { day) } \\
\text { interbedded with high } \\
\mathrm{K} \text { zones }(0.2 \text { to } 10 \\
\mathrm{m} / \text { day) }\end{array}$ & heterogeneous & $<30 \mathrm{~m}^{d}$ & $\begin{array}{l}\text { TCE (DNAPL) } \\
\text { and nitrate/H-3 } \\
\text { plumes }\end{array}$ & $\begin{array}{l}\text { Groundwater } \\
\text { discharges to } \\
\text { Savannah River. }\end{array}$ \\
\hline \multicolumn{6}{|c|}{$\begin{array}{l}\text { Information was derived from recent site environmental monitoring reports as listed in the source } \\
\text { materials (Sect 5) }\end{array}$} \\
\hline \multicolumn{5}{|c|}{$a$ Zones with $\mathrm{K}$ values less than $1 \mathrm{~m} / \mathrm{d}\left(1.1 \times 10^{-3} \mathrm{~cm} / \mathrm{s}\right)$ are considered as low permeability zones. } & zones. \\
\hline \multicolumn{2}{|c|}{$b$ If $\mathrm{K}$ values are unavailable, the conductivity is inferred from the aquifer material type. } & & & & \\
\hline \multicolumn{6}{|c|}{$c$ Depth of contamination based on the depth to the base of the contaminated hydrogeologic zone. } \\
\hline \multicolumn{6}{|c|}{$d$ Depth of contamination based on the depth of groundwater monitoring wells. } \\
\hline
\end{tabular}


Table 2.2. Prevalence of contaminants encountered at selected DOE facilities.

\begin{tabular}{|c|c|c|c|c|c|c|c|}
\hline $\begin{array}{c}\text { DOE } \\
\text { facility }\end{array}$ & $\begin{array}{c}\text { Predominant } \\
\text { class of } \\
\text { contaminants }\end{array}$ & $\begin{array}{c}\text { Contaminant } \\
\text { mixtures }\end{array}$ & $\begin{array}{c}\text { Chlorinated } \\
\text { hydrocarbons }\end{array}$ & $\begin{array}{c}\text { Fuel } \\
\text { hydrocarbons }\end{array}$ & Radionuclides & Anions & Metals \\
\hline ANL & $\begin{array}{l}\text { Chlorinated } \\
\text { hydrocarbons, } \\
\text { radionuclides }\end{array}$ & & $\begin{array}{l}\text { TCA, } \\
1,1-\mathrm{DCA}, \\
\text { TCE }\end{array}$ & & $\begin{array}{l}\mathrm{H}-3 \\
\mathrm{Sr}-90\end{array}$ & $\mathrm{Cl}$ & $\begin{array}{l}\mathrm{Cr}, \\
\mathrm{Cu}, \\
\mathrm{Fe}, \\
\mathrm{Mn}, \\
\mathrm{Pb}, \mathrm{As} \\
\end{array}$ \\
\hline $\mathrm{BNL}$ & $\begin{array}{l}\text { Chlorinated } \\
\text { hydrocarbons }\end{array}$ & $\begin{array}{l}\text { Chlorinated } \\
\text { hydrocarbons/ } \\
\text { fuel } \\
\text { hydrocarbons; } \\
\text { chlorinated } \\
\text { hydrocarbons/ } \\
\text { radionuclides }\end{array}$ & $\begin{array}{l}\text { TCA, } \\
\text { PCE, } \\
\text { TCE }\end{array}$ & $\begin{array}{l}\text { benzene, } \\
\text { toluene, } \\
\text { xylene, } \\
\text { ethylbenzene }\end{array}$ & Sr-90 & & $\mathrm{Fe}$ \\
\hline $\begin{array}{l}\text { FMPC/ } \\
\text { FEMP }\end{array}$ & Radionuclides & $\begin{array}{l}\text { Radionuclides/ } \\
\text { metals/ } \\
\text { chlorinated } \\
\text { hydrocarbons }\end{array}$ & $\begin{array}{l}\text { DCE, } \\
\text { TCE }\end{array}$ & $\begin{array}{l}\text { benzene, } \\
\text { xylene }\end{array}$ & $\begin{array}{l}\text { U, } \\
\text { Th, } \\
\text { Ra, } \\
\text { Tc-99, Sr-90 } \\
\end{array}$ & $\mathrm{SO}_{4}$ & $\begin{array}{l}\mathrm{Ba}, \\
\mathrm{Ca}, \\
\mathrm{Mg}, \\
\mathrm{Cd}\end{array}$ \\
\hline HS & $\begin{array}{l}\text { Radionuclides, } \\
\text { chlorinated } \\
\text { hydrocarbons, } \\
\text { anions }\end{array}$ & $\begin{array}{l}\text { Radionuclides/ } \\
\text { anions/ } \\
\text { chlorinated } \\
\text { hydrocarbons }\end{array}$ & $\begin{array}{l}\mathrm{CCl}_{4} \\
\text { (DNAPL), } \\
\text { chloroform }\end{array}$ & & $\begin{array}{l}\text { Tc-99, } \\
\text { Pu, U, H-3, } \\
\text { Sr, Co, I-129 }\end{array}$ & $\mathrm{NO}_{3}$ & $\mathrm{Cr}$ \\
\hline INEL & $\begin{array}{l}\text { Radionuclides, } \\
\text { anions }\end{array}$ & $\begin{array}{l}\text { Radionuclides/ } \\
\text { anions/ } \\
\text { chlorinated } \\
\text { hydrocarbons/ } \\
\text { metals } \\
\end{array}$ & $\begin{array}{l}\mathrm{CCl}_{4}, \\
1,1,1-\mathrm{TCA}, \\
\text { TCE, } \\
\text { PCE }\end{array}$ & $\begin{array}{l}\text { toluene, } \\
\text { benzene }\end{array}$ & $\begin{array}{l}\text { H-3, } \\
\text { Co-60, } \\
\text { Cs-137 }\end{array}$ & $\begin{array}{l}\mathrm{SO}_{4} \\
\mathrm{Cl}, \\
\mathrm{NO}_{3}\end{array}$ & $\begin{array}{l}\mathrm{Cr} \\
\mathrm{Na}\end{array}$ \\
\hline $\mathrm{KCP}$ & $\begin{array}{l}\text { Chlorinated } \\
\text { hydrocarbons, } \\
\text { PCBs }\end{array}$ & $\begin{array}{l}\text { Chlorinated } \\
\text { hydrocarbons/ } \\
\text { PCBs } \\
\end{array}$ & $\begin{array}{l}\text { TCE, } \\
\text { 1,2-DCE, } \\
\text { chloroethane } \\
\end{array}$ & benzene & & & \\
\hline LLNL & $\begin{array}{l}\text { Chlorinated } \\
\text { hydrocarbons }\end{array}$ & & $\begin{array}{l}\text { TCE, } \\
\text { PCE, } \\
1,1,1-\mathrm{TCA}, \\
\mathrm{CCl}_{4}, \\
\text { chloroform } \\
\end{array}$ & NSH & & & \\
\hline $\begin{array}{l}\text { LLNL, } \\
\text { Site } 300\end{array}$ & $\begin{array}{l}\text { Chlorinated } \\
\text { hydrocarbons }\end{array}$ & & $\begin{array}{l}\text { TCE } \\
\text { (DNAPL) }\end{array}$ & & & & \\
\hline NTS & Radionuclides & & & & $\begin{array}{l}\mathrm{H}-3, \mathrm{Pu}-238, \\
\mathrm{Pu}-239\end{array}$ & & \\
\hline ORR & $\begin{array}{l}\text { Radionuclides, } \\
\text { anions, } \\
\text { chlorinated } \\
\text { hydrocarbons }\end{array}$ & $\begin{array}{l}\text { Radionuclides/ } \\
\text { anions/ } \\
\text { chlorinated } \\
\text { hydrocarbons }\end{array}$ & $\begin{array}{l}\text { TCE } \\
\text { (DNAPL), } \\
\text { PCE, CCl } 4 \text {, } \\
1,2-\mathrm{DCE} \text {, } \\
1,1,1-\mathrm{TCA}, \\
\text { chloroform } \\
\end{array}$ & NSH & $\begin{array}{l}\text { U, } \\
\mathrm{H}-3, \\
\mathrm{Tc}, \\
\mathrm{Ra}, \\
\mathrm{Np}, \mathrm{Am}, \\
\text { Sr, Co } \\
\end{array}$ & $\mathrm{NO}_{3}$ & $\begin{array}{l}\mathrm{Hg}, \\
\mathrm{As}, \\
\mathrm{Ba}, \\
\mathrm{Cd}, \\
\mathrm{Cr}, \\
\mathrm{Pb}, \mathrm{Ni}\end{array}$ \\
\hline
\end{tabular}

The information shown was derived from recent site environmental monitoring reports among those listed as source materials in Sect. 5.

NSH: Non-specified hydrocarbons. 
Table 2.2. Prevalence of contaminants encountered at selected DOE facilities (continued).

\begin{tabular}{|c|c|c|c|c|c|c|c|}
\hline $\begin{array}{c}\text { DOE } \\
\text { facility }\end{array}$ & $\begin{array}{c}\text { Predominant } \\
\text { class of } \\
\text { contaminants }\end{array}$ & $\begin{array}{c}\text { Contaminant } \\
\text { mixtures }\end{array}$ & $\begin{array}{c}\text { Chlorinated } \\
\text { hydrocarbons }\end{array}$ & $\begin{array}{c}\text { Fuel } \\
\text { hydrocarbons }\end{array}$ & Radionuclides & Anions & Metals \\
\hline PAD & $\begin{array}{l}\text { Chlorinated } \\
\text { hydrocarbons, } \\
\text { radionuclides }\end{array}$ & $\begin{array}{l}\text { Chlorinated } \\
\text { hydrocarbons/ } \\
\text { radionuclides } \\
\end{array}$ & $\begin{array}{l}\text { TCE } \\
\text { (DNAPL) }\end{array}$ & & Tc-99 & & \\
\hline PTX & $\begin{array}{l}\text { Chlorinated } \\
\text { hydrocarbons, } \\
\text { radionuclides }\end{array}$ & & $\begin{array}{l}\text { TCE, } \\
1,2-\mathrm{DCA}\end{array}$ & & U-238 & & $\mathrm{Cr}$ \\
\hline PIN & $\begin{array}{l}\text { Chlorinated } \\
\text { hydrocarbons }\end{array}$ & & VOCs & & & & \\
\hline PORTS & $\begin{array}{l}\text { Chlorinated } \\
\text { hydrocarbons }\end{array}$ & $\begin{array}{l}\text { Chlorinated } \\
\text { hydrocarbons/ } \\
\text { radionuclides }\end{array}$ & $\begin{array}{l}\text { TCE, } \\
1,1,1-\mathrm{TCA}, \\
1,1-\mathrm{DCE} \text {, } \\
\mathrm{CCl} 4 \text {, } \\
\text { chloroform }\end{array}$ & & $\begin{array}{l}\text { Tc-99, } \\
\text { U }\end{array}$ & & \\
\hline RFP & $\begin{array}{l}\text { Radionuclides, } \\
\text { chlorinated } \\
\text { hydrocarbons }\end{array}$ & $\begin{array}{l}\text { Radionuclides/ } \\
\text { chlorinated } \\
\text { hydrocarbons }\end{array}$ & $\begin{array}{l}\text { TCE, } \\
\text { PCE, } \\
\mathrm{CCl}_{4}\end{array}$ & & $\begin{array}{l}\text { U, } \\
\text { Cs-137, } \\
\text { Am, } \\
\text { Pu, } \\
\text { Ra }\end{array}$ & & $\begin{array}{l}\mathrm{Cr}, \\
\mathrm{Li}, \\
\mathrm{K}, \\
\mathrm{Sr}, \\
\mathrm{Mn}, \\
\mathrm{Na}, \\
\mathrm{As}, \\
\mathrm{Ni}, \\
\mathrm{Se}, \\
\mathrm{Zn}, \\
\mathrm{Cu}, \\
\mathrm{Fe}, \\
\mathrm{Mg}\end{array}$ \\
\hline SNL & $\begin{array}{l}\text { Chlorinated } \\
\text { hydrocarbons }\end{array}$ & & TCE & & & & $\mathrm{Hg}$ \\
\hline SRL & $\begin{array}{l}\text { Chlorinated } \\
\text { organic } \\
\text { compounds, } \\
\text { radionuclides }\end{array}$ & $\begin{array}{l}\text { Radionuclides/ } \\
\text { anions }\end{array}$ & $\begin{array}{l}\text { TCE, PCE, } \\
\text { CCl } 4 \\
\text { (DNAPL) }\end{array}$ & & $\begin{array}{l}\mathrm{Ra}, \\
\mathrm{U}, \\
\mathrm{H}-3\end{array}$ & $\begin{array}{l}\mathrm{NO}_{3} \\
\mathrm{SO}_{4}\end{array}$ & $\begin{array}{l}\mathrm{Pb} \\
\mathrm{Hg}\end{array}$ \\
\hline
\end{tabular}

The information shown was derived from recent site environmental monitoring reports among those listed as source materials in Sect. 5.

NSH: Non-specified hydrocarbons. 
Table 2.3. Needs framework for ISPCT technology development.

\section{Site physical conditions}

Low subsurface hydraulic conductivity (e.g., silts and clays)

Substantial site complexity and heterogeneity (e.g., interbedded and fractured media)

Deep and vertically extensive contaminated regions (e.g., $53 \mathrm{~m}$ )

Relatively extensive areal regions of contamination (e.g., mile-long plumes)

Sites obstructed by surface and subsurface features (e.g., utilities, roads, buildings)

\section{Contaminants of key concern}

Mixtures of low-level radioactive substances (e.g., U, Tc) and hazardous volatile organic compounds (e.g., TCE, TCA, MC, CT)

Radioactive isotopes (e.g., H-3, Sr-90, Cs-137)

DNAPLs (e.g., TCE, PCE)

Hazardous heavy metals (e.g., $\mathrm{Hg}, \mathrm{Cr}, \mathrm{Pb}$ )

Hazardous organic compounds that are more refractory (e.g., PCBs)

\section{General technology features}

In situ processes that are proven in the field and able to reliably achieve desired performance

Technologies conducive to monitoring and process control and performance verification

In situ processes that are less costly than ex situ processes 


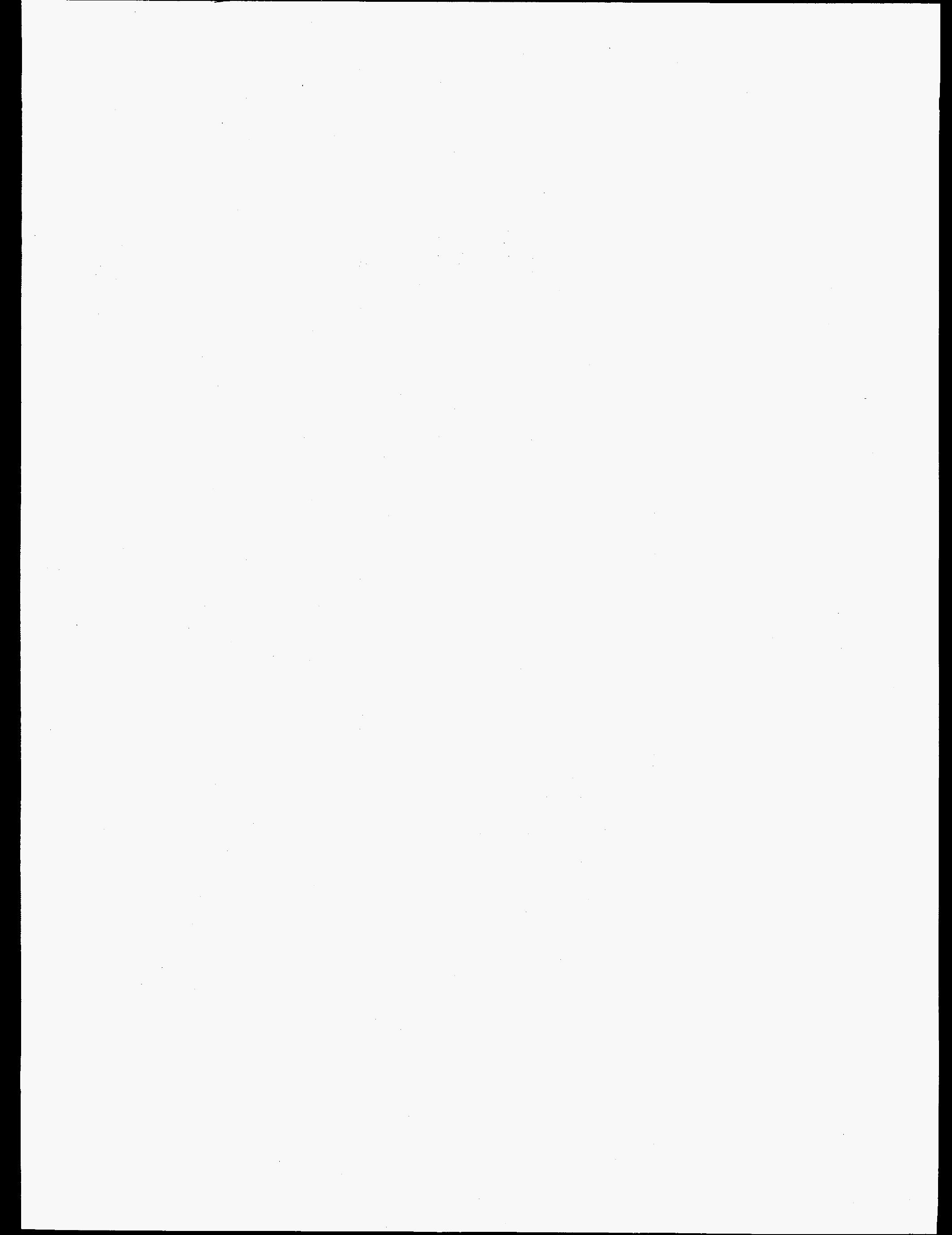




\section{TECHNOLOGY DEVELOPMENT STATUS}

\subsection{FEATURES OF ISPCT TECHNOLOGIES}

ISPCT involve additions to or alterations of the subsurface that change the physical and/or chemical properties of the subsurface environment. In response, the contaminants of concern are either transferred to another waste stream for subsequent treatment, destroyed and/or rendered non-toxic, or immobilized in a dispersed, stabilized matrix that isolates contaminants and prevents further subsurface migration. The subsurface can be physically manipulated using processes such as heating, freezing, mixing, or fracturing. Chemical properties that can be altered include $\mathrm{pH}$, ionic strength, oxidation-reduction (redox) potential, and chemical equilibria. Excellent reviews of in situ physical/chemical processes have been published previously (e.g., Handbook of In Situ Treatment of Hazardous Waste-Contaminated Soils, EPA 1990 and The Superfund Innovative Technology Evaluation Program: Technology Profile Fifth Edition, EPA 1992). For the purposes of this report, brief descriptions of the ISPCT processes are given below, while a summary of physical/chemical treatment processes with realized or potential application for in situ remediation within the DOE complex is given in Table 3.1. Many of the technologies listed in Table 3.1 are in either the conceptual or bench-scale stage. It should be noted that success at these scales does not always translate to success in the field because of site heterogeneities and complexities.

\subsubsection{In Situ Contaminant-Transfer Processes}

The ultimate objective of physical/chemical, in situ contaminant-transfer processes is to transfer the contaminant(s) of concern from the host matrix (soil or groundwater) to a secondary or carrier phase that can be retrieved and further processed. The carrier can be a gas phase such as air or steam, as is the case with volatilization processes. Volatilization processes are applicable to organic compounds with relatively high vapor pressures. Injection and extraction wells are often placed in the zone of contamination to facilitate volatilization. In some cases, a vacuum is applied to the extraction wells or at the surface to increase natural air flow through the contaminated medium (vacuum extraction), while in other instances clean air is pumped through contaminated groundwater (air sparging) to increase the transfer of VOCs to the gas phase. Thermal enhancement of volatilization processes include mechanisms to heat soils (e.g., microwave, radio-frequency heating) to increase the rate of volatilization of contaminants into the carrier phase. Once off-gases containing volatilized organic compounds are collected aboveground, the contaminants can then be destroyed or treated for disposal.

An aqueous carrier matrix is used with in situ soil flushing or leaching processes. In general, soil flushing is achieved by injecting water into the contaminated soil and collecting the water in extraction wells located adjacent to the treated area. Reagents can be added to the carrier water, such as surfactants to increase organic compound solubilization in the carrier phase or chelating agents to increase metals mobilization and collection. In some instances, the addition of either acidic or basic aqueous solutions is sufficient to facilitate the transfer of the contaminants of interest into the carrier phase. A somewhat related in situ physical/chemical process is electrokinetic separation. A subsurface electrical field is established to enhance the migration of charged contaminant species to implanted electrodes, where they can be collected with pore fluids. If 
Table 3.1. Examples of ISPCT processes.

\begin{tabular}{|c|c|}
\hline Treatment process area ${ }^{a}$ & Representative technology \\
\hline \multicolumn{2}{|l|}{ In Situ Transfer Processes } \\
\hline Volatilization/solvation & $\begin{array}{l}\text { Air sparging } \\
\text { Vacuum extraction } \\
\text { Hot air or steam extraction } \\
\text { Thermally enhanced } \\
\text { a. microwave } \\
\text { b. radio frequency } \\
\text { Supercritical fluids }\end{array}$ \\
\hline Adsorption & $\begin{array}{l}\text { Granular activated carbon } \\
\text { Zeolites } \\
\text { Organic sorbents }\end{array}$ \\
\hline Leaching & $\begin{array}{l}\text { Surfactants } \\
\text { Chelating agents } \\
\text { Acids or bases } \\
\end{array}$ \\
\hline Combinations of transfer processes & $\begin{array}{l}\text { Reactive membranes } \\
\text { Saponification } \\
\text { Washing and adsorption }\end{array}$ \\
\hline $\begin{array}{l}\text { Ion exchange } \\
\text { Electrokinetics } \\
\text { Constructed wetlands }\end{array}$ & Zeolites \\
\hline \multicolumn{2}{|l|}{ In Situ Destruction Processes } \\
\hline Chemical oxidation-reduction & $\begin{array}{l}\text { Hydrogen peroxide } \\
\text { Ozone } \\
\text { Potassium permanganate } \\
\text { Solvated electrons } \\
\text { Chlorine dioxide } \\
\end{array}$ \\
\hline High temperature destruction & $\begin{array}{l}\text { Electrical resistance heating } \\
\text { Microwave or radio-wave heating }\end{array}$ \\
\hline \multicolumn{2}{|l|}{ Photochemical degradation } \\
\hline \multicolumn{2}{|l|}{ Corona discharge } \\
\hline \multicolumn{2}{|l|}{ Neutralization } \\
\hline \multicolumn{2}{|l|}{ In Situ Immobilization Processes } \\
\hline \multicolumn{2}{|l|}{ Cryogenic barriers } \\
\hline \multicolumn{2}{|l|}{ Grouting } \\
\hline \multicolumn{2}{|l|}{ Vitrification } \\
\hline \multicolumn{2}{|l|}{ Precipitation } \\
\hline Microencapsulation & \\
\hline
\end{tabular}


sufficient moisture is present, the addition of a carrier phase is not required for electrokinetic separation.

Supercritical fluids (e.g., water or $\mathrm{CO}_{2}$ ) can also be used to transfer contaminants from soil into a gaseous carrier for removal and above ground treatment. While in situ application of this process is complex (e.g., maintaining the pressures necessary to keep the fluids supercritical), its potential capability justifies consideration.

In situ physical/chemical processes are being developed that transfer contaminants to the solid phase. In situ contaminant-transfer processes with a solid carrier phase are designed with the expectation that the solid phase will at some point be retrieved for further treatment. This removal of the adsorbed, immobilized contaminant is what distinguishes these processes from in situ contaminant immobilization processes. Adsorbents applicable to in situ treatment include granular activated carbon, zeolites, ion exchange resins, and other specialty materials. These adsorbents can be placed in trenches for shallow contaminants or lowered in canisters or other specially designed containers for deeper contaminants.

\subsubsection{In Situ Contaminant-Destruction Processes}

In situ contaminant-destruction processes alter or destroy contaminants in place. These technologies are applied to compounds that can either be converted to innocuous species such as $\mathrm{CO}_{2}$ and water or can be degraded to species that are non-toxic or amenable to other in situ processes (e.g., bioremediation). Chemical oxidation-reduction processes comprise one facet of in situ contaminant-destruction processes. With these processes, reagents such as hydrogen peroxide, ozone, potassium permanganate, and chlorine dioxide are contacted with subsurface contaminants to achieve remediation. In many instances, destruction is achieved by free-radical oxidation with hydroxyl radicals. Delivery and distribution of chemical reagents are critical to the effectiveness of these processes.

Another mode of in situ contaminant-destruction processes is the high temperature destruction of contaminants. These processes are still in the conceptual stage and are envisioned to be capable of destroying a wide variety of contaminants in situ at high temperatures (greater than $600{ }^{\circ} \mathrm{C}$ ). Several methods have been suggested to reach these high temperatures, such as electrical-resistance and microwave heating. Other contaminant-destruction processes include corona discharge and chemical dechlorination.

\subsubsection{In Situ Contaminant-Immobilization Processes}

At sites where in situ contaminant-transfer or destruction processes are not feasible options, in situ immobilization processes may sometimes be employed. These stabilization and solidification technologies fall into several categories: cryogenics (e.g., ground freezing); grouting-solidification (e.g., mixing the contaminated medium with cement- or polymer-based materials); microencapsulation (e.g., dispersing encapsulating agents throughout the contaminated medium); and vitrification (e.g., transforming the contaminated medium into a glass-like solid). All immobilization technologies are aimed at isolating contaminants from contact with the environment and at providing 
greater physical control of contamination. Stabilization and solidification treatment can be performed as an emergency "quick fix" to halt or reduce the spread of undesirable substances until further remedial action can be taken or for the purpose of long-term burial storage of hazardous and/or radioactive materials.

Conceptual technologies for in situ precipitation of heavy metals and/or radionuclides from soil and groundwater are emerging. In these treatment methods, a precipitating agent (e.g., iron filings or lime) is contacted with the contaminated waste stream using injection wells, trench and fill interception barriers, or chemical barrier linings. The contaminants are bound to the structure of a newly formed phase. Determination of potential clogging of groundwater flow paths is vital to the application of this technology.

Chemical compatibility between the contaminant and the immobilization or stabilization matrix is an important consideration. This compatibility can greatly affect long-term leachability of contaminates fixed by these methods and the water permeability of the stabilized, solidified waste form.

\subsection{STAGE OF DEVELOPMENT AND COMMERCIALIZATION}

A summary of information reported on the stage of development and applicability of commercially available and emerging ISPCT technologies is given in Appendix A. The information used to derive the summary is largely drawn from existing literature (e.g., U.S. Environmental Protection Agency (EPA) Vendor Information System for Innovative Treatment Technologies (VISITT), June, 1992; Superfund Innovative Technology Program (SITE) Technology Profiles, Nov., 1992; Federal Remediation Technologies Roundtable, May, 1991; NATO/CCMS pilot studies, April, 1988). Innovative technologies are undergoing rapid change and improvement, making it difficult to trace current information on their developmental status and commercial availability. Nevertheless, the limited information revealed that ISPCT technologies comprise only a small portion of the currently developed remediation technologies. For example, only 20 technologies out of 156 listed on the VISITT database and 10 out of 70 from the Federal Remediation Technologies Roundtable were identified as ISPCT. Among the existing technologies, most entries are found in the separation/transfer processes, with volatilization dominating. These technologies often treat one type of contaminant (for example, volatilization is targeted on volatile and semivolatile organic compounds) and cannot handle mixed wastes except with reduced efficiency. Most of the technologies have been field-tested at a site; with a few, only bench-scale testing was finished. Based on the reported information, an assessment of the stage of development and commercialization was made as indicated in Tables 3.2, 3.3 and 3.4.

\subsection{OTHER NATIONAL R\&D PROGRAMS}

A variety of federal government agencies and national institutions sponsor R\&D in areas related to ISPCT technologies. To help identify gaps in ISPCT technologies that need to be pursued by the DOE ISR IP, information was sought from other potential sponsors. These included the following groups: (1) DOE; (2) EPA; (3) U.S. Department of Defense (DOD) (Air Force and Army); (4) Gas Research Institute (GRI); (5) Electric Power Research Institute (EPRI); and (6) National Science Foundation (NSF). The highlights of this review are presented in Table 3.5, while further explanation is provided in Appendix B. 
Table 3.2. Assessed stage of the development and applicability of in situ contaminanttransfer processes for remediation of DOE sites.

\begin{tabular}{|c|c|c|c|c|c|c|c|}
\hline \multicolumn{2}{|c|}{$\begin{array}{l}\text { In situ contaminant-transfer } \\
\text { processes }\end{array}$} & \multirow{2}{*}{$\begin{array}{l}\text { Radio- } \\
\text { nuclides }\end{array}$} & \multirow{2}{*}{ Metals } & \multirow{2}{*}{$\begin{array}{l}\text { Chlorinated } \\
\text { hydrocarbons }\end{array}$} & $\begin{array}{l}\text { Fuel } \\
\text { hydro- } \\
\text { carbons }\end{array}$ & \multirow{2}{*}{ Nitrates } & \multirow{2}{*}{$\frac{\mathrm{PCBs}}{-}$} \\
\hline Volatil- & Air sparging & & & & $\pm F$ & & \\
\hline & Vacuum extraction & - & - & $+\mathrm{F}$ & $\pm F$ & - & - \\
\hline & $\begin{array}{l}\text { Hot air or steam } \\
\text { extraction }\end{array}$ & - & - & $+F$ & $\pm P$ & - & - \\
\hline & $\begin{array}{l}\text { Thermally } \\
\text { enhanced } \\
\text { a. microwave } \\
\text { b. radio frequency }\end{array}$ & - & - & $+\mathrm{P}$ & $\pm \mathrm{C}$ & - & - \\
\hline \multirow[t]{3}{*}{ Adsorption } & $\begin{array}{l}\text { granular activated } \\
\text { carbon }\end{array}$ & $+B$ & $+\mathrm{B}$ & $+B$ & $\pm C$ & - & $+B$ \\
\hline & Zeolites & $+\mathrm{B}$ & $+\mathrm{B}$ & NDF & NDF & $\mathrm{NDF}$ & NDF \\
\hline & Other materials & NDF & $+B$ & NDF & NDF & NDF & NDF \\
\hline \multirow[t]{3}{*}{ Leaching } & Surfactants & - & - & $+\mathrm{B}$ & $+\mathrm{B}$ & - & $\mathrm{NDF}$ \\
\hline & Chelating agents & $+\mathrm{B}$ & $+\mathrm{P}$ & - & - & $\mathrm{NDF}$ & NDF \\
\hline & Acids or bases & $+\mathrm{B}$ & $+\mathrm{B}$ & - & - & $\mathrm{NDF}$ & - \\
\hline \multirow{3}{*}{$\begin{array}{l}\text { Combinations } \\
\text { of transfer } \\
\text { processes }\end{array}$} & $\begin{array}{l}\text { Reactive } \\
\text { membranes }\end{array}$ & $\pm C$ & $+B$ & - & - & $\mathrm{NDF}$ & NDF \\
\hline & Saponification & - & - & $+\mathrm{P}$ & $+\mathrm{P}$ & - & $+\mathrm{B}$ \\
\hline & $\begin{array}{l}\text { Washing and } \\
\text { adsorption }\end{array}$ & - & $+F$ & $+P$ & $+\mathrm{P}$ & NDF & NDF \\
\hline Ion exchange & Zeolites & $+\mathrm{B}$ & $+B$ & - & $\mathrm{NDF}$ & $\mathrm{NDF}$ & NDF \\
\hline \multicolumn{2}{|l|}{ Electrokinetics } & $+\mathrm{P}$ & $+P$ & $+\mathrm{P}$ & NDF & NDF & NDF \\
\hline
\end{tabular}

Radionuclides: tritium, uranium, strontium, plutonium, cesium, cobalt, technetium

Metals: lead, chromium, arsenic, zinc, copper, mercury, cadmium, nickel

Chlorinated hydrocarbons: trichloroethylene, 1,1,1-trichloroethane, 1,2-dichloroethylene, chloroform, dichloromethane

Fuel hydrocarbons: benzene, toluene, xylenes, ethylbenzene

F: Field-scale demonstrations completed

P: Pilot-scale demonstrations completed

B: Bench-scale experiments completed

C: Conceptual development stage technology
+: technology applicable

$-:$ technology not applicable

\pm : technology has some applicability

NDF: no data found to evaluate application 
Table 3.3. Assessed stage of the development and applicability of in situ contaminantdestruction processes for remediation of DOE sites.

\begin{tabular}{|c|c|c|c|c|c|c|c|}
\hline \multicolumn{2}{|c|}{$\begin{array}{l}\text { In situ contaminant- } \\
\text { destruction processes }\end{array}$} & \multirow{2}{*}{$\begin{array}{l}\text { Radio- } \\
\text { nuclides }\end{array}$} & \multirow{2}{*}{ Metals } & \multirow{2}{*}{$\begin{array}{l}\begin{array}{l}\text { Chlorinated } \\
\text { hydrocarbons }\end{array} \\
+\mathrm{P}\end{array}$} & \multirow{2}{*}{$\begin{array}{l}\begin{array}{l}\text { Fuel } \\
\text { hydro- } \\
\text { carbons }\end{array} \\
+\mathrm{B}\end{array}$} & \multirow{2}{*}{$\frac{\text { Nitrates }}{\text { NDF }}$} & \multirow{2}{*}{$\frac{\text { PCBs }}{\text { NDF }}$} \\
\hline Chemical & Hydrogen peroxide & & & & & & \\
\hline & Ozone & - & $\pm C$ & $+\mathrm{B}$ & $+\mathrm{B}$ & $\mathrm{NDF}$ & $\mathrm{NDF}$ \\
\hline & $\begin{array}{l}\text { Potassium } \\
\text { permanganate }\end{array}$ & - & - & $+B$ & $+\mathrm{B}$ & NDF & $\mathrm{NDF}$ \\
\hline & Solvated electrons & - & - & $\mathrm{NDF}$ & $\mathrm{NDF}$ & $\mathrm{NDF}$ & $\pm C$ \\
\hline & Chlorine dioxide & - & - & $\mathrm{NDF}$ & $\mathrm{NDF}$ & $\mathrm{NDF}$ & NDF \\
\hline \multirow{2}{*}{$\begin{array}{l}\text { High } \\
\text { temperature } \\
\text { destruction }\end{array}$} & $\begin{array}{l}\text { Electrical } \\
\text { resistance heating }\end{array}$ & - & - & $\mathrm{NDF}$ & $\mathrm{NDF}$ & NDF & $+B$ \\
\hline & $\begin{array}{l}\text { Microwave or } \\
\text { radio-wave heating }\end{array}$ & - & - & $\pm B$ & $\mathrm{NDF}$ & $\mathrm{NDF}$ & $\pm C$ \\
\hline \multicolumn{2}{|c|}{ Chemical degradation } & - & - & $\mathrm{NDF}$ & $\mathrm{NDF}$ & $\mathrm{NDF}$ & $\mathrm{NDF}$ \\
\hline \multicolumn{2}{|c|}{ Corona discharge } & - & - & $\pm \mathrm{B}$ & $\mathrm{NDF}$ & NDF & $\mathrm{NDF}$ \\
\hline \multicolumn{2}{|c|}{ Neutralization } & - & - & $\mathrm{NDF}$ & $\mathrm{NDF}$ & $\mathrm{NDF}$ & NDF \\
\hline \multicolumn{2}{|c|}{ Dechlorination } & - & - & $+B$ & $\mathrm{NDF}$ & $\mathrm{NDF}$ & $+B$ \\
\hline
\end{tabular}

Radionuclides: tritium, uranium, strontium, plutonium, cesium, cobalt, technetium

Metals: lead, chromium, arsenic, zinc, copper, mercury, cadmium, nickel

Chlorinated hydrocarbons: trichloroethylene, 1,1,1-trichloroethane, 1,2-dichloroethylene, chloroform, dichloromethane

Fuel hydrocarbons: benzene, toluene, xylenes, ethylbenzene

F: Field-scale demonstrations completed

$+:$ technology applicable

P: Pilot-scale demonstrations completed

-: technology not applicable

B: Bench-scale experiments completed

\pm : technology has some applicability

C: Conceptual development stage technology

NDF: no data found to evaluate application 
Table 3.4. Assessed stage of the development and applicability of in situ contaminant immobilization processes for remediation of DOE sites.

\begin{tabular}{|c|c|c|c|c|c|c|}
\hline $\begin{array}{l}\text { In situ contaminant- } \\
\text { immobilization processes }\end{array}$ & $\begin{array}{l}\text { Radio- } \\
\text { nuclides }\end{array}$ & Metals & $\begin{array}{l}\text { Chlorinated } \\
\text { hydrocarbons }\end{array}$ & $\begin{array}{l}\text { Fuel } \\
\text { hydro- } \\
\text { carbons }\end{array}$ & Nitrates & PCBs \\
\hline Cryogenics & $+\mathrm{C}$ & $+\mathrm{C}$ & - & - & $+\mathrm{C}$ & $\pm C$ \\
\hline Grouting & $+P$ & $+F$ & \pm & \pm & - & + \\
\hline Solidification & + & $+F$ & $+P$ & $+F$ & $+F$ & + \\
\hline Microencapsulation & + & + & \pm & \pm & \pm & $+F$ \\
\hline Vitrification & $+F$ & $+F$ & $+F$ & $+F$ & NDF & + \\
\hline Precipitation & $+\mathrm{C}$ & $+B$ & - & - & - & - \\
\hline
\end{tabular}

Radionuclides: tritium, uranium, strontium, plutonium, cesium, cobalt, technetium

Metals: lead, chromium, arsenic, zinc, copper, mercury, cadmium, nickel

Chlorinated hydrocarbons: trichloroethylene, 1,1,1-trichloroethane, 1,2-dichloroethylene, chloroform, dichloromethane

Fuel hydrocarbons: benzene, toluene, xylenes, ethylbenzene

F: Field-scale demonstrations completed

P: Pilot-scale demonstrations completed

B: Bench-scale experiments completed

C: Conceptual development stage technology
$+:$ technology applicable

-: technology not applicable

\pm : technology has some applicability

NDF: no data found to evaluate application 


\section{Table 3.5 Highlights of national $\mathrm{R} \& \mathrm{D}$ programs with activities relevant to ISPCT technologies.}

\begin{tabular}{|c|c|c|c|c|}
\hline $\begin{array}{l}\text { Sponsoring } \\
\text { agency }\end{array}$ & $\begin{array}{l}\text { Agency } \\
\text { unit }\end{array}$ & $\begin{array}{l}\text { Program } \\
\text { goals } \\
\text { relevant to } \\
\text { ISPCT }\end{array}$ & $\begin{array}{l}\text { Relevant } \\
\text { ISPCT } \\
\text { projects } \\
\text { ongoing }\end{array}$ & Principal ISPCT areas of emphasis ${ }^{a}$ \\
\hline \multirow[t]{3}{*}{$\mathrm{DOE}$} & OTD & Yes & Yes & $\begin{array}{l}\text { Removal of VOCs, development of horizontal well } \\
\text { technologies, destruction of VOCs, thermal } \\
\text { enhancement of vapor extraction, supercritical } \\
\text { water oxidation, stabilization of metals and } \\
\text { radioactive nuclides, and removal of metals and } \\
\text { radioactive nuclides. }\end{array}$ \\
\hline & OER & Yes & Yes & $\begin{array}{l}\text { Basic research on biosorption, scavenging colloids, } \\
\text { supercritical fluid processes, complexation of } \\
\text { radionuclides with organic and inorganic } \\
\text { compouncis, heating, and oxidation. }\end{array}$ \\
\hline & Site ER & Yes & Yes & Variable depending on site-specific needs. \\
\hline EPA & $\begin{array}{l}\text { Office of } \\
\text { Exploratory } \\
\text { Research }\end{array}$ & Yes & Yes & $\begin{array}{l}\text { Solubilization of PAH using surfactants, prevention } \\
\text { of bacteria or precipitate well-aquifer interface } \\
\text { plugging, destruction of chlorinated hydrocarbons, } \\
\text { removal of heavy metals, transport of heavy metals, } \\
\text { oxidation of organics using supercritical oxidation. } \\
\text { A majority of the funded projects investigated the } \\
\text { removal of heavy metals from the environment. }\end{array}$ \\
\hline
\end{tabular}

\begin{tabular}{|c|c|c|}
\hline $\begin{array}{l}\text { SITE } \\
\text { Demo } \\
\text { Program }\end{array}$ & Yes & $\begin{array}{l}\text { Immobilization of metals using reduction, enhanced } \\
\text { volatilization using physical processes, fracturing for } \\
\text { improving subsurface mass transfer, radio frequency } \\
\text { heating, destruction of VOCs, and the CROW'TM } \\
\text { process. }\end{array}$ \\
\hline
\end{tabular}

\begin{tabular}{|c|c|c|c|}
\hline $\begin{array}{l}\text { SITE } \\
\text { Emerging } \\
\text { Technology } \\
\text { Program }\end{array}$ & Yes & Yes & $\begin{array}{l}\text { Destruction of organic contaminants using oxidation } \\
\text { and catalytic processes, fracturing, CROW } \\
\text { process, and the use of electric or acoustic fields for } \\
\text { removal of heavy metals. }\end{array}$ \\
\hline
\end{tabular}

\begin{tabular}{|c|c|c|c|c|}
\hline \multirow[t]{2}{*}{ DOD } & Air Force & Yes & Yes & $\begin{array}{l}\text { Measurement of subsurface mass transfer, soil-vapor } \\
\text { extraction (including ambient and soil heating } \\
\text { techniques), immobilization of heavy metals, and } \\
\text { contaminant destruction using catalytic and } \\
\text { ultraviolet light oxidation methods. }\end{array}$ \\
\hline & Army & Yes & Yes & $\begin{array}{l}\text { Stabilization of metals in sediments and soils, } \\
\text { treatment and removal of organic compounds from } \\
\text { sediments, investigation of leaching processes, } \\
\text { modeling of seepage and groundwater flow, } \\
\text { evaluation and development thermal stripping } \\
\text { techniques for remediation of hydrocarbon- and } \\
\text { solvent-contaminated soils. }\end{array}$ \\
\hline
\end{tabular}

a Additional information regarding the programs listed can be found in Appendix B. 
Table 3.5 Highlights of national R\&D programs with activities relevant to ISPCT technologies (continued).

\begin{tabular}{lllll}
\hline $\begin{array}{l}\text { Sponsoring } \\
\text { agency }\end{array}$ & $\begin{array}{l}\text { Agency } \\
\text { unit }\end{array}$ & $\begin{array}{l}\text { Program } \\
\text { goals } \\
\text { relevant to } \\
\text { ISPCT }\end{array}$ & $\begin{array}{l}\text { Relevant } \\
\text { ISPCT } \\
\text { projects } \\
\text { ongoing }\end{array}$ & Principal ISPCT areas of emphasis $a$ \\
\hline EPRI & Yes & Yes & $\begin{array}{l}\text { Remediation techniques for PAH and fuel } \\
\text { contamination at coal-gas sites and LUST sites. }\end{array}$ \\
\hline GRI & Yes & Yes & $\begin{array}{l}\text { Physical/chemical treatment interests include } \\
\text { CROWTM process, UV/oxidation for destruction of } \\
\text { metal cyanide complexes, Fenton's reagent for } \\
\text { degradation of hydrocarbons. }\end{array}$ \\
\hline NSF & No & No & $\begin{array}{l}\text { Some relevant basic and applied research but not } \\
\text { focused on environmental restoration needs. }\end{array}$ \\
\hline SBIR & Yes & No & Individual agency programs include ISPCT R\&D. \\
\hline$a$ Additional information regarding the programs listed can be found in Appendix B.
\end{tabular}

$a$ Additional information regarding the programs listed can be found in Appendix B. 



\section{RESEARCH AND DEVELOPMENT FOR ISPCT TECHNOLOGIES}

\subsection{INTRODUCTION}

The R\&D program for the ISPCT subarea of the ISR IP must be developed based on an assessment of the available information regarding DOE-complex needs, technology development status, and other R\&D programs. Within the ISR IP, allocation of scarce resources must be made for development of technologies that have potential for satisfying pressing DOE needs and that are not being vigorously pursued by others. The subarea program is focused on research, development, and testing to provide new technologies and increased knowledge of operation and performance of emerging technologies (Fig. 4.1). A proposed framework for the R\&D program for ISPCT technologies is provided in this section; details within the framework will evolve and grow with subsequent versions of this report and as it is integrated with the other three ISR focus areas.

\subsection{TECHNICAL GAPS}

As discussed in the prior sections, there are gaps in the resolution of pressing DOEcomplex needs and the stage of development of potential ISPCT technologies (Tables 3.2, 3.3 and 3.4). These gaps encompass both contamination scenarios (i.e., contaminants and physical conditions) coupled with uncertain operation and performance information for many emerging technologies under the diversity of conditions for which they may be feasible, effective, and cost-efficient. The gaps consist of inadequate information, particularly at the intermediate- and field-scale, in the following areas: (1) performance potential, (2) implementation constraints, (3) limitations to applicability, and (4) verification of performance. More specifically, technical gaps within many ISPCT technologies encompass one or more of the following areas:

o Definition of reaction kinetics and thermodynamics and effects of sitespecific geochemical conditions,

o $\quad$ Effects of mass transfer on dispersal of treatment agents and recovery of contaminants and byproducts throughout a subsurface region of interest,

o Effects of highly heterogeneous subsurface conditions on treatment efficiency within a region of interest,

o Effects of coupling processes to treat mixtures of contaminants, and

o Techniques for field process monitoring and control to ascertain if a desired treatment efficiency has been achieved.

Current and near-term gaps in ISPCT technologies for application to DOE needs are highlighted in Table 4.1. It is emphasized that this table is not exhaustive, but is rather illustrative of the types of gaps for which R\&D opportunities exist. 


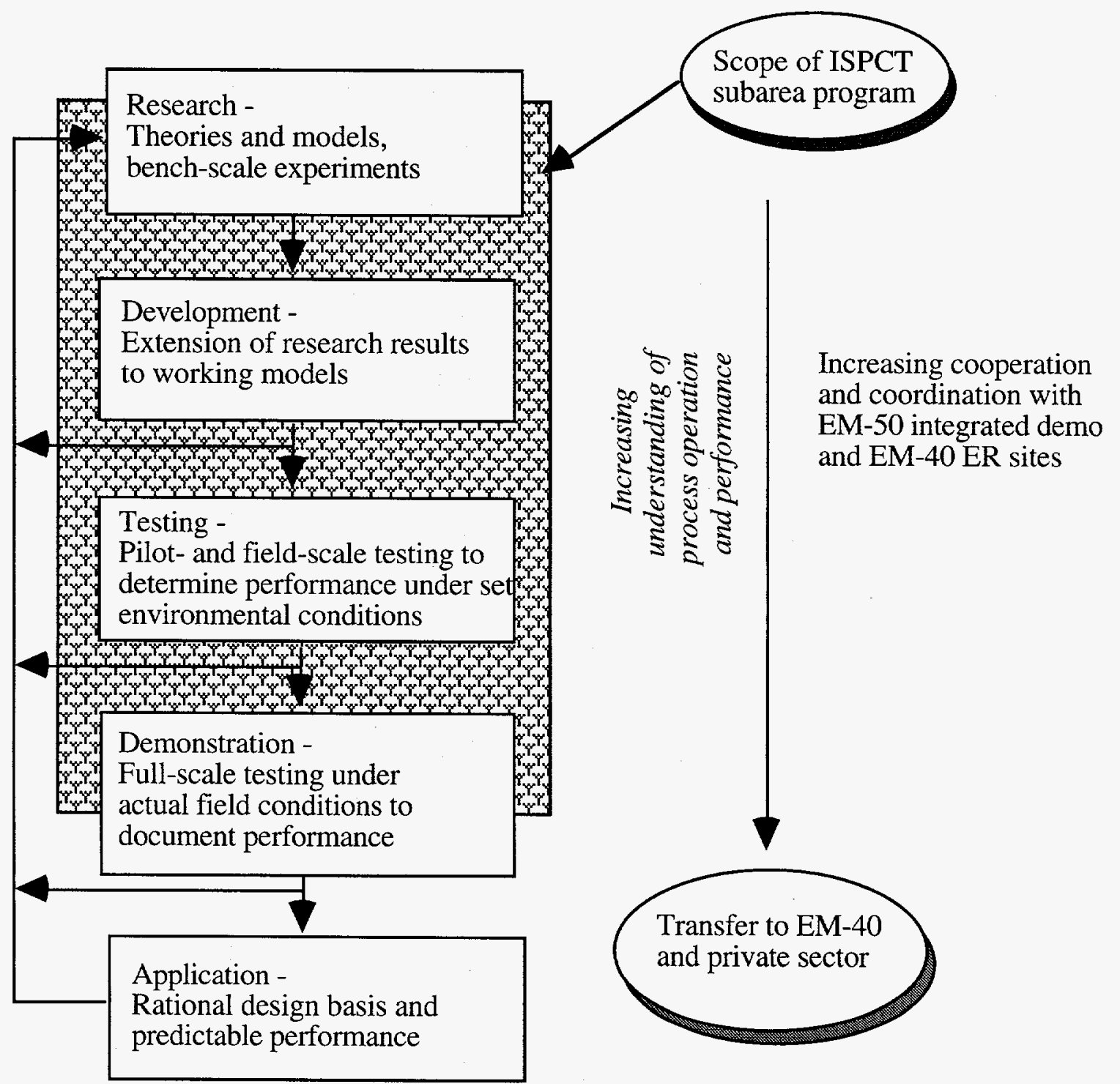

Fig. 4.1. Technology development stages and scope of ISPCT subarea. 
Table 4.1. Current and near-term gaps in technology development for ISPCT technologies.

\begin{tabular}{|c|c|c|}
\hline Process area & $\begin{array}{l}\text { Example } \\
\text { technology }\end{array}$ & Illustrative technical gaps ${ }^{a}$ \\
\hline \multicolumn{3}{|l|}{ Transfer } \\
\hline Volatilization & Vapor extraction & $\begin{array}{l}\text { Mass-transfer efficiency in heterogeneous and } \\
\text { low-permeability media; effects of energy } \\
\text { enhancements; applicability to DNAPL } \\
\text { treatment; co-processing with biodegradation }\end{array}$ \\
\hline Adsorption & $\begin{array}{l}\text { Zeolites and } \\
\text { reactive sorbents }\end{array}$ & $\begin{array}{l}\text { Sorbent selectivity and interferences; flow } \\
\text { and distribution control of contaminants } \\
\text { across the media; mass transfer across } \\
\text { media/sorbent interfaces; fouling of sorbents } \\
\text { associated with subsurface system } \\
\text { geochemistry }\end{array}$ \\
\hline Leaching & Soil flushing & $\begin{array}{l}\text { Surfactants, chelating agents, and other agents } \\
\text { to mobilize bound and particulate material; } \\
\text { delivery of reagents to the soil }\end{array}$ \\
\hline Extraction & Supercritical fluids & $\begin{array}{l}\text { Mass-transfer efficiency for contaminant } \\
\text { removal by supercritical fluids }\end{array}$ \\
\hline \multicolumn{3}{|l|}{ Destruction } \\
\hline \multirow[t]{2}{*}{$\begin{array}{l}\text { Chemical } \\
\text { oxidation- } \\
\text { reduction }\end{array}$} & Oxidation & $\begin{array}{l}\text { Site-specific geochemical effects on reaction } \\
\text { kinetics and thermodynamics of liquid-phase } \\
\text { and gas-phase oxidants; in situ catalysis and } \\
\text { generation of free-radical oxidants; technical } \\
\text { viability of gas-phase oxidation processes }\end{array}$ \\
\hline & Reduction & $\begin{array}{l}\text { Reaction kinetics and thermodynamics of } \\
\text { transition-metal catalysts for dechlorination of } \\
\text { halogenated organic compounds and } \\
\text { precipitation of metals and radionuclides }\end{array}$ \\
\hline High-energy & Pyrolysis & $\begin{array}{l}\text { Energy consumption as affected by site- } \\
\text { specific matrix properties; nature and extent } \\
\text { of incomplete combustion byproducts }\end{array}$ \\
\hline
\end{tabular}

\begin{tabular}{cl}
\hline Immobilization & \\
\hline Precipitation & $\begin{array}{l}\text { Geochemistry of injected agents and } \\
\text { homogeneity of agent/media mixtures }\end{array}$
\end{tabular}

a The information shown is for illustrative purposes only. The order of presentation does not represent the priority of the technical gap. Although some information is available on these technical gaps, additional specific information is necessary. This table is undergoing further development and refinement and will be updated periodically. 


\subsection{R\&D OPPORTUNITIES}

R\&D opportunities exist to expedite implementation of ISPCT technologies that have great potential to satisfy DOE-complex needs. This R\&D should emphasize the following:

o Treatment at sources of contamination and groundwater plume boundaries,

o Treatment within complex and heterogeneous hydrogeologic regimes,

$0 \quad$ Treatment of mixtures of contaminants including radioactive substances and hazardous VOCs,

o Treatment of dense, non-aqueous-phase liquids,

o Treatment of light, non-aqueous-phase liquids,

o Experimentation at the pilot- and field-scale level,

- Experimentation involving comparative studies of competing processes, and

o Development of process monitoring and control and performance verification technologies.

Within the DOE ISR program, several R\&D projects were initiated during FY 1993 and 1994 that are focused on ISPCT technologies (Table 4.2). These projects are focused on (1) electrokinetics, (2) chemical treatment barriers, and (3) chemical treatment.

In addition to further R\&D to support development of emerging technologies, there is also a need to develop new concepts heretofore unknown. This innovative R\&D will be supported as part of this subarea program.

Priorities for R\&D funding within the ISR IP for ISPCT technologies have been outlined in Table 4.3. These priorities are intended to illustrate currently perceived R\&D needs in the ISPCT subarea for which proposals will be solicited and given consideration. However, proposals for other technical work associated with the subarea will also be given consideration.

\subsection{PROGRAM FUNDING AND MILESTONES}

Individual R\&D projects are anticipated to last one to two years, with funding from the ISPCT program. During this period, experimentation can occur at the bench-, pilot-, or field-scale levels. By the end of two years, it is assumed that funded efforts will either be terminated, transferred to another funding source (e.g., integrated demonstration or site EM), or co-funded. Funding levels per project are anticipated to range from $\$ 250$ to $\$ 1000 \mathrm{~K}$ per year during the initial two years. The total investment per project will not exceed more than 3 years or $\$ 2000 \mathrm{~K}$ except under unusual circumstances. 
Table 4.2. Currently funded projects within the DOE ISR program that focus on ISPCT technologies.

\begin{tabular}{|c|c|c|c|c|}
\hline Title & $\begin{array}{l}\text { Project } \\
\text { TTP } \\
\text { number }\end{array}$ & $\begin{array}{l}\text { Principle } \\
\text { Investigator }\end{array}$ & $\begin{array}{l}\text { Approx. } \\
\text { funding: } \\
\text { FY, } \$\end{array}$ & Comments \\
\hline \multicolumn{5}{|l|}{ Electrokinetics } \\
\hline $\begin{array}{l}\text { Electrokinetic remediation } \\
\text { of heavy-metal- } \\
\text { contaminated unsaturated } \\
\text { soil }\end{array}$ & AL231009 & $\begin{array}{l}\text { E. Lindgren, } \\
\text { SNL }\end{array}$ & $\begin{array}{l}\text { FY93, 400K } \\
\text { FY94, 420K } \\
\text { FY95, 100K }\end{array}$ & $\begin{array}{l}\text { Removal of chromate from } \\
\text { unsaturated soil in support of } \\
\text { the MWLID. }\end{array}$ \\
\hline $\begin{array}{l}\text { Electrokinetic removal of } \\
\text { heavy-metal and mixed } \\
\text { waste from partially and } \\
\text { fully saturated soils }\end{array}$ & HQ031004 & $\begin{array}{l}\text { R. Probstein, } \\
\text { MIT }\end{array}$ & $\begin{array}{l}\text { FY93, 250K } \\
\text { FY94, 250K } \\
\text { FY95, 100K }\end{array}$ & $\begin{array}{l}\text { Development of a } \\
\text { fundamental understanding } \\
\text { and model of electrokinetics } \\
\text { in non-arid regions. }\end{array}$ \\
\hline $\begin{array}{l}\text { Field demonstration of } \\
\text { electrokinetic migration } \\
\text { technology at the old TNX } \\
\text { (disposal) basin }\end{array}$ & SR131003 & $\begin{array}{l}\text { J. Bibler, } \\
\text { WSRC }\end{array}$ & $\begin{array}{l}\text { FY93, 500K } \\
\text { FY94, 720K }\end{array}$ & $\begin{array}{l}\text { Development of technology to } \\
\text { remove mercury contaminants } \\
\text { from non-arid unsaturated } \\
\text { soil. }\end{array}$ \\
\hline $\begin{array}{l}\text { Field demonstration of } \\
\text { electrokinetic migration } \\
\text { technology at the K-25 site }\end{array}$ & OR221102 & $\begin{array}{l}\text { R. Swatzell, } \\
\text { HAZWRAP }\end{array}$ & $\begin{array}{l}\text { FY93, } 550 \mathrm{~K} \\
\text { FY94, 1815K }\end{array}$ & $\begin{array}{l}\text { Development of technology to } \\
\text { remove uranium contaminants } \\
\text { from unsaturated soil. }\end{array}$ \\
\hline \multicolumn{5}{|l|}{ Chemical Barriers } \\
\hline $\begin{array}{l}\text { Chemical-barriers feasibility } \\
\text { and field demonstration }\end{array}$ & AL931002 & $\begin{array}{l}\text { S. Morrison, } \\
\text { RUST } \\
\text { Geotech }\end{array}$ & $\begin{array}{l}\text { FY93, 500K } \\
\text { FY94, 840K }\end{array}$ & $\begin{array}{l}\text { Use of a ferric oxyhydroxide } \\
\text { colloidal suspension for in } \\
\text { situ control of radionuclide } \\
\text { and metal contamination in } \\
\text { groundwater. }\end{array}$ \\
\hline $\begin{array}{l}\text { Chemically enhanced } \\
\text { barriers to minimize } \\
\text { contaminant migration in } \\
\text { sediments }\end{array}$ & RL331002 & $\begin{array}{l}\text { K. Cantrell, } \\
\text { Battelle }\end{array}$ & $\begin{array}{l}\text { FY93, 570K } \\
\text { FY94, 500K } \\
\text { FY95, } 875 \mathrm{~K}\end{array}$ & $\begin{array}{l}\text { Development and evaluation } \\
\text { of hydraulic and diffusion } \\
\text { barriers and permeable } \\
\text { barriers. }\end{array}$ \\
\hline In situ magnetic separation & $\mathrm{CH} 231005$ & $\begin{array}{l}\text { D. Johnson, } \\
\text { ANL }\end{array}$ & $\begin{array}{l}\text { FY93, 1400K } \\
\text { FY94, 3385K }\end{array}$ & $\begin{array}{l}\text { Development and testing of } \\
\text { an in situ magnetic separation } \\
\text { process for removal of heavy } \\
\text { metals from groundwater. }\end{array}$ \\
\hline
\end{tabular}


Table 4.2. Currently funded projects within the DOE ISR program that focus on ISPCT technologies (continued).

\begin{tabular}{|c|c|c|c|c|}
\hline Title & $\begin{array}{l}\text { Project } \\
\text { TTP } \\
\text { number }\end{array}$ & $\begin{array}{l}\text { Principal } \\
\text { investigator }\end{array}$ & $\begin{array}{l}\text { Approx. } \\
\text { funding: } \\
\text { FY, } \$\end{array}$ & Comments \\
\hline \multicolumn{5}{|c|}{ Physical/Chemical Treatment } \\
\hline $\begin{array}{l}\text { NAPL remediation using } \\
\text { foam }\end{array}$ & $\mathrm{CH} 241003$ & $\begin{array}{l}\text { R. Peters } \\
\text { ANL }\end{array}$ & FY94, 250K & $\begin{array}{l}\text { Use of foams to release and } \\
\text { mobilize NAPL contaminants } \\
\text { in the subsurface coupled with } \\
\text { bioremediation. }\end{array}$ \\
\hline In situ redox manipulation & RL331005 & $\begin{array}{l}\text { J. Fruchter, } \\
\text { Battelle }\end{array}$ & $\begin{array}{l}\text { FY93, } 425 \mathrm{~K} \\
\text { FY94, 730K } \\
\text { FY95, 500K }\end{array}$ & $\begin{array}{l}\text { Development and testing of } \\
\text { immobilization of inorganic } \\
\text { compounds and destruction of } \\
\text { organic compounds by } \\
\text { altering system chemistry. }\end{array}$ \\
\hline $\begin{array}{l}\text { In situ chemical treatment: } \\
\text { evaluation of in situ } \\
\text { chemical treatment approach } \\
\text { for remediation of soil and } \\
\text { groundwater }\end{array}$ & RL431001 & $\begin{array}{l}\text { E. Thorton, } \\
\text { WHC }\end{array}$ & $\begin{array}{l}\text { FY93, 170K } \\
\text { FY94, 300K } \\
\text { FY95, 170K }\end{array}$ & $\begin{array}{l}\text { Development of an in situ } \\
\text { treatment approach involving } \\
\text { injection of reactive gases. }\end{array}$ \\
\hline $\begin{array}{l}\text { In situ corona for in situ } \\
\text { treatment of non-volatile } \\
\text { organic contaminants }\end{array}$ & RL331006 & $\begin{array}{l}\text { R. Moss, } \\
\text { Battelle }\end{array}$ & $\begin{array}{l}\text { FY93, 250K } \\
\text { FY94, 107K } \\
\text { FY95, 250K }\end{array}$ & $\begin{array}{l}\text { Development of a technique } \\
\text { for decomposing nonvolatile } \\
\text { and bound organic } \\
\text { compounds using gas-phase } \\
\text { oxidants generated in situ by } \\
\text { electrical corona. }\end{array}$ \\
\hline $\begin{array}{l}\text { In situ chemical oxidation of } \\
\text { soils }\end{array}$ & OR141001 & $\begin{array}{l}\text { D. Gates } \\
\text { ORNL }\end{array}$ & FY94, 300K & $\begin{array}{l}\text { Study to determine the } \\
\text { conditions when chemical } \\
\text { oxidation can be effectively } \\
\text { utilized as an in situ treatment } \\
\text { process for soils contaminated } \\
\text { with hydrocarbons and/or } \\
\text { metals. }\end{array}$ \\
\hline $\begin{array}{l}\text { Remediation of DNAPL in } \\
\text { low permeability media }\end{array}$ & OR131007 & $\begin{array}{l}\text { R. Siegrist } \\
\text { ORNL }\end{array}$ & FY94, 536K & $\begin{array}{l}\text { Testing and evaluation of in } \\
\text { situ remediation technologies } \\
\text { for both source control and } \\
\text { mass removal of DNAPLs. }\end{array}$ \\
\hline $\begin{array}{l}\text { Mixed contamination in } \\
\text { groundwater }\end{array}$ & OR141002 & $\begin{array}{l}\text { R. Siegrist, } \\
\text { N. Korte } \\
\text { ORNL }\end{array}$ & FY94, 310K & $\begin{array}{l}\text { Evaluation of horizontal wells } \\
\text { for inducing groundwater } \\
\text { recirculation and development } \\
\text { of below-ground treatment } \\
\text { modules for VOC and } \\
\text { radionuclide removal. }\end{array}$ \\
\hline
\end{tabular}


Table 4.3. R\&D opportunities for ISPCT technologies.

\begin{tabular}{|c|c|c|}
\hline Technology area & $\begin{array}{l}\text { Target contaminants } \\
\text { (media) }\end{array}$ & Technical gap ${ }^{a}$ \\
\hline \multicolumn{3}{|l|}{ Near-term } \\
\hline Volatilization & $\begin{array}{l}\text { VOCs, DNAPLs } \\
\text { (soil, } \\
\text { low permeability media) }\end{array}$ & $\begin{array}{l}\text { Heating and directed-energy methods to enhance } \\
\text { mass transfer of volatile contaminants }\end{array}$ \\
\hline \multirow[t]{3}{*}{$\begin{array}{l}\text { Chemical } \\
\text { oxidation-reduction }\end{array}$} & $\begin{array}{l}\text { TCE, PCE, CT ... } \\
\text { Tc-99 ... } \\
\text { (groundwater) }\end{array}$ & $\begin{array}{l}\text { Elemental metal catalysts for reductive } \\
\text { dechlorination and precipitation of chlorinated } \\
\text { organic compounds, metals, and radionuclides }\end{array}$ \\
\hline & $\begin{array}{l}\text { VOCs, } \\
\text { Organic compounds } \\
\text { Metals } \\
\text { (soil, groundwater) }\end{array}$ & $\begin{array}{l}\text { Liquid-phase, stable oxidation-reduction agents } \\
\text { to destroy organic compounds and mobilize } \\
\text { metals for recovery; or immobilize metals }\end{array}$ \\
\hline & $\begin{array}{l}\text { VOCs, } \\
\text { Heavy metals } \\
\text { (soil) }\end{array}$ & $\begin{array}{l}\text { Gas-phase oxidation-reduction to enhance } \\
\text { dispersal of agents throughout contaminated soil } \\
\text { regions within source areas }\end{array}$ \\
\hline Adsorption & $\begin{array}{l}\text { Heavy metals, } \\
\text { Radionuclides } \\
\text { (groundwater) }\end{array}$ & $\begin{array}{l}\text { Zeolite and sorbent media with increased } \\
\text { selectivity and efficiency and reduced fouling } \\
\text { potential }\end{array}$ \\
\hline Leaching & $\begin{array}{l}\text { TCE and PCE DNAPLs } \\
\text { (soil and groundwater) }\end{array}$ & $\begin{array}{l}\text { Surfactants for enhancing mobilization and } \\
\text { recovery of TCE and PCE DNAPLs }\end{array}$ \\
\hline Electrokinetics & $\begin{array}{l}\text { Heavy metals, } \\
\text { Radionuclides } \\
\text { (soil) }\end{array}$ & $\begin{array}{l}\text { Chelating agents and other agents to enhance } \\
\text { electrokinetic-enabled migration and removal of } \\
\text { bound and particulate materials in different } \\
\text { geochemical settings }\end{array}$ \\
\hline \multicolumn{3}{|l|}{ Longer-term } \\
\hline Filtration & $\begin{array}{l}\mathrm{U}, \mathrm{Tc}, \\
\text { (groundwater) }\end{array}$ & Reactive membranes \\
\hline Extraction & $\begin{array}{l}\text { Non-volatile organic } \\
\text { compounds } \\
\text { (soil) }\end{array}$ & $\begin{array}{l}\text { In situ supercritical fluid extraction processes to } \\
\text { enable removal of non-volatile organic } \\
\text { compounds from subsurface regions }\end{array}$ \\
\hline Combinations & $\begin{array}{l}\mathrm{U}, \mathrm{Tc}, \mathrm{Cr}, \mathrm{VOCs} \\
\text { (groundwater) }\end{array}$ & $\begin{array}{l}\text { Reactive colloids to migrate preferentially } \\
\text { through contaminated regions and to effect } \\
\text { treatment }\end{array}$ \\
\hline
\end{tabular}

$a \quad$ The information shown was derived from DOE-complex needs and technology development status; at this time, it is for illustrative purposes only. The order of presentation does not represent the priority of the technical gap. This table is undergoing further development and refinement and will be updated periodically. 
The estimated funding requirements associated with the ISPCT subarea are anticipated to be:
FY 1993: \$2500K
FY 1994: \$3000K
FY 1995: \$4000K
FY 1996: \$5000K
FY 1997: \$8000K

Program milestones will be established to ensure that the ISPCT subarea leads to an orderly and rational development of a portfolio of technologies. Currently envisioned program milestones are outlined in Table 4.4.

\subsection{IMPACT OF UNRESOLVED ISSUES}

In concert with this $\mathrm{R} \& \mathrm{D}$, several issues need to be resolved. These issues are critical to the development of in situ technologies. The issue of performance goals must be resolved to support technology development. This involves not only the contaminants of concern but also the treatment efficiency required (e.g., $90 \%$ mass removal vs. $5 \mu \mathrm{g} / \mathrm{L}$ residual concentration). The issue of disrupting the subsurface with physical and/or chemical agents is subject to much debate. While injection of gases, oxidants, and similar materials have occurred at DOE sites (e.g., injection of hydrogen peroxide and grout to the X-231B mixed-waste contaminated unit at the DOE Portsmouth site), there is not widespread acceptance of this ISR approach. Non-acceptance of injection of reactive materials into the subsurface by the regulatory agencies may severely impact the development and deployment of several in situ technologies. Dialogue with regulatory agencies prior to extensive development of in situ technologies requiring the injection of reactive materials would be prudent. Also, the ability to effectively deliver reagents to the subsurface and provide for process monitoring and control are critical to effective development and field-scale implementation of ISPCT technologies.

\subsection{KEY ASSUMPTIONS}

In developing this report and $R \& D$ program, it was assumed that funding would be provided within the ISR IP for a period of 5 years or more and that projects initiated in FY 1993 and beyond would be carried to completion. It was also assumed that unresolved issues would be resolved in a timely fashion so that technology development and mobilization to field scale R\&D could proceed. For example, injection of reactive agents into the subsurface at DOE sites was assumed to be allowed by the regulating community in order to develop and test ISPCT technologies.

\subsection{REGULATIONS AND REQUIREMENTS}

Remediation using ISPCT processes will be subject to the same regulatory requirements as other forms of remediation technology [RCRA, Comprehensive Environmental Response, Compensation, and Liability Act (CERCLA),...]. Regulations on implementation of ISPCT may include those associated with injection of treatment agents into the subsurface (e.g., in situ chemical oxidation) as well as removal of contaminants from the subsurface to aboveground (e.g., vapor extraction). 
Table 4.4. Program milestones for ISPCT technology R\&D.

\begin{tabular}{|c|c|c|c|}
\hline Milestone area & $\begin{array}{l}\text { R\&D } \\
\text { ongoing } \\
\text { within } \\
\text { ISR IP } \\
\end{array}$ & $\begin{array}{l}\text { Target } \\
\text { completion } \\
\text { date }\end{array}$ & Milestone description ${ }^{a}$ \\
\hline Electrokinetics & Yes & $09 / 94$ & $\begin{array}{l}\text { Develop and field test emerging } \\
\text { electrokinetic technologies for } \\
\text { enhancing mobility and removal of (1) } \\
\text { chromium in arid soils and (2) } \\
\text { uranium and mercury from non-arid } \\
\text { unsaturated soils }\end{array}$ \\
\hline $\begin{array}{l}\text { Chemical treatment } \\
\text { barriers }\end{array}$ & Yes & $09 / 95$ & $\begin{array}{l}\text { Develop and field test alternative in } \\
\text { situ treatment barrier concepts for } \\
\text { expanding groundwater plume } \\
\text { boundaries }\end{array}$ \\
\hline $\begin{array}{l}\text { Chemical } \\
\text { oxidation-reduction }\end{array}$ & Yes & $09 / 95$ & $\begin{array}{l}\text { Develop and field test in situ } \\
\text { oxidation-reduction technologies for } \\
\text { treatment of organic compounds, } \\
\text { metals, and radionuclides in soil and } \\
\text { groundwater }\end{array}$ \\
\hline Volatilization & No & $09 / 95$ & $\begin{array}{l}\text { Develop and field test in situ } \\
\text { volatilization technologies enhanced } \\
\text { by thermophysical technologies }\end{array}$ \\
\hline Adsorption & Yes & $09 / 95$ & $\begin{array}{l}\text { Develop and field test in situ sorbent } \\
\text { technologies for groundwater } \\
\text { treatment }\end{array}$ \\
\hline Leaching & No & $09 / 95$ & $\begin{array}{l}\text { Develop and field test in situ leaching } \\
\text { techniques for removal of heavy } \\
\text { metals and radionuclides from soil and } \\
\text { sediments }\end{array}$ \\
\hline Filtration & No & $09 / 96$ & $\begin{array}{l}\text { Develop and field test in situ reactive- } \\
\text { membrane technologies }\end{array}$ \\
\hline Extraction & No & $09 / 97$ & $\begin{array}{l}\text { Develop and field test in situ } \\
\text { supercritical fluid extraction processes }\end{array}$ \\
\hline Combinations & No & $09 / 97$ & $\begin{array}{l}\text { Develop and field test in situ treatment } \\
\text { of groundwater by reactive colloids }\end{array}$ \\
\hline
\end{tabular}

a The information shown was derived from the DOE-complex needs and technology development status; at this time, it is for illustrative purposes only. The order of presentation does not represent the priority of the milestone. This table is undergoing further development and refinement and will be updated annually. 



\section{SOURCE MATERIALS}

The following documents were used in compiling the information in this document.

\subsection{FOR SECTION 1}

1. DOE. 1993. In Situ Remediation Integrated Program Strategic Plan. Predecisional draft. U. S. Department of Energy, Washington, D.C.

\subsection{FOR SECTION 2}

1. Chem-Nuclear Geotech, Inc. 1991. Technology Needs Assessment Interim Report. DOE/ID12584 92, Vol. 1. Prepared by Chem-Nuclear Geotech, Inc. for the Office of Environmental Restoration, U.S. Department of Energy, Washington, D.C.

2. Martin Marietta Energy Systems, Inc. 1993. Oak Ridge K-25 Site Technology Logic Diagram. Prepared for the Office of Technology Development, U.S. Department of Energy.

3. Golchert, N. W., T. L. Duffy, and L. P. Moos. 1991. Argonne National Laboratory-East Site Environmental Report for Calendar Year 1990. U.S. Department of Energy, ANL-91/3. Argonne National Laboratory, Argonne, Ill.

4. DOE. 1991. Environmental Report for 1991, Lawrence Livermore National Laboratory. U.S. Department of Energy, UCRL-50027-91. Lawrence Livermore National Laboratory, Livermore, Calif.

5. EG\&G Rocky Flats. 1989. Rocky Flats Plant Site Environmental Report for 1989. U.S. Department of Energy, RFP-ENV-89. Rocky Flats Plant, Golden, Colo.

6. EG\&G Rocky Flats. 1991. Rocky Flats Plant Site Environmental Report. January through December 1991. U.S. Department of Energy, RFP-ENV-91. Rocky Flats Plant, Golden, Colo.

7. Miltenberger, R. P., B. A. Royce, and J. R. Naidu. 1989. Brookhaven National Laboratory Site Report for Calendar Year 1988. U.S. Department of Energy, BNL-52207. Brookhaven National Laboratory, Brookhaven, Conn.

8. Miltenberger, R. P., B. A. Royce, and J. R. Naidu. 1992. Brookhaven National Laboratory Site Report for Calendar Year 1990. U.S. Department of Energy, BNL-52322. Brookhaven National Laboratory, Brookhaven, Conn.

9. Hoff, D. L., R. G. Mitchell, G. C. Bowman, R. Moore. 1990. The Idaho National Engineering Laboratory Site Environmental Report for Calendar year 1989. U.S. Department of Energy, DOE/ID-12082(89). Idaho National Engineering Lab, Idaho Falls, Idaho.

10. Orr, B. R. and L. D. Cecil. 1991. Hydrologic conditions and distribution of selected chemical constituents in water, Snake River Plain Aquifer, Idaho National Engineering Laboratory, Idaho, 1986-1988. U.S. Department of Energy, DOE/ID-22096. Idaho National Engineering Lab, Idaho Falls, Idaho.

11. Pittman, J. R., R. G. Jensen, and P. R. Fischer. 1988. Hydrologic conditions at the Idaho National Engineering Laboratory, 1982-1985. U.S. Department of Energy, DOE/ID-22078, Idaho National Engineering Lab, Idaho Falls, Idaho.

12. Hoff, D. L., R. G. Mitchell, R. Moore and L. Bingham. 1992. The Idaho National Engineering Laboratory Site Environmental Report for Calendar year 1991. U.S. Department of Energy, DOE/ID-12082(91), Idaho National Engineering Lab, Idaho Falls, Idaho.

13. G.E. Neutron Devices. 1987. Pinellas Plant Environmental Monitoring Report. U.S. Department of Energy, GEPP-EM-1114. Pinellas Plant, Pinellas, Florida.

14. Last, G. V., R. J. Lenhard, B. N. Bjornstad, J. C. Evans, K. R. Roberson, F. A. Spane, J. E. Amonette, M. L. Rockhold. 1991. Characteristics of the Volatile Organic Compounds-Arid Integrated Demonstration Site. (draft, October 1991). U.S. Department of Energy, Pacific Northwest Laboratory, UC-630. 
15. Stenner, R. D., K. H. Cramer, K. A. Higley, S. J. Jette, D. A. Lamar, T. J. McLaughlin, D. R. Sherwood, N. C. Van Houten. 1988. Hazard Ranking System Evaluation of CERCLA Inactive Waste Sites at Hanford, Vol. 2 - Engineered-Facility Sites. U.S. Department of Energy, PNL-6456

16. Jaquish, R. E. and R. W. Bryce (eds.). 1990. Hanford Site Environmental Report for Calendar Year 1989. U.S. Department of Energy, PNL-7346.

17. Byrne, J. M., T. A. Dugan, and J. S. Oberjohn. Feed Materials Production Center Annual Environmental Report for Calendar Year 1990. Westinghouse Materials Company of Ohio, FEMP-2245.

18. Gels, G. L., M. A. Grib, and J. S. Oberjohn. Feed Materials Production Center Environmental Monitoring Annual Report for 1988. Westinghouse Materials Company of Ohio, FEMP--2173.

19. Laseter, W. A. and D. C. Langston. 1988. Environmental Monitoring Report for Pantex Plant Covering 1987. U.S. Department of Energy, MHSMP-88-19.

20. Battelle Pantex. 1992. Pantex Plant Environmental Report for Calendar Year 1991.

21. Kornegay, F. C., D. C. West, G. W. Snyder and M. F. Williams. 1992. Portsmouth Gaseous Diffusion Plant Environmental Report for 1991. ES/ESH-22/V4.

22. Kornegay, F. C., D. C. West, R. A. Evans, M. F. Tardiff, F. D. Adams, P.C. Mucke. 1992. Oak Ridge Reservation Environmental Report for 1991, Volume 1: Narrative, Summary, and Conclusions. ES/ESH-22/V1.

23. Kornegay, F. C., D. C. West, T. G. Jett, and M. F. Williams. Paducah Gaseous Diffusion Plant Environmental Report for 1991. ES/ESH-22/V3.

24. Arnett, M. W., L. K. Karapatakis, A. R. Mamatey, and J. L. Todd. Savannah River Site Environmental Report for 1991. U.S. Department of Energy, WSRC-TR-92-186.

25. Eddy, C. A., B. B. Looney, J. M. Dougherty, T. C. Hazen, and D. S. Kaback. 1991. Characterization of the Geology, Geochemistry, Hydrology and Microbiology of the In Situ Air Stripping Demonstration Site at the Savannah River Site. Westinghouse Savannah River Company, WSRC-RD-91-21.

26. 1991. 1990 Environmental Monitoring Report, Sandia National Laboratories, Albuquerque, New Mexico. DE92-000601.

27. Winogard, I. J. and W. Thordarson. 1975. Hydrogeologic and Hydrochemical Framework, SouthCentral Great Basin, Nevada-California, with Special Reference to the Nevada Test Site. Geological Survey Professional Paper 712-C.

28. 1992. United States Department of Energy Nevada Field Office Environmental Restoration and Waste Management Site Specific Plan, Fiscal Years 1994-1998. DOE/NV-336, UC-900.

29. 1993. Kansas City Plant. Annual Groundwater Monitoring Report for Calendar Year 1992.

\subsection{FOR SECTION 3}

1. Steimle, R. 1992. An inventory of research, laboratory studies and field demonstrations of in situ treatment of contaminated groundwater. Proceedings of the 1992 U.S. EPA/A\&WA International Symposium Pittsburgh, Penn., pp. 84-97.

2. Donehey, A. J., R. B. Piper, R. A. Hyde, M. W. Roy, and S. S. Walker. 1992. In situ physical and chemical treatments. Proceedings of the 1992 U.S. EPA/A\&WMA International Symposium Pittsburgh, Penn., pp. 98-105.

3. de Percin, P. 1992 Application of steam injection/vacuum extraction treatment systems to contaminated soils. Proceedings of the 1992 U.S. EPA/A\&WMA International Symposium Pittsburgh, Penn., pp. 231-234

4. Gural, M.D. and Rivikumar. 1992. Chemical oxidation of pentachlorophenol and trichloroethylene in soil. Proceedings of the 1992 U.S. EPA/A\&WMA International Symposium Pittsburgh, Penn., pp. 319-329.

5. Sresty, G., H. Dev and J. Houthoofd. 1992. In situ soil decontamination by radio frequency heating. Proceedings of the 1992 U.S. EPA/A\&WMA International Symposium Pittsburgh, Penn., pp. 356369. 
6. Banerjee, S. 1992. Application of electrokinetic transport processes to in situ remediation . Proceedings of the 1992 U.S. EPA/A\&WMA International Symposium Pittsburgh, Penn., pp. 370383

7. Nyer, E.K. 1985. Groundwater treatment technology. Van Nostrand Reinhold Inc. New York, New York.

8. Lenhard, R. J., M. A. Gerber, and J. E. Amonette. 1992. Preliminary evaluation of selected in situ remediation technologies for volatile organic compound contamination at arid sites. Pacific Northwest Laboratory Report PNL-8333, UC-630.

9. EPA. 1990. Summary of treatment technology effectiveness for contaminated soil. EPA Office of Emergency Remedial Response. Washington, D. C.

10. EPA. 1992. VISITT--Vendor Information System for Innovative Treatment Technologies. U.S. Environmental Protection Agency, EPA 542-R-92-001, No. 1,.

11. EPA. 1992. The Superfund Innovative Technology Evaluation Program: Technology Profiles Fifth Edition. U.S. Environmental Protection Agency, Office of Solid Waste and Emergency Response, Office of Research and Development. EPA/540/R-92/077. Washington D. C.

12. 1988. NATO/CCMS pilot study: Demonstration of Remedial Action Technologies for Contaminated Land and Groundwater. Second International Workshop, Hamberg, FRG.

13. 1987. NATO/CCMS pilot study: Demonstration of Remedial Action Technologies for Contaminated Land and Groundwater. First International Workshop, Washington D. C.

14. 1991. Synopses of Federal Demonstrations of Innovative Site Remediation Technologies. Prepared by the member agencies of the Federal Remediation Technologies Roundtable, EPA 540-8-91-009.

15. DOE. Basic Research for Environmental Restoration. DOE Five-Year Plan. DOE/ER-0482T. U. S. Department of Energy, Office of Energy Research, Washington, D. C.

16. DOE. 1993. Research in Progress: FY92. Summaries of Projects Sponsored by the Office of Health and Environmental Research. U. S. Department of Energy, Office of Energy Research, Office of Health and Environmental Research. DOE/ER-0592. Washington D. C.

17. DOE. 1993. Office of Technology Development FY 1993 Program Mid-Year Summaries Research, Development, Demonstration, Testing and Evaluation. U. S. Department of Energy. DOE/EM$0110 \mathrm{P}$.

18. 1991. Accessing Federal Data Bases for Contaminated Site Clean-up Technologies. Prepared by the Member Agencies of the Federal Remediation Technologies Roundtable. EPA/540/8-91/008.

19. 1991. Bibliography of Federal Reports and Publications Describing Alternative and Innovative Treatment Technologies for Corrective Action and Site Remediation. Prepared by the Member Agencies of the Federal Technologies Roundtable. EPA540/8-91/007. 


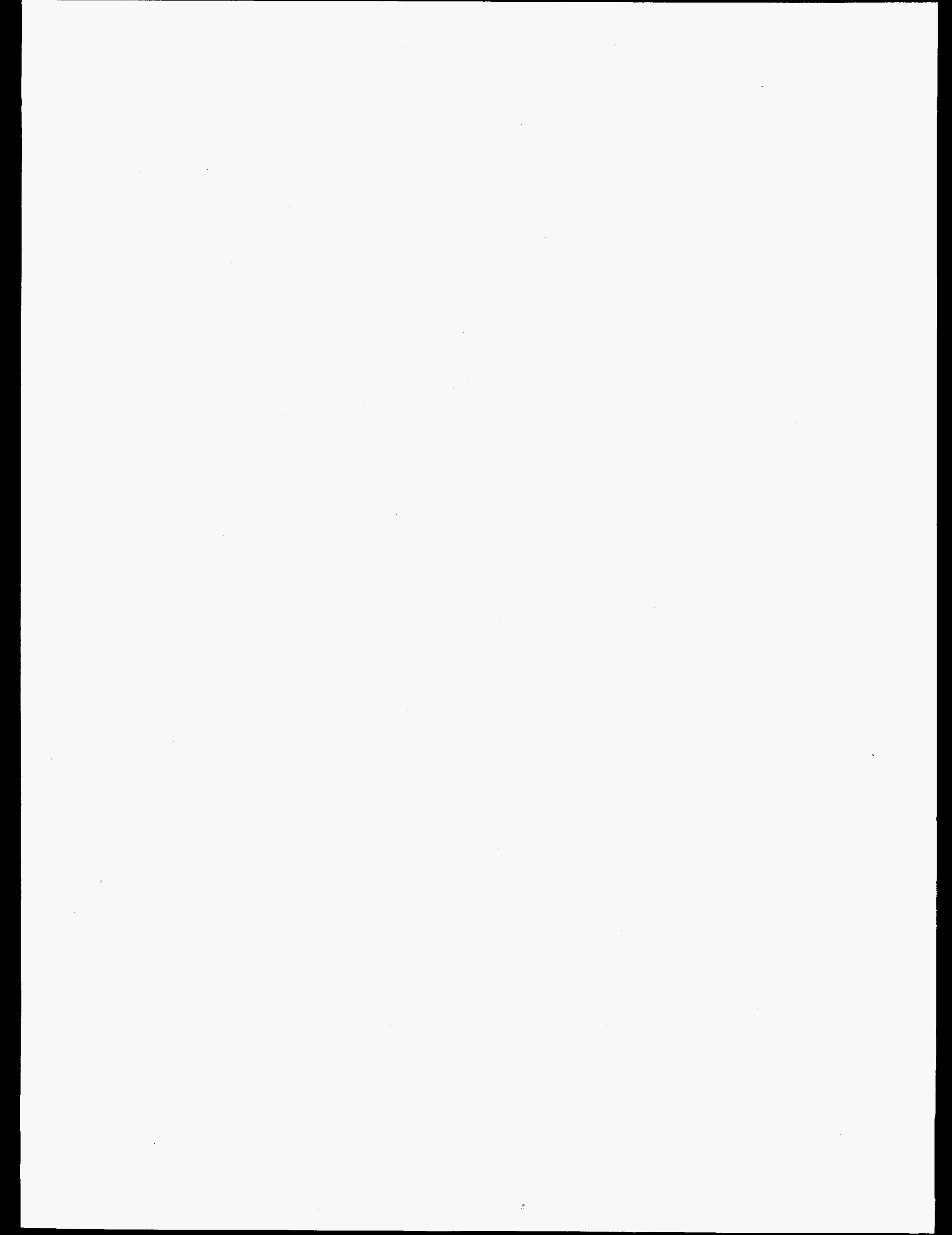




\section{SELECTED BIBLIOGRAPHY}

\subsection{MISCELLANEOUS TECHNICAL PUBLICATIONS AND REPORTS}

1. EPA. 1991. Innovative Treatment Technologies. U. S. Environmental Protection Agency, Office of Solid Waste and Emergency Response, EPA/540/9-91/002. Washington, D. C.,

2. H. Dev, et al., 1989. Radio Frequency Enhanced Decontamination of Soils Contaminated with Halogenated Hydrocarbons. EPA/600/2-89/008, U.S. Environmental Protection Agency, Risk Reduction Engineering Laboratory, Cincinnati, Ohio.

3. EPA. 1992. EPA Handbook Vitrification Technologies for Treatment of Hazardous and Radioactive Waste. EPA/625/R-92/002. U. S. Envirnomental Protection Agency, Office of Research and Development, Cincinnati, Ohio.

4. Y. Acar, et al., 1991. Electrokinetic Soil Processing: Project EKSITE. EK-BR-008-079.

5. Loizidou, M. D. and R. P. Townsend. 1987. Zeolites, Vol. 7. pp. 153

6. Bruell, C. J. and B. A. Segall. 1992. Journal of Environmental Engineering, 118, 1, 68-83

7. Allen G. R. and D. L. Anderson. 1992. Case Study: Vacuum Extraction to Remediate Contaminated Soil--Selection of Optimum Extraction and Emission Control Equipment. Proceedings of the 1992 U.S. EPA/A\&WMA International Symposium on In Situ Treatment of Contaminated Soil and Water. pp. 278-290.

8. Treweek, G. P. and J. Wogec. 1988. Soil remediation by air/steam stripping. Proceeding of the Fifth National Conference of Hazardous Wastes and Hazardous Materials, pp. 147-153.

9. West, O. R., R. L. Siegrist, H. L. Jennings, A. J. Lucero, S. W. Schmunck, and D. W. Greene. 1993. Laboratory Evaluation of In Situ Vapor Stripping. Report from the X-231B Project for In Situ Treatment of Clay Soils Contaminated by Volatile Organic Compounds and Radioactive Substances. Oak Ridge National Laboratory Report, ORNL/TM-12260.

10. Meisinger, R. 1993. Evaluation of $\mathrm{O}_{3}, \mathrm{H}_{2} \mathrm{O}_{2}$, and $\mathrm{KMnO}_{4}$ to Oxidize Hanford Mixed Waste Slurries. Presentation at Third Annual International Symposium on Chemical Oxidation Technology for the Nineties. Vanderbilt University, Nashville, Tenn.

11. Vella, P.A. and B. Veronda. 1993. Oxidation of Trichloroethylene: A Comparison of Potassium Permanganate and Fenton's Reagent. Proceeding of Third Annual International Symposium on Chemical Oxidation Technology for the Nineties. Vanderbilt University, Nashville, Tenn.

12. Gates, D. D. and R. L. Siegrist. 1993. Laboratory evaluation of chemical oxidation using hydrogen peroxide. Report from the X-231B Project for In Situ Treatment of Clay Soils Contaminated by Volatile Organic Compounds and Radioactive Substances. Oak Ridge National Laboratory, ORNL/TM-12259.

13. Gurol, M. D., and J. X. Ravikumar. 1991. Chemical oxidation of hazardous compounds in soil. In Proceedings of National Research and Development Conference on the Control of Hazardous Material. pp. 296-302.

14. Leung, S. W., R. J. Watts, and G. C. Miller. 1992. Degradation of perchloroethylene by Fenton's reagent: Speciation and pathway. Journal of Environmental Quality 21:377-81.

15. Watts, R. J., S. W. Leung, and M. D. Udell. 1991. Treatment of contaminated soils using catalyzed hydrogen peroxide. In Proceedings to the First International Symposium on Chemical Oxidation. Technomic, Nashville, Tenn.

16. 1992. WASTECH '92. Symposium on Innovative Waste Remediation Technology - The State-of-theArt. October 30, 1992, San Diego, Calif. American Academy of Environmental Engineers, Annapolis, Maryland.

17. Beck, D. E. 1993. Review of Sediment and Soils Remediation Techniques for the Paducah Gaseous Diffusion Plant. K/TCD-1085. Oak Ridge K-25 Site, Oak Ridge, Tenn.

18. A Compilation of Technology Development Data Sheets Related to the Field of Environmental Restoration and Waste Management. Prepared by Morgantown Energy Technology Center.

19. Lippold, J. H., and C. R. Ward. 1993. Technical area Status Report for Front-End Waste Handling, Vols. 1 and 2. Draft. (predecisional draft). Prepared for the U. S. Department of Energy, Office of Technology Development, Front-End Handling Technical Support Group, Mixed Waste Integrated Program, under contract DE-AC01-EW30030. 


\subsection{PUBLICATIONS FROM RELEVANT FEDERALLY FUNDED RESEARCH}

\subsubsection{U. S. Department of Energy Published Reports}

1. Characterization of the geology, geochemistry, hydrology and microbiology'of the in-situ air stripping demonstration site at the Savannah River Site. Eddy, C. A., B. B. Looney, J. M. Dougherty, T. C. Hazen, and D. S. Kaback. WSRC-RD-91-21. 1991.

2. Crosshole shear-wave seismic monitoring of an In Situ air stripping waste remediation process. Elbring, G. J. SAND-91-2742. 1992.

3. Full scale field test of the in situ air stripping process at the Savannah River integrated demonstration test site. Looney, B. B., T. C. Hazen, D. S. Kaback, and C. A. Eddy. Westinghouse Savannah River Co., Aiken, So.Car., WSRC-RD-91-22. 1991.

4. Chromate reduction and heavy metal fixation in soil. Schwitzgebel, K. (Sizemore Technical Services, Inc., Round Rock, Tex.), DOE/CH-9214. 1992.

5. Electrokinetic remediation of contaminated soils. Lindgren, E.R., M. W. Kozak, (Sandia National Labs., Albuquerque, New Mex.), and E. D. Mattson (SAT-UNSAT, Inc., Albuquerque, New Mex.), Environmental remediation '91 Conference, Pasco, Wash., 8-11 Sep 1991, SAND-91-0726C. 1991.

6. Electrokinetic remediation of unsaturated soils. Lindgren, E. R. M. W. Kozak, (Sandia National Labs., Albuquerque, New Mex.) and E. D. Mattson, (SAT-UNSAT, Inc., Albuquerque, New Mex.), Industrial and engineering chemistry special symposium of the American Chemical Society, Atlanta, Georgia 21-23 Sep 1992, SAND-92-0817C. 1992.

7. Modeling volatile organic chemical removal by In Situ soil mixing/steam stripping. Gierke, J. S., O. M. Reyes and R. L. Siegrist. CONF-920256-1, National Water Well Association (NWWA) meeting on solving groundwater problems with models, Dallas, Tex., 11-13 Feb 1992. Sponsored by Department of Energy, Washington, DC.

8. Quality Assurance Project Plan for the In Situ soil mixing and physicochemical treatment processes for removal of trichloroethylene and other VOCs from the X-231B Oil Biodegradation Unit. Portsmouth Gaseous Diffusion Plant, Revision 1, Watson, J.S., POEF/ER-4522-Rev.1, 1992.

9. Vitrification of underground storage tanks: Technology development, regulatory issues, and cost analysis. Tixier, J. S. , L. A. Corathers, and L. D. Anderson, PNL-SA-20547, Waste management '92, Tucson, Ariz., 1-5 Mar 1992. Sponsored by Department of Energy, Washington, DC.

10. In Situ vitrification of buried waste: Containment issues and suppression systems. Luey, J. and T. D. Powell, PNL-SA-19974, Waste management '92, Tucson, Ariz., 1-5 Mar 1992. Sponsored, by Department of Energy, Washington, DC.

11. Engineering-scale in situ vitrification of simulated Oak Ridge National Laboratory liquid waste seepage trenches. Peterson, M. E., T. D. Powell, and C. L. Timmerman, PNL-7988, 1992.

12. Vitrified underground barriers. Tixier, J. S., J. A. Stottlemyre, and M. T. Murphy, PNL-SA-19014; CONF-910270-25, Waste management '91, Tucson, Ariz., 24-28 Feb 1991. Sponsored by Department of Energy, Washington, DC.

13. Underground tank remediation by use of In Situ vitrification. Thompson, L. E., PNL-SA-18998, Waste management 91, Tucson, Ariz., 24-28 Feb 1991. Sponsored by Department of Energy, Washington, DC.

14. Innovative developments in In Situ vitrification: Vitrified underground barriers. Thompson, L.E., J. S. Tixier, and M. R. Garnich. (Battelle-Pacific Northwest Lab., Richland, Wash.), American Nuclear Society annual meeting, Boston, Mass., 7-12 Jun 1992, Transactions of the American Nuclear Society, Vol. 65, 1992 pp. 29-30.

15. Demonstration of In Situ vitrification for treatment of radioactively-contaminated soils at Oak Ridge National Laboratory. Spalding, B., G. K. Jacobs, M. T. Naney. (Oak Ridge National Lab., Tenn.); N. E. Dunbar (Univ. of Tennessee, Knoxville, Tenn.) and M. E. Peterson. (Battelle Pacific Northwest Lab., Richland, Wash.), WATTec '92. Innovation in the 21 st century: Excellence through continuous improvement. 19. annual WATTec interdisciplinary technical conference and exhibition, Knoxville, Tenn., 18-21 Feb 1992, Sun Graphics Inc., Oak Ridge, Tenn. 
16. Technical issues associated with In Situ vitrification of the INEL Subsurface Disposal Area. Stoots, C. M., S. O. Bates, R. A. Callow, K. A. Campbell, R. K. Farnsworth, G. K. Krisman, M. G. McKellar, D. F. Nickelson, and C. E. Slater,. EGG-WTD-9985-Vol. 3.

17. In Situ vitrification program at the Idaho National Engineering Laboratory. Loehr, C.A.;and S. K. Merrill. Annual meeting of the American Nuclear Society Conference, Orlando, Flor., 2-6 Jun 1991, Transactions of the American Nuclear Society, Vol. 63,1991 pp. 68-69.

18. Use of noninvasive geophysical techniques for the In Situ Vitrification Program. Josten, N.E., S. T. Marts, and G. S. Carpenter. EGG-WTD-9432-Vol. 1-Rev.1, 1991.

19. Use of noninvasive geophysical techniques for the In Situ Vitrification Program. Marts, S. T., N. E. Josten, and G. S. Carpenter. EGG-WTD-9432-Vol.. 2, 1991.

20. Title: In Situ vitrification program treatability investigation progress report. Arrenholz, D.A. EGGWTD-9383-Rev.1, 1991.

21. Buried waste remediation: A new application for In Situ vitrification. Kindle, C. H., and L. E. Thompson. Report No.: PNL-SA-18804, HAZMACON 91, Santa Clara, Calif., 16-18 Apr 1991. Sponsored by Department of Energy, Washington, DC.

22. In Situ vitrification: Process and products. Kindle, C. and S. Koegler. PNL-SA-18820, Annual meeting and exhibition of the Air and Waste Management Association (AWMA) (84th), Vancouver (Canada), 16-21 Jun 1991. Sponsored by Department of Energy, Washington, DC.

23. In Situ vitrification program treatability investigation progress report. Revision 1, Arrenholz, D. A., EGG-WTD-9383-REV.1, 1991.

24. In Situ vitrification of mixed wastes: Progress and regulatory status. Kindle, C. H. and J. J. Barich. PNL-SA-19218, International mixed waste symposium, Baltimore, MD (United States), 26-29 Aug 1991. Sponsored by Department of Energy, Washington, DC.

25. Potential for using a six-phase alternating current power supply system for In Situ vitrification. Richardson, R. L., PNL-SA-19908, Environmental remediation '91 conference, Pasco, Wash., 8-11 Sep 1991. Sponsored by Department of Energy, Washington, DC.

26. Aqueous dissolution of laboratory and field samples from the in-situ vitrification process. McGrail, B. P., and S. O. Bates, PNL-SA-19786, International conference on the physics of non-crystalline solids (7th), Cambridge, Mass., 4-9 Aug 1991. Sponsored by Department of Energy, Washington, DC.

27. In Situ vitrification of radioactive underground tanks. Koegler, S. S., R. D. Gibby, and L. E. Thompson, PNL-SA-19225, 1991., International waste management conference, Seoul (Korea, Republic of), 21-26 Oct 1991. Sponsored by Department of Energy, Washington, DC.

28. Steady-state analysis of the fate of volatile contaminants during In Situ Vitrification. Kuhn, W. L., PNL-8059.

29. In situ vitrification application to buried waste: Final report of, intermediate field tests at Idaho National Engineering Laboratory (Progress rept). Callow, R. A., J. R. Weidner, C. A. Loehr, S. O. Bates, and L.E. Thompson, EGG-WTD-9807, 1991.

30. Use of noninvasive geophysical techniques for the In Situ Vitrification Program. Volume 2, Demonstration at the simulated waste pit. Marts, S. T., N. E. Josten, and G. S. Carpenter, EGG-WTD9432-Vol. .2.

31. Use of noninvasive geophysical techniques for the In Situ vitrification program. Volume 3, Discussion and recommendations. Josten, N. E., S. T. Marts, and G. S. Carpenter, EGG-WTD-9432-Vol. 3.

32. Technical issues associated with in situ vitrification of the INEL Subsurface Disposal Area. Volume 2, Application of technical issues to the Acid Pit. Stoots, C. M. ,S. O. Bates, R. A. Callow, K. A. Campbell, and R. K. Farnsworth, EGG-WTD-9985-Vol. 2.

33. Use of noninvasive geophysical techniques for the In Situ Vitrification Program. Volume 1, Literature review: Revision 1. Josten, N. E., S. T. Marts, and G. S. Carpenter, EGG-WTD-9432-Vol. 1-Rev. 1.

34. Technical issues associated with $n$ situ vitrification of the INEL Subsurface Disposal Area. Volume 1, A systematic approach for identification, prioritization, and closure of technical issues. Stoots, C. M., S. O. Bates, R. A. Callow, K. A. Campbell, and R. K. Farnsworth, EGG-WTD-9985-Vol. 1, 1991.

35. Technical baseline description for In Situ vitrification laboratory test equipment. Beard, K. V., R. W. Bonnenberg, and L. R. Watson, EGG-WTD-9672, 1991.

36. Underground tank vitrification: Field scale experiments and computational analysis. Tixier, J. S., J. T. Jeffs, and L. E. Thompson, PNL-SA-20543, American Nuclear Society annual meeting, Boston, Mass., 7-12 Jun 1992. Sponsored by Department of Energy, Washington, DC. 
37. In situ vitrification application to buried waste: Interim report of intermediate field tests at Idaho National Engineering Laboratory. Revision 1. Callow, R. A., J. R. Weidner, and L. E. Thompson, EGG-WTD-9422-Rev. 1.

38. Cost performance assessment of In Situ vitrification. Showalter, W. E., B. C. Letellier, S. R. Booth, and P. Barnes-Smith, LA-UR-92-2071; CONF-9206233-1 1992. 16p. Annual army environmental quality R and D symposium (16th), Williamsburg, VA (United States), 23-25 Jun 1992. Sponsored by Department of Energy, Washington, DC.

39. In Situ vitrification on buried waste. Bates, S. O., EGG-M-91481; CONF-920307-83, Waste management '92, Tucson, Ariz., 1-5 Mar 1992. Sponsored by Department of Energy, Washington, DC.

40. Release model for in situ vitrification large-field test off-gas treatment system. Pafford, D. J., and V. X. Tung, EGG-WTD-10129, 1992.

41. Physical and chemical properties of the products of In Situ vitrification engineering tests 5, 6, and 7. Loehr, C. A. and J. R. Weidner, EGG-WTD-9901, 1991.

42. In Situ vitrification: Technology status and a survey of new applications. Thompson, L. E., PNL-SA20508, International specialty conference: in situ treatment of contaminated soil and water, Cincinnati, Ohio, 4-6 Feb 1992. Sponsored by Department of Energy, Washington, DC.

43. Transport and remediation of subsurface contaminants. Sabatini, D.A. and R. C. Knox, (Oklahoma Univ., Norman, Okla., School of Civil Engineering and Environmental Science), 65. annual colloid and surface science symposium Conference Location: Norman, Okla., 17-19 Jun 1991, American Chemical Society, 1992, pp. 71-83.

44. Preliminary evaluation of selected In Situ remediation technologies for Volatile Organic Compound contamination at Arid sites. Lenhard, R. J., M. A. Gerber, and J. E. Amonette, PNL-8333, 1992.

45. Long-Lived Legacy: Managing High-Level and Transuranic Waste at the DOE Nuclear Weapons Complex (Background paper). OTA-BP-O-83, 1991.

46. Early implementation of the Los Alamos National Laboratory Environmental Restoration Program at Technical Area 54. Krueger, J. W., LA-UR-91-1303, Waste management: technology, technology transfer and training, San Juan (Puerto Rico), 24-26 May 1991. Sponsored by Department of Energy, Washington, DC.

47. Innovative technologies and unit operations available for potential In Situ and ex situ treatment of waste and residuals for Hanford single-shell tanks. McLaughlin, T. J., D. A. Lamar, S. J. Phillips, WHC-SA-0999, Waste management '91, Tucson, Ariz., 24-28 Feb 1991. Sponsored by Department of Energy, Washington, DC.

48. Remediation technology needs and applied $R$ and $D$ initiatives. Lien, S. C. T., R. S. Levine, N. J. Beskid, J. S. Devgun, and M. D. Erickson, ANL/CP-72893, Environmental remediation '91 conference, Pasco, Wash., 8-11 Sep 1991.

49. Characterization technologies for environmental remediation. Pruett, J. G., Carribean Haztech conference, San Juan (Puerto Rico), 13-15 Nov 1991.

50. Carbon tetrachloride contamination, 200 West Area, Hanford Site: Arid Site Integrated Demonstration for remediation of volatile organic compounds. Last, G. V., and V. J. Rohay, PNLSA-19564, 1991.

51. Savannah River integrated demonstration program. WSRC-MS-91-290-DRAFT, 1991.

52. Office of Technology Development's integrated program for development of In Situ remediation technologies. Peterson, M. E., M. Shupe, J. Walker, and B. Ellis, PNL-SA-20510; CONF-920307-52, Waste management ' 92 , Tucson, Ariz., 1-5 Mar 1992. Sponsored by Department of Energy, Washington, DC.

53. Sandia National Laboratories Mixed Waste Landfill Integrated Demonstration. Tyler, L. D., J. M. Phelan, N. K. Prindle, S. T. Purvis, and J. C. Stormont, SAND-92-1139C; CONF-920851-24 1992 5 , Spectrum '92: nuclear and hazardous waste management international topical meeting, Boise, Idaho, 23-27 Aug 1992. Sponsored by Department of Energy, Washington, DC.

54. Overview of In Situ waste treatment technologies. Walker, S., R. A. Hyde, R. B. Piper, and M. W. Roy, EGG-M-92342; CONF-920851-57, 1992, 12p, Spectrum '92: nuclear and hazardous waste management international topical meeting. Boise, Idaho, 23-27 Aug 1992. Sponsored by Department of Energy, Washington, DC. 
55. Technical issues associated with in situ vitrification of the INEL Subsurface Disposal Area. Volume 3, Application of technical issues to the TRU-contaminated pits and trenches. Stoots, C. M.,. S. O. Bates, R. A. Callow, K. A. Campbell, and R. K. Farnsworth, EGG-WTD-9985-Vol. 3.

56. Characterization, Monitoring, and Sensor Technology Integrated Program. Poster Session Handout $R \& D / D T \& E$ Mid-Year Program Review, March 22-25, 1993. U.S. Department of Energy, Office of Technology Development Environmental Restoration and Waste Management. DOE/EM-0107P. Bethesda, Maryland.

57. Technical Area Status Report for Chemical/Physical Treatment, Vols. I and II. Brown, C. H., and W. E. Schwinkendorf. Prepared for U. S. Department of Energy, Office of Technology Development, Mixed Waste Integrated Program. under contract DE-AC01-EW30030. 1993.

58. EM-54 Technology Development In Situ Remediation Integrated Program Annual Report. DOE/EM0108P. U. S. Department of Energy, Office of Environmental Restoration and Waste Management, Office of Technology Development. 1993.

\subsubsection{U. S. Environmental Protection Agency Published Reports}

1. Innovative Treatment Technologies: Semi-Annual Status Report (Fourth Edition). Fiedler, L., EPA/542/R-92/011.

2. Technology Assessment of Soil Vapor Extraction and Air Sparging. Loden, M. E. (Camp, Dresser \& McKee, Inc., Cambridge, Mass.), EPA/600/R-92/173, 1992.

3. Procuring Innovative Technologies at Remedial Sites: $Q$ 's and A's and Case Studies. EPA/542/F92/012, 1992.

4. Prospects for In Situ Chemical Treatment for Contaminated Soil. Davila, B., and M. H. Roulier, EPA/600/D-91/285, 1992.

5. In Situ Soil. Flushing. Engineering Bulletin. EPA/540/2-91/021, 1991

6. In Situ Soil Vapor Extraction Treatment. Science Applications International Corp., EPA/540/291/006, 1991.

7. In-situ-soil-vapor-extraction treatment. Engineering Bulletin. Science Applications International Corp, PB-91-228072/XAB, 1991.

8. In Situ Soil Vapor Extraction Treatment; Engineering bulletin. Science Applications International Corp., EPA/540/2-91/006, 1991.

9. In Situ Soil Vapor Extraction Treatment; Engineering bulletin. Science Applications International Corp, EPA/540/2-91/006, 1991.

10. Technology Assessment of Soil Vapor Extraction and Air Sparging. Loden, M. E. (Camp, Dresser and McKee, Inc.), EPA/600/R-92/173, 1992.

11. Air sparging technology evaluation--Proceedings of Research and Development 92 Conference 2. national research and development conference on the control of hazardous materials. Loden, M.E. (Camp Dresser and McKee Inc.); 4-6 Feb 1992, Chiyuan Fan (EPA), 1992.

12. In Situ Steam Extraction Treatment. Science Applications International Corp, EPA/540/2-91/005, 1991.

13. Toxic Treatments 'In-situ' Steam/Hot-Air Stripping Technology. Applications Analysis Report. Jackson, T. (SAIC), EPA/540/A5-90/008, 1991.

14. Soil heating technologies for In Situ treatment: A review--Remedial action, treatment, and disposal of hazardous waste conference 17. Houthoofd, J.M., J. H. McCready, and M. H. Roulier, Annual hazardous waste research symposium, Cincinnati, Ohio, 1991.

15. Demonstration of In Situ steam and hot-air stripping technology. Journal of the Air and Waste Management Association. 41, 1991, de Percin, P.R.

16. Toxic treatments 'in-situ' steam/hot-air stripping technology. Applications analysis report. Jackson, $\mathrm{T}$. (SAIC), PB-91-181768/XAB, 1991.

17. Thermal Desorption Treatment; Engineering bulletin. Oberacker, D., P. Lafornara, P. dePercin, (SAIC), EPA/540/2-91/008, 1991.

18. In-situ steam-extraction treatment. Engineering Bulletin. SAIC, PB-91-228064/XAB, 1991.

19. Comparison of In situ Vitrification and Rotary Kiln Incineration for Soils Treatment. Shearer, T. L., EPA/600/J-91/255, 1991. 
20. Fate of Polychlorinated Biphenyls ( $P C B$ s) in Soil Following Stabilization with Quicklime. Einhaus, $\mathrm{R}$. L., I. Honarkhah, and P. Erickson, (Technology Applications, Inc.), EPA/600/2-91/052, 1991.

21. Toward a better understanding of the complex geochemical processes governing subsurface contaminant transport. Puls, R.W., PB-91-216499/XAB, 1991.

22. Literature Survey of Innovative Technologies for Hazardous Waste Site Remediation 1987-1991. U. S. Environmental Protection Agency, Office of Solid Waste and Emergency Response. EPA/542/B92/004. 1992.

23. Remediation technologies Screening Matrix and Reference Guide. Joint Project of the U.S. EPA and the U. S. Air Force. U. S. EPA Office of Solid Waste and Emergency Response. EPA 542-B-93-005.

24. The Superfund Innovative Technology Evaluation Program, Annual Report to Congress 1992. U.S. EPA Office of Solid Waste and Emergency Response, Office of Research and Development. EPA/540/R-93/525. Washington D. C. 1993

25. The Superfund Innovative Technology Evaluation Program: Technology Profiles Fifth Edition. U.S. Environmental Protection Agency, Office of Solid Waste and Emergency Response, Office of Research and Development. EPA/540/R-92/077. Washington D.C. 1992

26. Abstract Proceedings: Fourth Forum on Innovative Hazardous Waste Treatment Technologies: Domestic and International. U. S. Environmental Protection Agency, Office of Solid Waste and Emergency Response. EPA/540/R-92/081. Washington D. C. 1992

27. Guide to Treatment Technologies for Hazardous Wastes at Superfund Sites. U. S. Environmental Agency, Office of Environmental Engineering and Technology Demonstration. EPA/540/2-89/052. Washington D. C. 1989

28. Compendium of Superfund Program Publications. EPA530-B-92-001. U. S. Environmental Protection Agency, Office of Emergency and Remedial Response. (National Technical Information System?), Washington D. C. 1991

29. Catalogue of Hazardous and Solid Waste Publications. EPA/540/8-91/014. U. S. Environmental Protection Agency, Solid Waste and Emergency Response, Washington D. C. 1992

\subsubsection{U. S. Air Force Published Reports}

1. In Situ Immobilization Of Heavy-Metal-Contaminated Soil: Final Report. Czupryna, G., R. D. Levy, A. I. Maclean, and A. H. Gold. Air Force Engineering And Services Center, Tyndall Air Force Base, Florida. June 1988. AFE-0302-FMI-8472-68; AFESC/ESL-TR-87-17; NTIS: AD-A201 244/XAB

2. Biodegradation and Sorption of Organic Solvents and Hydrocarbon Fuel Constituents in Subsurface Environments. Wilson, J. T., J.M. Henson, and M. D. Slaughter. Air Force Engineering and Services Center, Tyndall Air Force Base,Florida. NTIS: ESL-TR-87-52; AD-A203 753/9/XAD

3. In Situ Decontamination By Radiofrequency Heating -- Field Test. Dev, H., J. Enk, G. Stresty, J. Bridges, and D. Downy, September 1989. NTIS: ESL-TR-88-62; AD-A221 186/0/XAB

4. Vapor Phase Catalytic Oxidation of Mixed Volatile Organic Compounds. Greene, H. University Of Akron, Akron, Ohio, September 1989. NTIS: ESL-TR-89-12.

\subsubsection{U. S. Army Published Reports}

1. Demonstration of Thermal Stripping of JP-4 and Other VOCs from Soils at Tinker Air Force Base, Oklahoma City, Ok: Final Report, U S Army Toxic An Hazardous Materials Agency. March 1990. USATHAMA: CETHA-TS-CR-90026

2. Economic Evaluation of Low Temperature Thermal Stripping of Volatile Organic Compounds from Soil: Technical Report. Marks, P. J. And J. W. Noland. U S Army Toxic And Hazardous Materials Agency. August 1986. USATHAMA: AMXTH-TE-CR-86085

3. Pilot Investigation of Low Temperature Themal Stripping of Volatile Organic Compounds from Soil. U S Army Toxic and Hazardous Materials Agency. Task 11. June 1986. USATHAMA: AMXTHTE-TR-86074

4. Arsenic Contaminated Treatment Pilot Study at the Sharpe Army Depot Lathrope, CA: Final Report. U S Army Toxic And Hazardous Materials Agency. December 1990. USATHAMA: CETHA-TS90184 
APPENDICES 



\section{APPENDIX A: TECHNOLOGY DEVELOPMENT AND COMMERCIALIZATION}

Tables A.1 to A.3 are each divided into six categories: technology and vendor or developer, status, waste media (contaminants), capacity and cost, program, and comments. The definitions of each category are listed and discussed here. Technology includes the following features: separation and transfer, destruction, and immobilization. In this survey, vendors from private sectors and developers from government agencies and laboratories who have developed and fully tested a technology were included. The status of each technology refers to the development status of an physical/chemical treatment technology and comprises three categories: bench scale (B), a technology shown to be feasible with bench-top equipment in the laboratory, but available data cannot be used to develop field-scale use in the absence of additional pilot-scale experience for similar applications; pilot scale $(\mathrm{P})$, technology for which available equipment is of sufficient size to verify technology feasibility and establish the design and operating conditions for the field-scale system; and field scale (F), technology for which available equipment is sized and commercially available for actual site remediation.

The waste media refers to the actual or potential types of media treated: soil, sludge, solid, and groundwater. The contaminants include VOCs, solvents, heavy metals, radioactive metals, polycyclic aromatic hydrocarbons (PAHs), polychlorinated biphenyls (PCBs), etc. Capacity and cost are listed as given by vendors or developers; attempts are not made to normalize them. The costs vary considerably because some included capital cost and others considered only the maintenance cost. The program refers to an innovative technology demonstration program sponsored by a federal agency under which the technology is developed. If a program is not identified, the box was left blank. Finally, the comments include either highlights of the technology or limitations of the technology. 
Table A.1 Reported stage-of-development information for ISPCT technologies that rely on contaminant-transfer processes.

\begin{tabular}{|c|c|c|c|c|c|}
\hline $\begin{array}{l}\text { Technology and } \\
\text { vendor or developer }\end{array}$ & Status ${ }^{a}$ & $\begin{array}{l}\text { Waste media } \\
(\text { contaminants) } b\end{array}$ & $\begin{array}{c}\text { Capacity and } \\
\text { cost } \\
\end{array}$ & Program $^{c}$ & Comments \\
\hline \multicolumn{6}{|l|}{ Adsorption } \\
\hline $\begin{array}{l}\text { Dynaphore, Inc. } \\
(804)-672-3464\end{array}$ & $\mathrm{P}$ & $\begin{array}{l}\text { groundwater } \\
\text { (heavy metals, } \\
\text { radioactive metals) }\end{array}$ & $\begin{array}{l}100-10,000 \\
\mathrm{gal} / \mathrm{h} \\
\$ 0.001- \\
0.02 / \mathrm{gal}\end{array}$ & SITE & $\begin{array}{l}\text { For low oily } \\
\text { substance and } \\
\text { moderate } \\
\text { concentration; } 3 \\
\text { times deduction } \\
\end{array}$ \\
\hline $\begin{array}{l}\text { Environmental Fuel } \\
\text { Systems, Inc. } \\
(512)-796-7767\end{array}$ & $\mathrm{~F}$ & $\begin{array}{l}\text { groundwater/soil } \\
\text { (VOCs, solvents) }\end{array}$ & $\begin{array}{l}\$ 0.4-4 / \mathrm{gal} \\
20-2000 \mathrm{~g} / \mathrm{h}\end{array}$ & & $\begin{array}{l}\text { Concentrate and } \\
\text { absorb VOCs, depend } \\
\text { on permeability, } \\
\text { VOC pressure, and } \\
\text { concentration }\end{array}$ \\
\hline $\begin{array}{l}\text { EPS Environmental, } \\
\text { Inc. (201)-368-7902 }\end{array}$ & $\mathrm{F}$ & $\begin{array}{l}\text { soil/solid/sludge } \\
\text { (mercury) }\end{array}$ & NA & & $\begin{array}{l}\text { Absorb mercury } \\
\text { vapor }\end{array}$ \\
\hline \multicolumn{6}{|l|}{ Volatilization } \\
\hline $\begin{array}{l}\text { Accutech Remedial } \\
\text { Systems, Inc. } \\
(908)-739-6444\end{array}$ & $\mathrm{~F}$ & $\begin{array}{l}\text { soil } \\
\text { (VOCs) }\end{array}$ & NA & SITE & $\begin{array}{l}\text { Pneumatic fracturing } \\
\text { extraction and } \\
\text { catalytic oxidation }\end{array}$ \\
\hline $\begin{array}{l}\text { Billings and } \\
\text { Associates, Inc. } \\
(505)-345-1116\end{array}$ & $\mathrm{~F}$ & $\begin{array}{l}\text { soil/sludge } \\
\text { (gasoline, diesel } \\
\text { fuels, and } \\
\text { halogenated } \\
\text { organics) }\end{array}$ & $\mathrm{NA}$ & SITE & $\begin{array}{l}\text { Soil vacuum } \\
\text { extraction combined } \\
\text { with in situ } \\
\text { biodegradation }\end{array}$ \\
\hline $\begin{array}{l}\text { Battelle, PNL } \\
(509)-376-0554\end{array}$ & B & $\begin{array}{l}\text { soil/sludge } \\
\text { (VOCs, PAHs, } \\
\text { solvents) }\end{array}$ & NA & & $\begin{array}{l}\text { Thermally enhanced } \\
\text { soil-vapor extraction }\end{array}$ \\
\hline $\begin{array}{l}\text { EM\&C Engineering } \\
\text { Associates } \\
(714)-957-6429\end{array}$ & $\mathbf{P}$ & $\begin{array}{l}\text { soil/solid/sludge } \\
\text { (VOCs, PAHs, } \\
\text { solvents) }\end{array}$ & $\mathrm{NA}$ & & Steam injection \\
\hline $\begin{array}{l}\text { EM\&C Engineering } \\
\text { Associates } \\
(714)-957-6429\end{array}$ & $\mathrm{~B}$ & $\begin{array}{l}\text { soil/solid/sludge } \\
\text { (organics) }\end{array}$ & NA & & $\begin{array}{l}\text { Use of in situ down- } \\
\text { hole burners }\end{array}$ \\
\hline $\begin{array}{l}\text { Groundwater } \\
\text { Technology, Inc. } \\
(609)-587-0300\end{array}$ & $\mathrm{~F}$ & $\begin{array}{l}\text { groundwater } \\
\text { (VOCs, solvents) }\end{array}$ & $\begin{array}{l}\$ 40-70 / \mathrm{yd}^{3} \\
10-100 \mathrm{lb} / \mathrm{h}\end{array}$ & & Air sparging \\
\hline $\begin{array}{l}\text { Halliburton NUS } \\
(713)-492-1888\end{array}$ & $\mathbf{F}$ & $\begin{array}{l}\text { soil/groundwater } \\
\text { VOCs }\end{array}$ & NA & & $\begin{array}{l}\text { In situ air stripping or } \\
\text { sparging combined } \\
\text { with in situ } \\
\text { biodegradation }\end{array}$ \\
\hline $\begin{array}{l}\text { Hughes Environmental } \\
\text { Systems, Inc. } \\
\text { (714)-536-6547 }\end{array}$ & $\mathrm{F}$ & $\begin{array}{l}\text { soil/groundwater } \\
\text { (VOCs, SVOCs, } \\
\text { gasoline, diesel } \\
\text { fuels, solvents) }\end{array}$ & NA & SITE & $\begin{array}{l}\text { Steam injection } \\
\text { coupled with } \\
\text { recovery; oxidation } \\
\text { processes }\end{array}$ \\
\hline $\begin{array}{l}\text { Hill Air Force Base } \\
\text { Demonstration } \\
(504)-283-4628 \\
\end{array}$ & $\mathrm{~F}$ & $\begin{array}{l}\text { soil } \\
\text { (fuels and TCE) }\end{array}$ & $\$ 15-85 /$ ton & AFESC & $\begin{array}{l}\text { Soil venting, up to } 40 \\
\text { ft for permeable soil }\end{array}$ \\
\hline
\end{tabular}


Table A.1 Reported stage-of-development information for ISPCT technologies that rely on contaminant-transfer processes (continued).

\begin{tabular}{|c|c|c|c|c|c|}
\hline $\begin{array}{l}\text { Technology and } \\
\text { vendor or developer }\end{array}$ & Status $^{a}$ & $\begin{array}{l}\text { Waste media } \\
\text { (contaminants) }^{b}\end{array}$ & $\begin{array}{c}\text { Capacity and } \\
\text { cost } \\
\end{array}$ & Program $^{c}$ & Comments \\
\hline \multicolumn{6}{|c|}{ Volatilization (cont.) } \\
\hline $\begin{array}{l}\text { Illinois Institute of } \\
\text { Technology Research } \\
\text { Institute./Halliburton } \\
\text { NUS } \\
\text { (615)-483-9900 }\end{array}$ & $\mathrm{F}$ & $\begin{array}{l}\text { soil } \\
\text { (VOCs, SVOCs) }\end{array}$ & NA & SITE & $\begin{array}{l}\text { Radio-frequency } \\
\text { heating to volatilize } \\
\text { organic contaminants } \\
\text { from soil in vadose } \\
\text { zone }\end{array}$ \\
\hline $\begin{array}{l}\text { IIT Research Institute, } \\
\text { USA }\end{array}$ & $P$ & $\begin{array}{l}\text { soil } \\
\text { (solvents, gasoline- } \\
\text { kerosene mixture) }\end{array}$ & NA & $\begin{array}{l}\text { NATO/ } \\
\text { CCMS }\end{array}$ & $\begin{array}{l}\text { Using radio- } \\
\text { frequency heating to } \\
\text { remove hydrocarbons }\end{array}$ \\
\hline $\begin{array}{l}\text { Lawrence Livermore } \\
\text { National Laboratory }\end{array}$ & $\mathrm{P}$ & $\begin{array}{l}\text { soil } \\
\text { (gasoline) }\end{array}$ & NA & $\mathrm{RD} \& \mathrm{D}$ & $\begin{array}{l}\text { Vacuum extraction } \\
\text { with thermal oxidizer }\end{array}$ \\
\hline $\begin{array}{l}\text { NOVA Terra } \\
(213)-328-9433\end{array}$ & $\mathrm{~F}$ & $\begin{array}{l}\text { soil/solid } \\
\text { (VOCs, PAHs, } \\
\text { solvents) }\end{array}$ & $\begin{array}{l}5-20 \mathrm{yd}^{3} / \mathrm{h} \\
\$ 100- \\
300 / \mathrm{yd}^{3} \\
\end{array}$ & SITE & $\begin{array}{l}\text { Steam and hot air; up } \\
\text { to } 30 \mathrm{ft} \text { deep }\end{array}$ \\
\hline $\begin{array}{l}\text { Oak Ridge National } \\
\text { Laboratory }\end{array}$ & $\mathrm{F}$ & $\begin{array}{l}\text { soil } \\
\text { (VOCs) }\end{array}$ & $\begin{array}{l}15-40 \mathrm{yd}^{3} / \mathrm{h} \\
\$ 150- \\
200 / \mathrm{yd}^{3}\end{array}$ & RD\&D & $\begin{array}{l}\text { Ambient and hot air; } \\
\text { mixed regions up to } \\
40 \mathrm{ft} \text { deep }\end{array}$ \\
\hline $\begin{array}{l}\text { Terra Vac } \\
(609)-530-0003\end{array}$ & $\mathrm{~F}$ & $\begin{array}{l}\text { soil/sludge } \\
\text { (VOCs, PAHs, } \\
\text { solvents) } \\
\end{array}$ & $\$ 10-100 /$ ton & SITE & $\begin{array}{l}\text { Vapor extraction } \\
\text { with low vacuum; for } \\
\mathrm{H}>0.0001\end{array}$ \\
\hline $\begin{array}{l}\text { Toxic Treatments, Inc. } \\
\text { (415)-391-2113 }\end{array}$ & $\mathrm{P}$ & $\begin{array}{l}\text { soil } \\
\text { (VOCs) }\end{array}$ & NA & SITE & $\begin{array}{l}\text { Steam/air stripping; } \\
\text { up to } 27 \mathrm{ft}\end{array}$ \\
\hline $\begin{array}{l}\text { Twin Cities Army } \\
\text { Ammunition Plant } \\
(301)-671-2054\end{array}$ & $\mathrm{P}$ & $\begin{array}{l}\text { soil } \\
\text { (VOCs) }\end{array}$ & $\$ 15-85 /$ ton & USAEC & $\begin{array}{l}\text { Soil venting with } \\
\text { vacuum; up to } 40 \mathrm{ft} \\
\text { for permeable soil }\end{array}$ \\
\hline $\begin{array}{l}\text { Udell Technologies, } \\
\text { Inc. } \\
\text { (415)-653-9477 }\end{array}$ & $\mathrm{F}$ & $\begin{array}{l}\text { soil/sludge } \\
\text { (VOCs, PCBs, } \\
\text { PAHs, solvents }\end{array}$ & $\$ 50-125 / \mathrm{yd}^{3}$ & SITE & $\begin{array}{l}\text { Steam injection, } \\
\text { vacuum extraction; } \\
\text { up to } 90 \mathrm{ft}\end{array}$ \\
\hline $\begin{array}{l}\text { Western Research } \\
\text { Institute } \\
\text { (307)-721-2281 }\end{array}$ & $\mathrm{P}$ & $\begin{array}{l}\text { soil } \\
\text { (light and dense } \\
\text { organic liquids, } \\
\text { petroleum by- } \\
\text { products) }\end{array}$ & $\mathrm{NA}$ & SITE & $\begin{array}{l}\text { Steam and hot water } \\
\text { injection; may be } \\
\text { coupled with } \\
\text { biological treatment }\end{array}$ \\
\hline $\begin{array}{l}\text { Westinghouse } \\
\text { Savannah River Co. } \\
\text { (803)-725-5190 }\end{array}$ & $\mathbf{P}$ & $\begin{array}{l}\text { soil/groundwater } \\
\text { (VOCs, TCE, PCE) }\end{array}$ & $\begin{array}{l}\$ 20 / \mathrm{b}, \\
\text { capital } \\
\$ 500 \mathrm{~K} \text { to } \\
650 \mathrm{~K}\end{array}$ & RD\&D & $\begin{array}{l}\text { Air stripping with } \\
\text { horizontal wells; } \\
\text { good for high } \\
\text { permeability }\end{array}$ \\
\hline \multicolumn{6}{|l|}{ Ion Exchange } \\
\hline $\begin{array}{l}\text { Scientific Ecology } \\
\text { Group, Inc. } \\
\text { (412)-247-6255 }\end{array}$ & B & $\begin{array}{l}\text { soil (heavy metals, } \\
\text { radionuclides) }\end{array}$ & NA & & $\begin{array}{l}\text { Cation exchange; } \\
\text { avoid low } \\
\text { permeability }\end{array}$ \\
\hline
\end{tabular}


Table A.1 Reported stage-of-development information for ISPCT technologies that rely on contaminant-transfer processes (continued).

\begin{tabular}{|c|c|c|c|c|c|}
\hline $\begin{array}{l}\text { Technology and } \\
\text { vendor or developer }\end{array}$ & Status $^{a}$ & $\begin{array}{l}\text { Waste media } \\
\text { (contaminants) } b\end{array}$ & $\begin{array}{c}\text { Capacity and } \\
\text { cost }\end{array}$ & Program $^{c}$ & Comments \\
\hline \multicolumn{6}{|l|}{ Electrokinetics } \\
\hline $\begin{array}{l}\text { Electrokinetics, Inc. } \\
\text { (504)-388-3992 }\end{array}$ & $P$ & $\begin{array}{l}\text { soil/sludge (metals, } \\
\text { VOCs, } \\
\text { radionuclides) }\end{array}$ & $\begin{array}{l}50-100 \mathrm{yd}^{3} / \mathrm{h} \\
\$ 90-140 / \mathrm{yd}^{3}\end{array}$ & SITE & $\begin{array}{l}\text { Use of DC current; } \\
\text { not good for mixtures }\end{array}$ \\
\hline $\begin{array}{l}\text { Andco Environmental } \\
\text { Processes, Inc. } \\
\text { (716)-691-2100 }\end{array}$ & $\mathrm{P}$ & $\begin{array}{l}\text { groundwater } \\
\text { (chromium and } \\
\text { other heavy metals) }\end{array}$ & $\begin{array}{l}50-120 \\
\mathrm{gal} / \mathrm{min}\end{array}$ & SITE & $\begin{array}{l}\text { Electrochemical } \\
\text { reactions to generate } \\
\text { ions for reduction of } \\
\text { metals }\end{array}$ \\
\hline $\begin{array}{l}\text { Isotron Corporation } \\
\text { (504)-254-4624 }\end{array}$ & $\mathrm{P}$ & $\begin{array}{l}\text { soil/sludge } \\
\text { /groundwater } \\
\text { (metals, } \\
\text { radionuclides) }\end{array}$ & NA & & $\begin{array}{l}\text { Use of DC current; } \\
\text { not good for } \\
\text { uncharged organics }\end{array}$ \\
\hline \multicolumn{6}{|l|}{ Combinations } \\
\hline $\begin{array}{l}\text { Waste-Tech Services, } \\
\text { Inc. } \\
\text { (303)-279-9712 }\end{array}$ & $P$ & soil (PCBs, PAHs) & $\$ 75-200 / \mathrm{yd}^{3}$ & & $\begin{array}{l}\text { For shallow aquifer; } \\
\text { oil removal by } \\
\text { alkaline-polymer- } \\
\text { surfactant agents }\end{array}$ \\
\hline $\begin{array}{l}\text { Soestduinen, the } \\
\text { Netherlands }\end{array}$ & & soil (cadmium) & NA & $\begin{array}{l}\text { NATO } \\
\text { /CCMS }\end{array}$ & $\begin{array}{l}\text { Infiltration of acid, } \\
\text { water, withdrawal of } \\
\text { percolate, water } \\
\text { treatment by ion- } \\
\text { exchange } \\
\end{array}$ \\
\hline $\begin{array}{l}\text { Geochem } \\
\text { (303)-988-8902 }\end{array}$ & $\mathrm{P}$ & $\begin{array}{l}\text { groundwater } \\
\text { (metals, arsenic, } \\
\text { cyanides) }\end{array}$ & NA & & $\begin{array}{l}\text { Precipitation, ion- } \\
\text { exchange, and } \\
\text { sorption }\end{array}$ \\
\hline \multicolumn{6}{|l|}{ Magnetic } \\
\hline $\begin{array}{l}\text { S.G.Frantz Co., Inc. } \\
(609)-882-7100\end{array}$ & B & $\begin{array}{l}\text { soil/solid/sludge } \\
\text { (metals, } \\
\text { radionuclides) }\end{array}$ & $\begin{array}{l}0.05-2 \text { tons/h } \\
\$ 6-6000 / \text { ton }\end{array}$ & & $\begin{array}{l}\text { For dry powder; } \\
\text { avoid oily substance } \\
\text { and moisture }\end{array}$ \\
\hline
\end{tabular}

a $\quad \mathrm{B}$ : bench scale or emerging

P: pilot scale

F: field scale.

$b$ VOCs: volatile organic compounds

SVOCs: semivolatile organic compounds

PAHs: polycyclic aromatic hydrocarbons

c AFESC: Air Force Engineering and Services Center (administrated by U.S. Air Force)

RD\&D: Research, Development and demonstration (administrated by DOE)

NATO/CCMS: North Atlantic Treaty Organization/Committee on Challenges to Modern Society

SITE: Superfund Innovative Technology Evaluation (administrated by EPA)

USAEC: U.S. Army Environmental Center (administrated by U.S. Army Corps of Engineers,

formerly the U.S. Army Toxic and Hazardous Materials Agency, USATHAMA)

NA: not available 
Table A.2. Reported stage-of-development information for ISPCT technologies that rely on destruction processes.

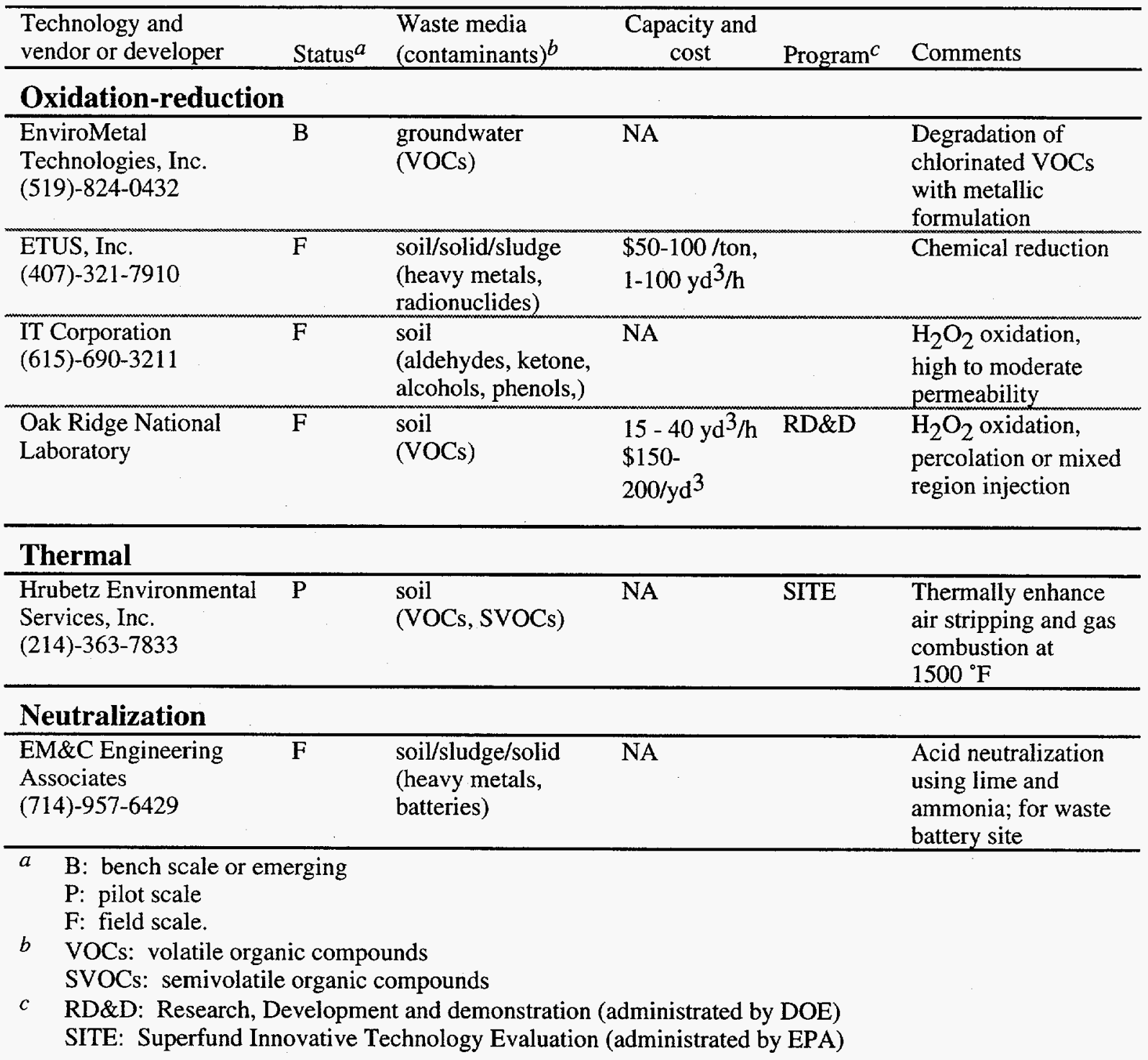

NA: not available 
Table A.3. Reported stage-of-development information for ISPCT technologies that rely on immobilization processes.

\begin{tabular}{|c|c|c|c|c|c|}
\hline $\begin{array}{l}\text { Technology and } \\
\text { vendor or developer }\end{array}$ & Status $^{a}$ & $\begin{array}{l}\begin{array}{l}\text { Waste media } \\
\text { (contaminants) }^{b}\end{array} \\
\end{array}$ & $\begin{array}{c}\text { Capacity and } \\
\text { cost } \\
\end{array}$ & Program $^{c}$ & Comments \\
\hline \multicolumn{6}{|l|}{ Cryogenic } \\
\hline $\begin{array}{l}\text { Layne-Northwest } \\
\text { Company } \\
\text { (414)246-4646 } \\
\end{array}$ & $\mathrm{P}, \mathrm{F}$ & soil & & none & \\
\hline \multicolumn{6}{|l|}{ Grouting } \\
\hline $\begin{array}{l}\text { GKN Keller GmbH } \\
\text { Hamburg, FRG }\end{array}$ & $?$ & $\begin{array}{l}\text { soil } \\
\text { (phenols) }\end{array}$ & NA & $\begin{array}{l}\text { NATO/ } \\
\text { CCMS }\end{array}$ & $\begin{array}{l}\text { Soil/water treatment } \\
\text { by oxidation, jet } \\
\text { grouting in peat } \\
\text { layers }\end{array}$ \\
\hline \multicolumn{6}{|l|}{ Vitrification } \\
\hline $\begin{array}{l}\text { Contamination Control } \\
\text { Services, Inc. } \\
(803)-859-2048 \\
\end{array}$ & B & $\begin{array}{l}\text { soil/solid/sludge } \\
\text { (metals, } \\
\text { radionuclides) } \\
\end{array}$ & $\begin{array}{l}\$ 425-500 \\
/ \text { ton }\end{array}$ & & $\begin{array}{l}\text { For non-volatile } \\
\text { compounds }\end{array}$ \\
\hline $\begin{array}{l}\text { Pacific Northwest } \\
\text { Laboratory } \\
(509)-376-0492\end{array}$ & F & $\begin{array}{l}\text { soil } \\
\text { (organic and } \\
\text { inorganic } \\
\text { compounds and } \\
\text { radionuclides) } \\
\end{array}$ & $\begin{array}{l}\$ 150-350 \\
/ \text { ton } \\
100 \text { tons/d }\end{array}$ & RD\&D & $\begin{array}{l}\text { Converting } \\
\text { contaminated soil to } \\
\text { glass through melting } \\
\text { the soil by joule } \\
\text { heating }\end{array}$ \\
\hline $\begin{array}{l}\text { Battelle Pacific } \\
\text { Northwest Lab, USA }\end{array}$ & $?$ & $\begin{array}{l}\text { soil } \\
\text { (PCBs) } \\
\end{array}$ & NA & $\begin{array}{l}\text { NATO/ } \\
\text { CCMS } \\
\end{array}$ & $\begin{array}{l}\text { Complete pyrolysis } \\
\text { of organic substances }\end{array}$ \\
\hline $\begin{array}{l}\text { Bio-electrics, Inc. } \\
(816)-474-4895\end{array}$ & $\mathrm{P}$ & $\begin{array}{l}\text { soil/solid/sludge } \\
\text { (organic } \\
\text { compounds, metals, } \\
\text { radionuclides) }\end{array}$ & $\begin{array}{l}\$ 100-400 \\
/ \text { ton } \\
2000-3000 \\
1 \mathrm{~b} / \mathrm{h}\end{array}$ & & $\begin{array}{l}\text { Volatilize, } \\
\text { decompose, and } \\
\text { vitrify organic } \\
\text { compounds; not for } \\
\text { underwater sediment }\end{array}$ \\
\hline $\begin{array}{l}\text { Geosafe Corporation } \\
(509)-375-3268\end{array}$ & $F$ & $\begin{array}{l}\text { soil/solid/sludge } \\
\text { (organic } \\
\text { compounds, metals, } \\
\text { radionuclides) }\end{array}$ & $\begin{array}{l}\$ 300-500 \\
/ \text { ton } \\
4-6 \text { tons } / \mathrm{h}\end{array}$ & SITE & $\begin{array}{l}\text { Melting contaminated } \\
\text { solid, organic } \\
\text { decomposition by } \\
\text { pyrolysis; for }<10 \% \\
\text { organic } \\
\end{array}$ \\
\hline $\begin{array}{l}\text { EM\&C Engineering } \\
\text { Associates } \\
\text { (714)-957-6429 }\end{array}$ & B & $\begin{array}{l}\text { soil/solid/sludge } \\
\text { (metals, organic } \\
\text { compounds } \\
\text { radionuclides) } \\
\end{array}$ & NA & & $\begin{array}{l}\text { Operated at low } \\
\text { temperature }\end{array}$ \\
\hline \multicolumn{6}{|l|}{ Solidification } \\
\hline $\begin{array}{l}\text { Hazardous Waste } \\
\text { Control } \\
(203)-366-7020 \\
\end{array}$ & $F$ & $\begin{array}{l}\text { soil } \\
\text { (metals, sulfates, } \\
\text { nitrates) } \\
\end{array}$ & NA & SITE & $\begin{array}{l}\text { Use specially } \\
\text { formulated cements, } \\
\text { sands and aggregates } \\
\end{array}$ \\
\hline $\begin{array}{l}\text { International Waste } \\
\text { Technologies } \\
\text { (316)-269-2660 }\end{array}$ & $\mathrm{P}$ & $\begin{array}{l}\text { soil/solid/sludge } \\
\text { (organic compounds } \\
\text { and metals) }\end{array}$ & $\$ 194 /$ ton & SITE & $\begin{array}{l}\text { Used proprietary } \\
\text { treatment chemicals } \\
\text { to create a crystalline } \\
\text { inorganic polymer }\end{array}$ \\
\hline
\end{tabular}


Table A.3. Reported stage-of-development information for ISPCT technologies that rely on immobilization processes (continued).

\begin{tabular}{|c|c|c|c|c|c|}
\hline \multirow{2}{*}{$\begin{array}{l}\text { Technology and } \\
\text { vendor or developer } \\
\text { Solidification (cont. }\end{array}$} & Status ${ }^{a}$ & $\begin{array}{l}\text { Waste media } \\
\text { (contaminants) }\end{array}$ & $\begin{array}{l}\text { Capacity and } \\
\text { cost }\end{array}$ & Program $c$ & Comments \\
\hline & & & & & \\
\hline $\begin{array}{l}\text { Millgard Environmental } \\
\text { Corporation / Chemical } \\
\text { Waste Management, Inc. }\end{array}$ & F & $\begin{array}{l}\text { soil } \\
\text { (VOCs, metals) }\end{array}$ & $\begin{array}{l}15-40 \mathrm{yd}^{3} / \mathrm{h} \\
\$ 150- \\
200 / \mathrm{yd}^{3}\end{array}$ & RD\&D & $\begin{array}{l}\text { Grout injection } \\
\text { during soil mixing }\end{array}$ \\
\hline $\begin{array}{l}\text { S.M.W. Seiko, Inc. } \\
(415)-591-9646\end{array}$ & $\bar{P}$ & $\begin{array}{l}\text { soil } \\
\text { (metals and } \\
\text { semivolatile } \\
\text { organic } \\
\text { compounds) }\end{array}$ & $90-140 \mathrm{yd}^{3} / \mathrm{d}$ & SITE & $\begin{array}{l}\text { Inject solidification } \\
\text { and stabilization } \\
\text { agents to form } \\
\text { monolithic block; up } \\
\text { to } 100 \mathrm{ft}\end{array}$ \\
\hline \multicolumn{6}{|c|}{$\begin{array}{l}\text { B: bench scale or emerging } \\
\text { P: pilot scale } \\
\text { F: full scale. }\end{array}$} \\
\hline \multicolumn{6}{|c|}{$\begin{array}{l}b \text { VOCs: volatile organic compounds } \\
\text { SVOCs: semivolatile organic compounds }\end{array}$} \\
\hline \multicolumn{6}{|c|}{$\begin{array}{l}\text { C RD\&D: Research, Development and demonstration (administrated by DOE) } \\
\text { NATO/CCMS: North Atlantic Treaty Organization/Committee on Challenges to Modern Society } \\
\text { SITE: Superfund Innovative Technology Evaluation (administrated by EPA) }\end{array}$} \\
\hline
\end{tabular}





\section{APPENDIX B:}

\section{OTHER RELEVANT R\&D PROGRAMS}

A number of research projects are ongoing within the DOE Office of Technology Development (OTD) that are presently directed at developing physical/chemical treatments for in situ use, or could possibly be modified for in situ use. The technical task plans (TTPs) can be divided into six major categories: removal of VOCs, development of horizontal well technologies, destruction of VOCs, thermal enhancement of vapor extraction, stabilization of metals and radioactive nuclides, and removal of metals and radioactive nuclides. Three active projects were identified that are evaluating and developing in situ VOC stripping methods. These TTPs were conducted to improve, model, or determine cost of stripping of VOCs from the subsurface. Three TTPs were identified as developing horizontal well techniques. Horizontal wells are used in three industries: petroleum, pipeline, and utility (e.g., telephone). These TTPs either compared directional drilling technology of the three industries or evaluated its use in different types of soils (arid and non-arid). Four TTPs were identified that developed efficient treatments of VOCs after removal from the ground. The processes developed for aboveground destruction of the contaminants could be modified for example, for use in a recirculation well. Three TTPs were identified that investigated the use of electric or steam heating to aid in the recovery of VOCs from the subsurface. These TTPs were directed at in situ use of the technology. Seven TTPs were directed at the removal of radioactive nuclides, while one TTP was directed at stabilization. The stabilization TTP used grouting to immobilize contaminants. One Cooperative Research and Development (CRADA) was active to evaluate and develop methods for removal of paramagnetic actinides. Four TTPs were focused on removal of actinides by leaching or soil washing. Adsorption and reactive/adsorbent barriers were the subjects of the last two TTPs.

Basic research in support of applied environmental restoration and waste management is sponsored by the DOE Office of Energy Research (OER). Research needs were defined by the Office of Environmental Restoration (ER) and grouped into five areas: (1) environmental transport and transformations; (2) advanced sampling, characterization, and monitoring methods; (3) new remediation technologies; (4) performance assessment; and (5) health and environmental effects. Within the new remediation technologies area, basic research was identified that was deemed "... necessary to improve the effectiveness and/or reduce the cost associated with environmental remediation." The report went on to state that "... major gaps in fundamental knowledge exist for remediating DOE wastes." The topical areas of research needs were: (1) inactive facilities decontamination and decommissioning, (2) concentrated wastes, (3) treatment of contaminated environments, and (4) containment of contaminated environments. Within the area of treatment of contaminated environments, the research needs included: in situ biosorption; in situ scavenging colloids; in situ supercritical fluid processes; in situ heating; and in situ oxidation.

In addition to research sponsored within the DOE OTD of OER, applied research and demonstration activities are ongoing at various DOE sites with support from ER. Information describing these activities was not readily available at the time of this writing. 
EPA conducts and funds significant research and development activities in environmental remediation using physical and chemical means. The Office of Exploratory Research and the Risk Reduction Engineering Laboratory (RREL) were identified as conducting research of in situ treatment using physical and chemical processes. Ongoing research projects in the Office of Exploratory Research were identified in the following areas: solubilization of PAHs using surfactants, prevention of well-aquifer interface plugging by bacteria/precipitate, destruction of chlorinated hydrocarbons, removal of heavy metals, transport of heavy metals, and oxidation of organics using supercritical fluid oxidation. A majority of the funded projects investigated removal of heavy metals from the environment.

Research under the RREL Superfund Innovative Technology (SITE) program occur under two different subprograms: the demonstration program and the emerging technology program. Ongoing research in the demonstration program identified as being an in situ process or having the potential to be used as an in situ process included: immobilization of metals using reduction, enhanced volatilization using physical processes, fracturing for improving subsurface mass transfer, destruction of VOC, and the CROWTM process. Ongoing research in the emerging technology program applicable to the developing in situ program includes: destruction of organic contaminants using oxidation and catalytic processes, fracturing, the CROW ${ }^{\mathrm{TM}}$ process, and the use of electric or acoustic fields for removal of heavy metals.

The United States Air Force (USAF) has active R\&D programs in environmental remediation. Research efforts include measurement of subsurface mass transfer; soilvapor extraction (including ambient and soil heating techniques for shallow and deep VOC contamination); immobilization of heavy metals; contaminant destruction using catalytic, ultraviolet/oxidation, advanced oxidation methods, ozonation, or photocatalytic film destruction; an advanced microporous membrane system for removing VOCs from water; and a preliminary guidance manual for DNAPLs.

The United States Army (Army) has active R\&D programs in environmental remediation. Efforts that are ongoing include stabilization of metals in sediments and soils, treatment and removal of organic compounds from sediments, investigation of leaching processes, modeling of seepage and groundwater flow, and evaluation and development of thermal stripping techniques for remediation of hydrocarbon- and solvent-contaminated soils.

The Electric Power Research Institute (EPRI) funds research for remediation of soils contaminated with PAHs and fuels. EPRI published a report, EPRI GS-7554, detailing its efforts to develop remediation techniques for $\mathrm{PAH}$ contaminated soils entitled Assessment of Selected Technologies for Remediation of Manufactured Gas Plant Sites. Prepared by IT Corporation of Knoxville, Tennessee, the report was published in October 1991. Another report was also published detailing EPRI efforts to develop remediation techniques for remediation of underground storage tanks. The report, EPRI CS-5261, is entitled Remedial Technologies for Leaking Underground Storage Tanks. This report, published in 1988, is presently being revised.

EPRI report GS-7554 evaluates a number of physical and chemical treatments for treating PAH contamination. The report lists regulatory, transportation, and treatment methods, including the level of development for each technology (bench, pilot, demonstration, in situ, ex situ). Physical/chemical treatments evaluated include chemical oxidation using peroxides/ozone, chlorine-based oxidation methods, chemical reduction, hydrolysis, 
photochemical treatments, electrochemical treatments, and wet-air oxidation. Soil extraction technologies are also discussed, including aqueous soil-washing methods, froth floatation methods, hydrogravimetric separations, acid and base soil-washing, sorbent extraction, electrokinetics, non-aqueous soil washing methods, steam flushing, thermal desorption, and in situ thermal desorption. Stabilization methods are also discussed including cementing; the use of lime, fly ash and lime, silicates, clays and sorbents, and organic binders; chemical precipitation; and vitrification.

The Gas Research Institute (GRI) funds R\&D programs in remediation of PAHcontaminated sites. Its major research effort is bioremediation with physical/chemical treatment for enhancement of the bioremediation process. Physical/chemical treatment interests include the CROW ${ }^{\mathrm{TM}}$ process, UV/oxidation for destruction of metal cyanide complexes, and Fenton's reagent for degradation of hydrocarbons. GRI has also compiled a major document describing applicable processes for treatment of manufactured gas plant sites: Management of Manufactured Gas Plant Sites, Vol. 1-4, Remediation Technologies, Inc.

The National Science Foundation (NSF) funds research through competitive grants and through research centers. NSF does not have an active program in environmental restoration, although a small amount of work is conducted under the engineering subprogram.

Eleven federal agencies have small business innovative research (SBIR) programs. The SBIR programs are funded at $1.25 \%$ of an agency's extramural R\&D budget (if the R\&D budget is greater than $\$ 100$ million) as required by the Small Business Innovation Development Act, Public Law 97-219. Of the different programs surveyed, only EPA has an active program for specifically developing in situ remediation techniques. Of the three awards for 1992 made by the EPA program, In Situ Treatment of Hazardous and Toxic Waste at Superfund Sites, two awards of approximately $\$ 5,000$ and $\$ 45,000$ were made for projects related to biodegradation, while the third award $(\$ 50,000)$ was made for a catalytic process for dehalogenation of chlorinated aromatic compounds. DOE has an active program for developing monitors and characterization methods for terrestrial contamination, although there is no explicit program for in situ remediation. DOE made two awards in their program, Advanced Characterization and Monitoring Methods for Subsurface Terrestrial Contamination, of approximately $\$ 50,000$ to each of two small businesses during 1992.

The following tables list selected DOE- and EPA-funded R\&D programs. 
Table B.1. U.S. DOE funded physical/chemical research for in situ use or applicable for in situ use.

\begin{tabular}{|c|c|c|c|c|}
\hline Title & TTP number & Location & $\begin{array}{l}\text { Funding: } \\
F Y, \$\end{array}$ & Comments \\
\hline $\begin{array}{l}\text { Groundwater and } \\
\text { Cost Modeling at } \\
\text { SRI Integrated } \\
\text { Demonstration }\end{array}$ & AL221001 & LANL & $\begin{array}{l}\text { FY92, 460K } \\
\text { FY93, 605K } \\
\text { FY94, 605K }\end{array}$ & $\begin{array}{l}\text { Air stripping and } \\
\text { bioremediation }\end{array}$ \\
\hline $\begin{array}{l}\text { SRS } \\
\text { Demonstration: } \\
\text { Remediation } \\
\text { Tasks }\end{array}$ & SR121106 & WSRC & $\begin{array}{l}\text { FY92, 2090K } \\
\text { FY93, 2090K } \\
\text { FY94, 2450K }\end{array}$ & $\begin{array}{l}\text { Air stripping and } \\
\text { bioremediation }\end{array}$ \\
\hline $\begin{array}{l}\text { Arid Integrated } \\
\text { Demonstration } \\
\text { EPA IAG }\end{array}$ & HQ31003 & & $\begin{array}{l}\text { FY92, 0K } \\
\text { FY93, 283K } \\
\text { FY94, 0K }\end{array}$ & $\begin{array}{l}\text { Soil stripping and } \\
\text { bioremediation }\end{array}$ \\
\hline $\begin{array}{l}\text { Utility Industry } \\
\text { Directional } \\
\text { Drilling }\end{array}$ & AL221103 & SNL/SRS & $\begin{array}{l}\text { FY92, 300K } \\
\text { FY93, 300K } \\
\text { FY94, 300K }\end{array}$ & $\begin{array}{l}\text { Joint project with } \\
\text { Ditch Witch, Inc. }\end{array}$ \\
\hline $\begin{array}{l}\text { Drilling } \\
\text { Technology } \\
\text { Development }\end{array}$ & RL421103 & WHC & $\begin{array}{l}\text { FY92, 1000K } \\
\text { FY93, 1700K } \\
\text { FY94, 180K }\end{array}$ & $\begin{array}{l}\text { Horizontal wells at } \\
\text { arid sites }\end{array}$ \\
\hline $\begin{array}{l}\text { SRS Integrated } \\
\text { Demonstration; } \\
\text { Directional } \\
\text { Drilling }\end{array}$ & SR121101 & WSRC & $\begin{array}{l}\text { FY92, 975K } \\
\text { FY93, 900K } \\
\text { FY94, 1000K }\end{array}$ & $\begin{array}{l}\text { Evaluation of } \\
\text { horizontal well } \\
\text { drilling equipment } \\
\text { and techniques } \\
\text { from } \\
\text { petrochemical, } \\
\text { pipeline, and small } \\
\text { utility sources }\end{array}$ \\
\hline $\begin{array}{l}\text { Integrated } \\
\text { Demonstration for } \\
\text { Cleanup of } \\
\text { Organics in Soils } \\
\text { at Non-Arid Sites: } \\
\text { Off Gas Treatment }\end{array}$ & SR121107 & WSRC & $\begin{array}{l}\text { FY92, 550K } \\
\text { FY93, 675K } \\
\text { FY94, 800K }\end{array}$ & $\begin{array}{l}\text { Catalytic, } \\
\text { bioremediation, } \\
\text { thermal, } \\
\text { electrochemical, } \\
\text { and carbon } \\
\text { regeneration } \\
\text { systems }\end{array}$ \\
\hline $\begin{array}{l}\text { Volatile Organic } \\
\text { Carbon } \\
\text { Recycle/Recovery }\end{array}$ & ID 121114 & EG\&G & $\begin{array}{l}\text { FY92,325K } \\
\text { FY93, 35K } \\
\text { FY94, 0K }\end{array}$ & \\
\hline
\end{tabular}


Table B.1. U.S. DOE funded physical/chemical research for in situ use or applicable for in situ use (continued).

\begin{tabular}{|c|c|c|c|c|}
\hline Title & TTP number & Location & $\begin{array}{l}\text { Funding: } \\
F Y, \$\end{array}$ & Comments \\
\hline $\begin{array}{l}\text { Destruction of } \mathrm{CCl}_{4} \\
\text { and } \mathrm{CHCl}_{3} \text { by Steam } \\
\text { Reforming }\end{array}$ & $\begin{array}{l}\text { AL221106 } \\
\text { LANL }\end{array}$ & LANL & $\begin{array}{l}\text { FY92, 150K } \\
\text { FY93, 47K } \\
\text { FY94, 50K }\end{array}$ & \\
\hline $\begin{array}{l}\text { High Energy Corona } \\
\text { for Destruction of } \\
\text { VOCs in Off Gas }\end{array}$ & RL321101 & PNL & $\begin{array}{l}\text { FY92, 80K } \\
\text { FY93, 220K } \\
\text { FY94, OK }\end{array}$ & \\
\hline $\begin{array}{l}\text { VOC Offgas } \\
\text { Membrane Separation }\end{array}$ & RL42104 & PNL & $\begin{array}{l}\text { FY92, 0K } \\
\text { FY93, 75K } \\
\text { FY94, 0K }\end{array}$ & $\begin{array}{l}\text { Membrane } \\
\text { separation }\end{array}$ \\
\hline In Situ Heating & SR131001 & SRTC & $\begin{array}{l}\text { FY92, 0K } \\
\text { FY93, 750K } \\
\text { FY94, 600K }\end{array}$ & $\begin{array}{l}\text { Evaluation of two } \\
\text { technologies }\end{array}$ \\
\hline $\begin{array}{l}\text { Thermal Enhanced } \\
\text { Vapor Extraction } \\
\text { System }\end{array}$ & AL221121 & SNL & $\begin{array}{l}\text { FY92, 500K } \\
\text { FY93, 200K } \\
\text { FY94, 350K }\end{array}$ & Electric heating \\
\hline $\begin{array}{l}\text { Dynamic } \\
\text { Underground } \\
\text { Stripping } \\
\text { Demonstration Project }\end{array}$ & SF211104 & LLNL & $\begin{array}{l}\text { FY92, 3045K } \\
\text { FY93, 100K } \\
\text { FY94, 0K }\end{array}$ & $\begin{array}{l}\text { Electric and steam } \\
\text { heating }\end{array}$ \\
\hline $\begin{array}{l}\text { Six-Phase Soil } \\
\text { Heating for Enhanced } \\
\text { Removal of } \\
\text { Contaminants }\end{array}$ & RL331003 & PNL & $\begin{array}{l}\text { FY92, 800K } \\
\text { FY93, 780K } \\
\text { FY94, 140K }\end{array}$ & $\begin{array}{l}\text { Electric heating of } \\
\text { soils }\end{array}$ \\
\hline $\begin{array}{l}\text { In Situ Containment } \\
\text { and Stabilization of } \\
\text { Buried Waste }\end{array}$ & $\mathrm{CH} 321101$ & ANL & $\begin{array}{l}\text { FY92, 150K } \\
\text { FY93, 200K } \\
\text { FY94, 725K }\end{array}$ & Grouting \\
\hline $\begin{array}{l}\text { Magnetic Separation } \\
\text { CRADA }\end{array}$ & AL124103 & LANL & $\begin{array}{l}\text { FY92, 100K } \\
\text { FY93, 187K } \\
\text { FY94, 200K }\end{array}$ & $\begin{array}{l}\text { Removal of } \\
\text { paramagnetic } \\
\text { actinides }\end{array}$ \\
\hline $\begin{array}{l}\text { Soil Contaminant } \\
\text { Extraction/ } \\
\text { Leaching }\end{array}$ & SR121105 & WSRC & $\begin{array}{l}\text { FY92, 120K } \\
\text { FY93, 150K } \\
\text { FY94, 0K }\end{array}$ & $\begin{array}{l}\text { Leaching of } \\
\text { uranium }\end{array}$ \\
\hline
\end{tabular}


Table B.1. U.S. DOE funded physical/chemical research for in situ use or applicable for in situ use (continued).

\begin{tabular}{|c|c|c|c|c|}
\hline Title & TTP number & Location & $\begin{array}{l}\text { Funding: } \\
\text { FY, \$ }\end{array}$ & Comments \\
\hline $\begin{array}{l}\text { In Situ Chemical } \\
\text { Treatment: } \\
\text { Evaluation of the In } \\
\text { Situ Chemical } \\
\text { Treatment Approach } \\
\text { for Remediation of } \\
\text { Contaminated Soils } \\
\text { and Groundwater }\end{array}$ & RL431001 & $\overline{\mathrm{WHC}}$ & $\begin{array}{l}\text { FY92, 170K } \\
\text { FY93, 170K } \\
\text { FY94, 300K }\end{array}$ & $\begin{array}{l}\text { Development of } \\
\text { new radioactive } \\
\text { nuclide and metal } \\
\text { chemical treatment }\end{array}$ \\
\hline $\begin{array}{l}\text { Selective Extraction/ } \\
\text { Leaching }\end{array}$ & OR121105 & MMES & $\begin{array}{l}\text { FY92, } 250 \mathrm{~K} \\
\text { FY93, 450K } \\
\text { FY94, 0K }\end{array}$ & $\begin{array}{l}\text { Carbonate and } \\
\text { citrate soil washing }\end{array}$ \\
\hline $\begin{array}{l}\text { Selective Extraction/ } \\
\text { Leaching }\end{array}$ & AL121121 & LANL & $\begin{array}{l}\text { FY92, 260K } \\
\text { FY93, 400K } \\
\text { FY94, 0K }\end{array}$ & $\begin{array}{l}\text { Use of chelation, } \\
\text { oxidation, and } \\
\text { reduction to remove } \\
\text { uranium }\end{array}$ \\
\hline $\begin{array}{l}\text { Chemically Enhanced } \\
\text { Barriers/Vadose Zone }\end{array}$ & RL331002 & PNL & $\begin{array}{l}\text { FY92-100K } \\
\text { FY93-760K } \\
\text { FY94-500K }\end{array}$ & $\begin{array}{l}\text { Incorporation of } \\
\text { adsorbent or reagent } \\
\text { into or next to } \\
\text { barrier }\end{array}$ \\
\hline $\begin{array}{l}\text { Development of High } \\
\text { Capacity Selective } \\
\text { Sequestering Agents } \\
\text { (Solid Sorbents for } \\
\text { Selective Separation } \\
\text { of Radioactive } \\
\text { Nuclides) }\end{array}$ & RL321701 & PNL & $\begin{array}{l}\text { FY92-0K } \\
\text { FY93-1000K } \\
\text { FY94-0K }\end{array}$ & \\
\hline $\begin{array}{l}\text { NAPL Remediation } \\
\text { Using Foam }\end{array}$ & $\mathrm{CH} 241003$ & ANL & FY94, 250K & $\begin{array}{l}\text { Use of foams to } \\
\text { release and mobilize } \\
\text { NAPLs }\end{array}$ \\
\hline $\begin{array}{l}\text { Remediation of } \\
\text { DNAPL in Low } \\
\text { Permeability Media }\end{array}$ & OR131007 & ORNL & FY94, 536K & $\begin{array}{l}\text { Testing and } \\
\text { evaluation of in situ } \\
\text { technologies for } \\
\text { DNAPL remediation }\end{array}$ \\
\hline $\begin{array}{l}\text { Mixed Contamination } \\
\text { in Groundwater }\end{array}$ & OR141002 & ORNL & FY94,310K & $\begin{array}{l}\text { Evaluation of } \\
\text { horizontal wells for } \\
\text { groundwater } \\
\text { recirculation and } \\
\text { VOC and } \\
\text { radionuclide } \\
\text { removal }\end{array}$ \\
\hline
\end{tabular}


Table B.2. EPA Office Of Exploratory Research for 1991 and 1992.

\begin{tabular}{|c|c|c|c|}
\hline Title & $\begin{array}{l}\text { Primary } \\
\text { investigator }\end{array}$ & $\begin{array}{c}\text { Project } \\
\text { duration }\end{array}$ & Funding \\
\hline $\begin{array}{l}\text { Solubilization of Polycyclic } \\
\text { Aromatic Hydrocarbons } \\
\text { Contaminants in Soil-Water Systems } \\
\text { Using Surface Active Agents }\end{array}$ & R. Luthy & 2 years & $\$ 200 \mathrm{~K}$ \\
\hline $\begin{array}{l}\text { Problem of Soil Plugging Identified } \\
\text { and Mitigated }\end{array}$ & P. R. Jaffe & & \\
\hline Dechlorination of PCE and PCBs & T. M. Vogel & & \\
\hline $\begin{array}{l}\text { Integration of Chemical and } \\
\text { Biological Techniques for Removal } \\
\text { of Heavy Metals from Contaminated } \\
\text { Soils and Aquifers }\end{array}$ & M. L. Brusseau & 2 Years & $\$ 170 \mathrm{~K}$ \\
\hline $\begin{array}{l}\text { Toxic Trace Metals in Anoxic } \\
\text { Aqueous Systems }\end{array}$ & J. O. Leckie & 3 Years & $\$ 420 \mathrm{~K}$ \\
\hline $\begin{array}{l}\text { A Thermodynamic Model of Metal } \\
\text { Binding by Humic Substances }\end{array}$ & F. M. M. Morel & 3 Years & $\$ 330 \mathrm{~K}$ \\
\hline $\begin{array}{l}\text { In-Situ Chemical Enhancement for } \\
\text { Remediation of Chromium } \\
\text { Contaminated Aquifers Using Sulfate } \\
\text { Extraction }\end{array}$ & C. D. Palmer & 2 Years & $\$ 200 \mathrm{~K}$ \\
\hline $\begin{array}{l}\text { Removal of Heavy Metals from } \\
\text { Groundwater Using Magnetic } \\
\text { Chitosan Beads }\end{array}$ & J.D. Way & 2 Years & $\$ 200 \mathrm{~K}$ \\
\hline $\begin{array}{l}\text { Inorganic Chemically Active Beads } \\
\text { for Heavy Metals Removal at } \\
\text { Superfund Sites }\end{array}$ & L. L. Tarlarides & 2 Years & $\$ 200 \mathrm{~K}$ \\
\hline $\begin{array}{l}\text { Removal of Lead from Superfund } \\
\text { Sites Using Soil Flushing }\end{array}$ & M. Matsumoto & 2 Years & $\$ 200 \mathrm{~K}$ \\
\hline $\begin{array}{l}\text { Innovative Technologies for } \\
\text { Removal of Heavy Metals at } \\
\text { Superfund Sites }\end{array}$ & J O'Shaughnessy & 2 Years & $\$ 200 \mathrm{~K}$ \\
\hline $\begin{array}{l}\text { Treatment of Hazardous Chemicals } \\
\text { by Oxidation in Supercritical Water }\end{array}$ & J.W. Tester & 2 Years & $\$ 110 \mathrm{~K}$ \\
\hline
\end{tabular}


Table B.3. SITE program demonstrations for 1991 and 1992.

\begin{tabular}{|c|c|c|c|}
\hline Technology & Technology description & $\begin{array}{l}\text { Target contaminants } \\
\text { and media }\end{array}$ & $\begin{array}{l}\text { Primary } \\
\text { investigator }\end{array}$ \\
\hline $\begin{array}{l}\text { Electrochemical } \\
\text { in situ chromate } \\
\text { reduction and } \\
\text { heavy-metal } \\
\text { immobilization }\end{array}$ & $\begin{array}{l}\text { Immobilization of } \\
\text { chromate and other heavy } \\
\text { metals in groundwater } \\
\text { using electrical reduction }\end{array}$ & $\begin{array}{l}\text { Heavy metals in } \\
\text { flowing } \\
\text { groundwater }\end{array}$ & $\begin{array}{l}\text { Andco } \\
\text { Environmental } \\
\text { Processes, Inc. }\end{array}$ \\
\hline $\begin{array}{l}\text { Hrubout } \circledast \\
\text { process }\end{array}$ & $\begin{array}{l}\text { Injection of } 1200^{\circ} \mathrm{F} \text { air } \\
\text { into soil }\end{array}$ & VOCs and SVOCs & $\begin{array}{l}\text { Hrubetz } \\
\text { Environmental } \\
\text { Services, Inc. }\end{array}$ \\
\hline $\begin{array}{l}\text { Radio- } \\
\text { frequency } \\
\text { heating }\end{array}$ & $\begin{array}{l}\text { Volatilization of } \\
\text { contaminants using } \\
\text { electromagnetic energy } \\
\text { with treatment of resulting } \\
\text { vapors }\end{array}$ & $\begin{array}{l}\text { VOCs and SVOCs } \\
\text { in the vadose zone }\end{array}$ & $\begin{array}{l}\text { Illinois Institute } \\
\text { of Technology } \\
\text { Research } \\
\text { Institute/ } \\
\text { Halliburton } \\
\text { NUS }\end{array}$ \\
\hline $\begin{array}{l}\text { Steam-enhanced } \\
\text { recovery } \\
\text { process }\end{array}$ & $\begin{array}{l}\text { Injection of steam } \\
\text { followed by treatment of } \\
\text { aquifer fluids }\end{array}$ & VOCs and SVOCs & $\begin{array}{l}\text { Hughes } \\
\text { Environmental } \\
\text { Systems, Inc. }\end{array}$ \\
\hline $\begin{array}{l}\text { In situ steam- } \\
\text { enhanced } \\
\text { extraction }\end{array}$ & $\begin{array}{l}\text { Use of vertical wells to } \\
\text { inject steam and extract } \\
\text { VOCs and SVOCs }\end{array}$ & $\begin{array}{l}\text { VOC and SVOC } \\
\text { stripping in vadose } \\
\text { and aquifer zones }\end{array}$ & $\begin{array}{l}\text { Udell } \\
\text { Technologies, } \\
\text { Inc. }\end{array}$ \\
\hline $\begin{array}{l}\text { In situ steam } \\
\text { and air stripping }\end{array}$ & $\begin{array}{l}\text { Soil mixing with steam } \\
\text { and air injection for } \\
\text { removing VOCs }\end{array}$ & $\begin{array}{l}\text { VOC and SVOC in } \\
\text { soils to } 27 \mathrm{ft}\end{array}$ & $\begin{array}{l}\text { NOVATERRA, } \\
\text { Inc. (formerly } \\
\text { Toxic } \\
\text { Treatment, Inc.) }\end{array}$ \\
\hline $\begin{array}{l}\text { Hydraulic } \\
\text { fracturing }\end{array}$ & $\begin{array}{l}\text { Hydraulic fracturing using } \\
\text { a viscous fluid with sand. } \\
\text { After initiation of fracture, } \\
\text { an enzyme is added that } \\
\text { reduces the fluid viscosity } \\
\text { and leaves the sand in } \\
\text { place to preserve the } \\
\text { fracture }\end{array}$ & $\begin{array}{l}\text { VOC stripping and } \\
\text { bioremediation in } \\
\text { vadose and aquifer } \\
\text { zones }\end{array}$ & $\begin{array}{l}\text { RREL and the } \\
\text { University of } \\
\text { Cincinnati }\end{array}$ \\
\hline
\end{tabular}


Table B.3. SITE program demonstrations for 1991 and 1992 (continued).

\begin{tabular}{|c|c|c|c|}
\hline Technology & Technology description & $\begin{array}{l}\text { Target contaminants } \\
\text { and media }\end{array}$ & $\begin{array}{l}\text { Primary } \\
\text { investigator }\end{array}$ \\
\hline $\begin{array}{l}\text { Pneumatic } \\
\text { fracturing, } \\
\text { extraction, and } \\
\text { catalytic } \\
\text { oxidation }\end{array}$ & $\begin{array}{l}\text { Pneumatic fracturing with } \\
\text { hot gas injection; used in } \\
\text { DNAPL-contaminated } \\
\text { aquifers }\end{array}$ & $\begin{array}{l}\text { DNAPL in low } \\
\text { permeability } \\
\text { formations }\end{array}$ & $\begin{array}{l}\text { Accutech } \\
\text { Remedial } \\
\text { Systems, Inc. }\end{array}$ \\
\hline $\begin{array}{l}\text { In situ vacuum } \\
\text { extraction }\end{array}$ & $\begin{array}{l}\text { Removal of subsurface } \\
\text { fluids (water and air) for } \\
\text { aboveground treatment }\end{array}$ & $\begin{array}{l}\text { VOC stripping and } \\
\text { bioremediation in } \\
\text { vadose and aquifer } \\
\text { zones }\end{array}$ & Terra Vac, Inc. \\
\hline $\begin{array}{l}\text { Subsurface } \\
\text { volatilization } \\
\text { and ventilation } \\
\text { system }\end{array}$ & $\begin{array}{l}\text { Network of injection and } \\
\text { extraction wells strip } \\
\text { contaminants from the } \\
\text { subsurface using air }\end{array}$ & $\begin{array}{l}\text { VOCs in aquifer or } \\
\text { vadose zones }\end{array}$ & $\begin{array}{l}\text { Billings and } \\
\text { Associates, Inc. }\end{array}$ \\
\hline $\begin{array}{l}\text { Ultraviolet } \\
\text { radiation and } \\
\text { oxidation }\end{array}$ & $\begin{array}{l}\text { Oxidation of toxic organic } \\
\text { compounds }\end{array}$ & VOCs and SVOCs & $\begin{array}{l}\text { Ultrox } \\
\text { Resources } \\
\text { Conservation } \\
\text { Co. }\end{array}$ \\
\hline $\begin{array}{l}\text { Contaminated } \\
\text { Recovery of } \\
\text { Oily Wastes } \\
(\text { CROWTM })\end{array}$ & $\begin{array}{l}\text { Adapted secondary oil } \\
\text { recovery process }\end{array}$ & $\begin{array}{l}\text { Oily contaminants } \\
\text { in the vadose zone } \\
\text { and aquifer }\end{array}$ & $\begin{array}{l}\text { Western } \\
\text { Research } \\
\text { Institute }\end{array}$ \\
\hline
\end{tabular}


Table B.4. Emerging Technology R\&D for 1991 and 1992.

\begin{tabular}{|c|c|c|c|}
\hline Technology & Technology description & $\begin{array}{l}\text { Target contaminants } \\
\text { and media }\end{array}$ & $\begin{array}{l}\text { Primary } \\
\text { investigator }\end{array}$ \\
\hline $\begin{array}{l}\text { Reductive } \\
\text { photo- } \\
\text { dechlorination } \\
\text { treatment }\end{array}$ & $\begin{array}{l}\text { Use of heat and ultraviolet } \\
\text { radiation to remove } \\
\text { halogens from pollutant } \\
\text { molecules }\end{array}$ & Chlorinated VOCs & $\begin{array}{l}\text { M. L. Energia, } \\
\text { Inc. }\end{array}$ \\
\hline $\begin{array}{l}\mathrm{TiO}_{2} \\
\text { photocatalytic } \\
\text { air treatment }\end{array}$ & $\begin{array}{l}\text { Photocatalytic treatment } \\
\text { for VOCs and SVOCs }\end{array}$ & $\begin{array}{l}\text { Vapors removed } \\
\text { from soil }\end{array}$ & $\begin{array}{l}\text { Nutech } \\
\text { Environmental }\end{array}$ \\
\hline $\begin{array}{l}\mathrm{TiO}_{2} \\
\text { photocatalytic } \\
\text { water treatment }\end{array}$ & $\begin{array}{l}\text { Photocatalytic treatment } \\
\text { for VOCs and SVOCs }\end{array}$ & $\begin{array}{l}\text { Aqueous-phase } \\
\text { contaminants } \\
\text { removed from soil }\end{array}$ & $\begin{array}{l}\text { Nutech } \\
\text { Environmental } \\
\text { (formerly Matrix } \\
\text { Photocatalytic, } \\
\text { Ltd.) }\end{array}$ \\
\hline $\begin{array}{l}\text { Photolytic } \\
\text { oxidation } \\
\text { process }\end{array}$ & $\begin{array}{l}\text { Photolytic oxidation using } \\
\text { a xenon pulsed-plasma } \\
\text { flash lamp }\end{array}$ & $\begin{array}{l}\text { Stripped VOCs and } \\
\text { SVOCs }\end{array}$ & Purus, Inc. \\
\hline $\begin{array}{l}\text { Pneumatic } \\
\text { fracturing and } \\
\text { biodegradation }\end{array}$ & $\begin{array}{l}\text { Fracturing using } \\
\text { compressed air or gases }\end{array}$ & $\begin{array}{l}\text { Organic } \\
\text { contaminants from } \\
\text { vadose zone }\end{array}$ & $\begin{array}{l}\text { Hazardous } \\
\text { Substance } \\
\text { Management } \\
\text { Research Center } \\
\text { at New Jersey } \\
\text { Institute of } \\
\text { Technology }\end{array}$ \\
\hline $\begin{array}{l}\text { Contaminated } \\
\text { Recovery of } \\
\text { Oily Wastes } \\
\left(\text { CROW }^{\mathrm{TM}}\right)\end{array}$ & $\begin{array}{l}\text { Adapted secondary oil } \\
\text { recovery process }\end{array}$ & $\begin{array}{l}\text { Oily contaminants } \\
\text { in the vadose zone } \\
\text { and aquifer }\end{array}$ & $\begin{array}{l}\text { Western } \\
\text { Research } \\
\text { Institute }\end{array}$ \\
\hline $\begin{array}{l}\text { Electrokinetic } \\
\text { remediation }\end{array}$ & $\begin{array}{l}\text { Use of electric and } \\
\text { acoustic field to cause } \\
\text { contaminate migration }\end{array}$ & Heavy metals & $\begin{array}{l}\text { Electrokinetics, } \\
\text { Inc. }\end{array}$ \\
\hline
\end{tabular}

